\title{
Ground Water in the \\ Permafrost Regions of Alaska
}

GEOLOGICAL SURVEY PROFESSIONAL PAPER 696

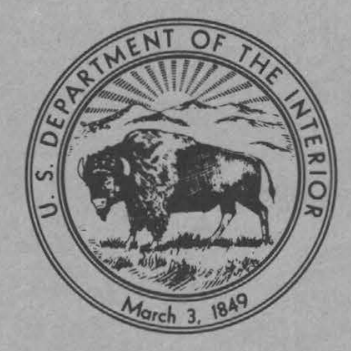




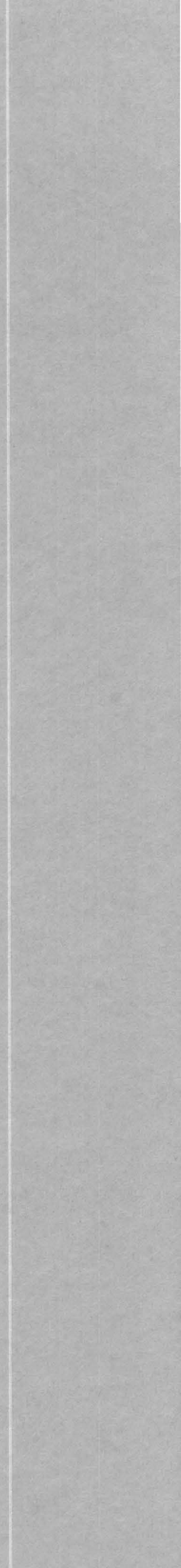




\section{Ground Water in the Permafrost Regions of Alaska}

By JOHN R. WILLIAMS

GEOLOGICAL SURVEY PROFESSIONAL PAPER 696

Ground water in permafrost regions in Alaska occurs according to the same geologic and hydrologic principles prevailing in temperate regions

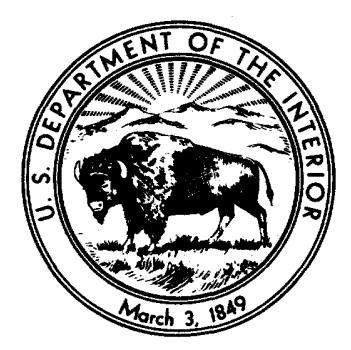




\section{UNITED STATES DEPARTMENT OF THE INTERIOR \\ WALTER J. HICKEL, Secretary}

GEOLOGICAL SURVEY

William T. Pecora, Director 


\section{CONTENTS}

Abstract

Introduction

Previous investigations

Present investigation

Purpose and scope

Basic data

Permafrost

Acknowledgments

Definition and terminology

Origin and history

Distribution and maximum thickness

Regional zonation -

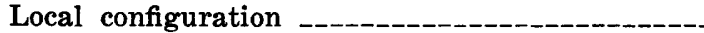

Effect of local climatic differences --_--_-----

Effect of local differences in vegetation -.---

Effect of local topographic differences -..---

Effect of local hydrologic differences

Effect of the ocean

Effect of lakes

Effect of rive

Effect of ground water

Effect of glaciers

Effect of local geologic differences -...--.---

Application of geophysical methods in determining local configuration of permafrost --

Effect of permafrost on ground water

Recharge

Movement -_-_-_--_--

Discharge

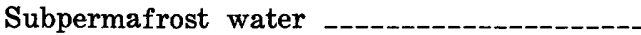

Suprapermafrost water -.-_-_-_-_-_-_-_-

Storage

Occurrence of ground water

Alluvium of river valleys

.Flood-plain and terrace deposits of continuouspermafrost zone

Colville River at Umiat

Shaviovik River valley

Ogotoruk Creek near Cape Thompson -

Selin Creek near Cape Lisburne

Kobuk, Koyukuk, and Chandalar River valleys, southern Brooks Range

Northern Seward Peninsula

Flood-plain and terrace deposits of major valleys of discontinuous-permafrost zone

Lower and middle Koyukuk River valley

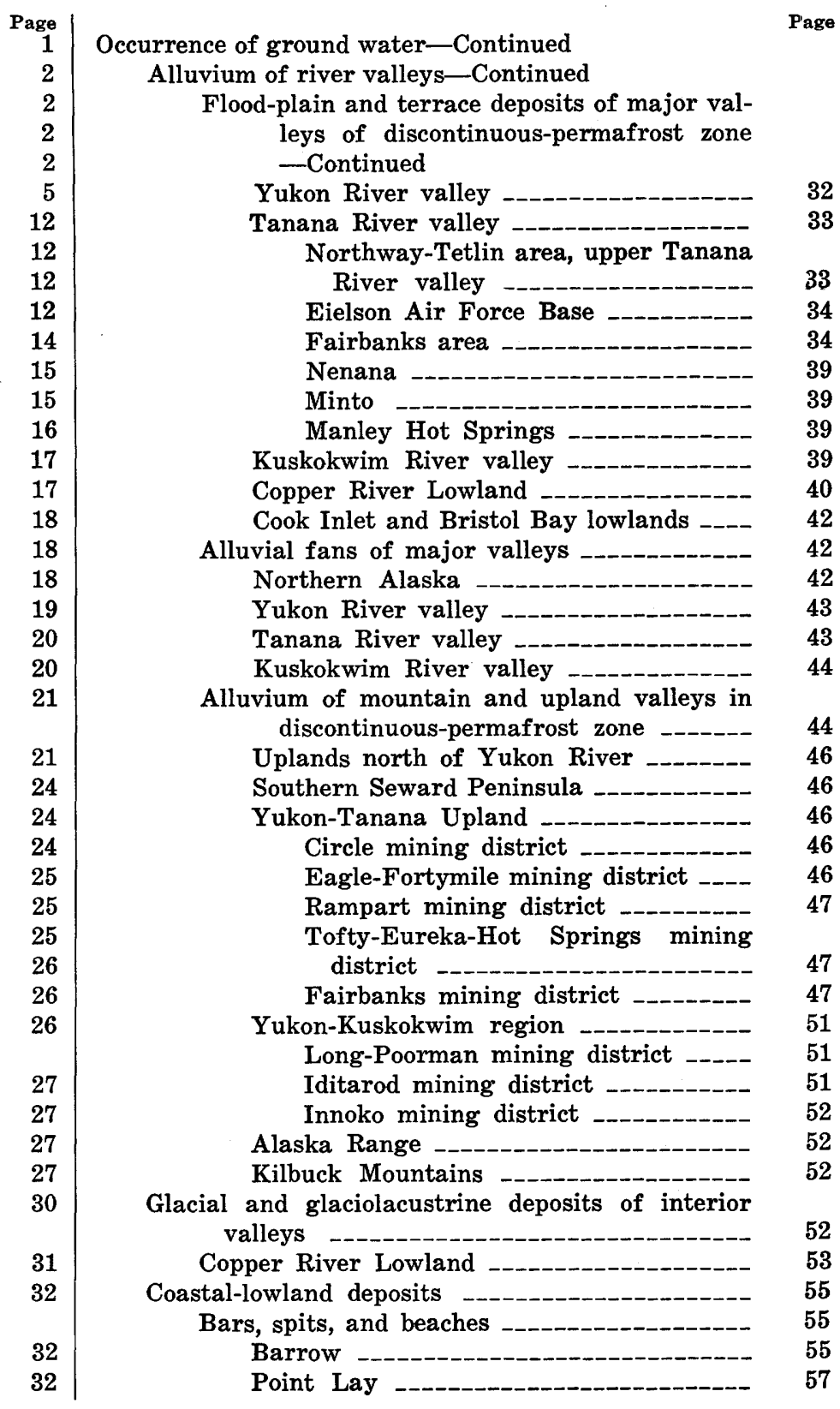

III 
Occurrence of ground water-Continued

Coastal-lowland deposits-Continued

Bars, spits, and beaches-Continued

Point Hope

Kotzebue -

Teller

Point Spencer -

Shaktoolik

Tanunak

Gambell, St. Lawrence Island _.-.--_-_-

Deltas of major rivers

Arctic Coastal Plain

Coastal plain at Nome

Bristol Bay and Cook Inlet lowlands

Bedrock of uplands and mountains

Distribution and thickness of permafrost

Continuous-permafrost zone

Arctic Foothills

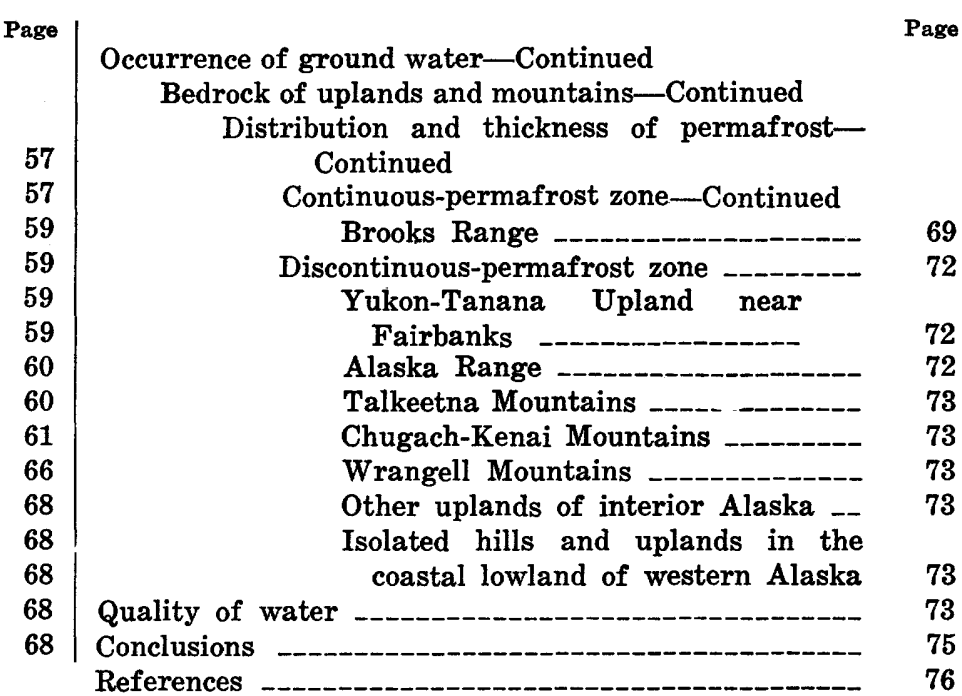

\section{ILLUSTRATIONS}

Figure 1. Map showing distribution of permafrost in the Northern Hemisphere

2. Geologic map showing major geohydrologic environments in the permafrost region

3-8. Maps showing distribution of basic data used in this report -

9. Schematic diagram of ground-temperature change with depth in permafrost regions and in regions having no permafrost

10. Map showing permafrost zones and selected permafrost temperatures --

11. Schematic representation of the effect of bodies of water on configuration of permafrost in the continuouspermafrost zone

12. Map showing depth to base of frozen alluvium in the flood plain and low terraces of part of the Chena River near Fairbanks

13. Well-location map, Umiat area -

14. Generalized geologic map showing distribution and thickness of permafrost in part of the Fairbanks mining district

15. Well-location and geologic sketch map of the Bethel area

16. Geologic map and cross sections of the Glennallen-Gulkana airfield area

17. Well-location map of the Tok area, Tanana River valley
18. Geologic map of Fort Greely area, showing slope of the potentiometric surface and location of selected wells

19. Geologic sections showing permafrost depth through the Happy Creek area and the Dome Creek valley, Fairbanks mining district

20. Hydrologic map of the Isabella Creek valley -

21. Map showing location of test holes in the Barrow area

22. Map showing location of wells and test holes at Kotzebue

23. Cross sections showing relation of permafrost table to topography and to ground-water conditions, Point Spencer spit, Seward Peninsula

24. Map showing location of test wells and test holes, Cape Simpson area

25. Generalized geologic map and cross section of the coastal plain at Nome

\section{TABLES}

TABLE 1. Data on permafrost and ground water in the Colville River valley at Umiat

2. Depth of frozen alluvium in Fairbanks area wells

3. Data on permafrost and ground water in the Arctic Coastal Plain -

4. Data on permafrost and ground water in the Arctic Foothills of the Brooks Range 


\title{
GROUND WATER IN PERMAFROST REGIONS OF ALASKA
}

\author{
By JOHN R. WILLIAMS
}

\begin{abstract}
Although ground water in permafrost regions in Alaska occurs according to the same geologic and hydrologic principles prevailing in temperate regions, subfreezing temperatures result in profound modification of ground-water flow systems. Frozen ground is an impermeable layer which: (1) Restricts recharge, discharge, and movement of ground water, (2) acts as a confining layer, and (3) limits the volume of unconsolidated deposits and bedrock in which liquid water may be stored. Frozen ground in many areas eliminates shallow aquifers and requires that wells be drilled deeper than in similar geologic environments having no permafrost. Although little is known about the effect of permafrost and low water temperatures on quality of ground water, the restricted circulation imposed by permafrost boundaries may increase the concentration of dissolved solids in ground water in some areas. Low ground temperatures above and below permafrost result in ground-water temperatures ranging from $0^{\circ}$ to $4.5^{\circ} \mathrm{C}$ (Celsius). At these temperatures, ground water is more viscous and moves more slowly than in temperate regions.

Permafrost is defined as unconsolidated deposits or bedrock that continuously have had a temperature below $0^{\circ} \mathrm{C}$ for 2 years to thousands of years. It formed when the balance between net heat lost to the atmosphere at the surface and that received from sources within the earth produced negative $\left({ }^{\circ} \mathrm{C}\right)$ temperatures below the depth of maximum summer thawing. The permafrost region in Alaska is divided into: (1) the continuous-permafrost zone, which occupies the area draining to the Arctic Ocean and Chukchi Sea where permafrost is present nearly everywhere to recorded depths of as much as 1,330 feet and (2) the discontinuous-permafrost zone, which occupies much of the area draining to the Bering Sea and Pacific Ocean, where permafrost is at least 600 feet thick locally, but is broken by unfrozen zones that become progressively more extensive southward.
\end{abstract}

Local variations in the thickness, areal extent, and temperature of permafrost depend on variable thermal properties of earth materials and on local differences in the rate of heat flow from within the earth, climate, topography, vegetation, geology, and hydrology. In many places in the discontinuous-permafrost zone, these local variations mask the regional southward decrease in areal extent and thickness and southward increase in permafrost temperature. Knowledge of local variations in permafrost distribution is important in locating ground-water sources and in understanding the hydrology of specific sites.

Ground water occurs above, below, and locally w. jin, permafrost. In the continuous-permafrost zone, the most economically developed sources of water are in unfrozen allu- vium beneath large lakes and rivers. Water is brackish or saline in bedrock beneath permafrost in much of this zone draining to the Arctic Ocean, although fresh water is discharged from springs along faults bounding the limestone of the Lisburne Group in the Brooks Range.

In the discontinuous-permafrost zone, ground water is produced locally from shallow aquifers above permafrost of offshore bars and spits because water within or below the frozen beach deposits is saline. Elsewhere, potential contamination of shallow aquifers makes desirable a source of water beneath the frozen layer. In major valleys and in many smaller upland and mountain valleys, ground water is available in alluvium beneath permafrost or in unfrozen alluvium beneath or adjacent to riverbeds. The frozen layer is generally thicker and areally more extensive beneath terraces than beneath flood plains. The thickness of frozen ground beneath stabilized dunes resting on alluvium is generally greater than that beneath adjacent alluvial deposits not covered by dunes. Limited data suggest that the base of the frozen layer is commonly above the water table beneath the apexes of alluvial and outwash fans in major valleys. In coastal plains and in lowlands underlain by glacial and glaciolacustrine deposits, the complex stratigraphy is paramount in controlling the movement and storage of ground water. In some areas, however, water movement is controlled by impermeable permafrost boundaries; and where the frozen ground extends into bedrock, the unconsolidated deposits are unproductive.

Ground water is obtained from unfrozen bedrock above or beneath permafrost in mountains and uplands and, locally, in some valleys where the unconsolidated deposits are frozen or are too fine grained to yield water. Water is discharged from bedrock at springs that may be either cool or thermal. The hydrology of bedrock aquifers is unknown, but unfrozen zones apparently exist beneath streams, snowbanks, lakes, glaciers, and south-facing slopes. These zones permit water to enter the bedrock. Saline or brackish water is common in marine sedimentary rocks of Mesozoic age in the Arctic Foothills, in the Arctic Coastal Plain, and in the Copper River Lowland. These rocks are apparently the source of saline water in the unconsolidated deposits of part of the Copper River Lowland.

Ground-water supplies are unaffected by permafrost in the following population centers within the permafrost region: Anchorage, Palmer, King Salmon, Dillingham, and Tok. Farther north, at Big Delta, Northway, Fairbanks, McGrath, Bethel, Galena, Tanana, Nenana, and Fort Yukon, the ground-water potential is slightly to seriously affected by permafrost. Ground water is of scant quantity and poor quality, or lacking at Glennallen, Nome, Kotzebue, and many coastal settlements because of a combination of permafrost and unfavorable geologic conditions. 


\section{INTRODUCTION}

Permafrost, in which ground temperature is perennially below $0^{\circ} \mathrm{C}$, lies beneath about 24 percent of the earth's land area (Black, 1954, p. 842), chiefly in Arctic and Subarctic regions (fig. 1) and in the Antarctic. Permafrost also occurs at high altitudes in mountainous parts of the temperate regions. Until about 1930, the forbidding climate of the permafrost regions and their remoteness from population centers had discouraged development of anything but a primitive economy based on fishing, hunting, trapping, and mining. In recent years, however, under the impetus of World War II and the need for land and resources for an expanding world population and more recently the discovery of oil near Prudhoe Bay, the Arctic and Subarctic have been developing rapidly. As development has progressed, the need has increased for safe, dependable, year-round supplies of potable water. River and lake water and snow and ice, once the major sources of water in these regions, are inconvenient to develop and costly to distribute. Some surface water and shallow ground water have a high degree of color and objectionable dissolved organic and mineral constituents. This is not unique to permafrost areas. During the summer months many glacier-fed streams carry suspended sediment. In winter, some streams and lakes yield little or no water and intakes tend to ice over. To avoid some of these problems, the use of ground water has increased as economic growth has justified the expense of drilling wells.

In permafrost regions, as in temperate regions, ground-water occurrence depends primarily on the lithology and structure of the unconsolidated deposits and bedrock and on their hydrologic properties, but this occurrence is subject to certain limitations imposed by permafrost. The major limitations are as follows: (1) Permafrost acts as an impermeable barrier to the movement of ground water, because the pore spaces are generally filled with ice within the zone of saturation. Recharge and discharge of water to and from aquifers beneath permafrost are therefore limited to the unfrozen zones that perforate the permafrost. (2) Permafrost, ranging from a few feet to at least 1,330 feet thick in Alaska, limits the number of sites from which water can be produced from shallow wells. It commonly is necessary to drill to greater depths in permafrost regions than in comparable geologic environments in temperate regions. The near-surface unconsolidated deposits that provide abundant water in some parts of the temperate regions are commonly frozen, and utilization of aquifers of lower yield or poorer quality beneath the permafrost may be necessary. (3) The ground-water temperature ranges from $0^{\circ}$ to $4.5^{\circ} \mathrm{C}$ because of low ground temperature above and below permafrost. In this temperature range, ground water is more viscous and moves more slowly than in temperate regions (Brandon, 1965, $p$. 176-177).

\section{PREVIOUS INVESTIGATIONS}

Although the first knowledge of permafrost reached centers of learning nearly 400 years ago (Sumgin and others, 1940; L. L. Ray, 1952), the first scientific investigations were those of Kotzebue (1821) in Alaska, Richardson $(1841,1854)$ in Canada, and Middendorf $(1848,1867)$ in Siberia. The extensive literature through 1960 on ground water in permafrost regions and a history of permafrost studies are summarized in an annotated bibliography (Williams, 1965). The present report summarizes most of the literature on Alaska and includes material published through April 1964.

\section{PRESENT INVESTIGATION PURPOSE AND SCOPE}

The present investigation was undertaken to provide information for more economical and effective methods of appraising and developing the groundwater resources of Alaska. This investigation was suggested by Cederstrom, Johnston, and Subitzky (1953, p. 26). This report emphasizes the occurrence of ground water in relation to the permafrost and the geologic environment. It cannot cover all aspects of the field of permafrost. Only a generalized, nonmathematical summary of the origin and history of permafrost and a discussion of some of the factors that influence the local configuration of permafrost are given, as an aid to understanding the effect of permafrost on recharge, discharge, movement, and storage of ground water in a given geologic environment. The reader desiring a more sophisticated treatment of permafrost as an aid in planning future investigations of the thermodynamic relations between permafrost and ground water will find some of the references cited in this report helpful.

The material is presented in sections on each of the major geologic environments in the permafrost region (fig. 2). These environments were selected because the geologic conditions controlling the occurrence of ground water are broadly similar from one area to another and hecause the environments are easily identified on topographic or geo- 


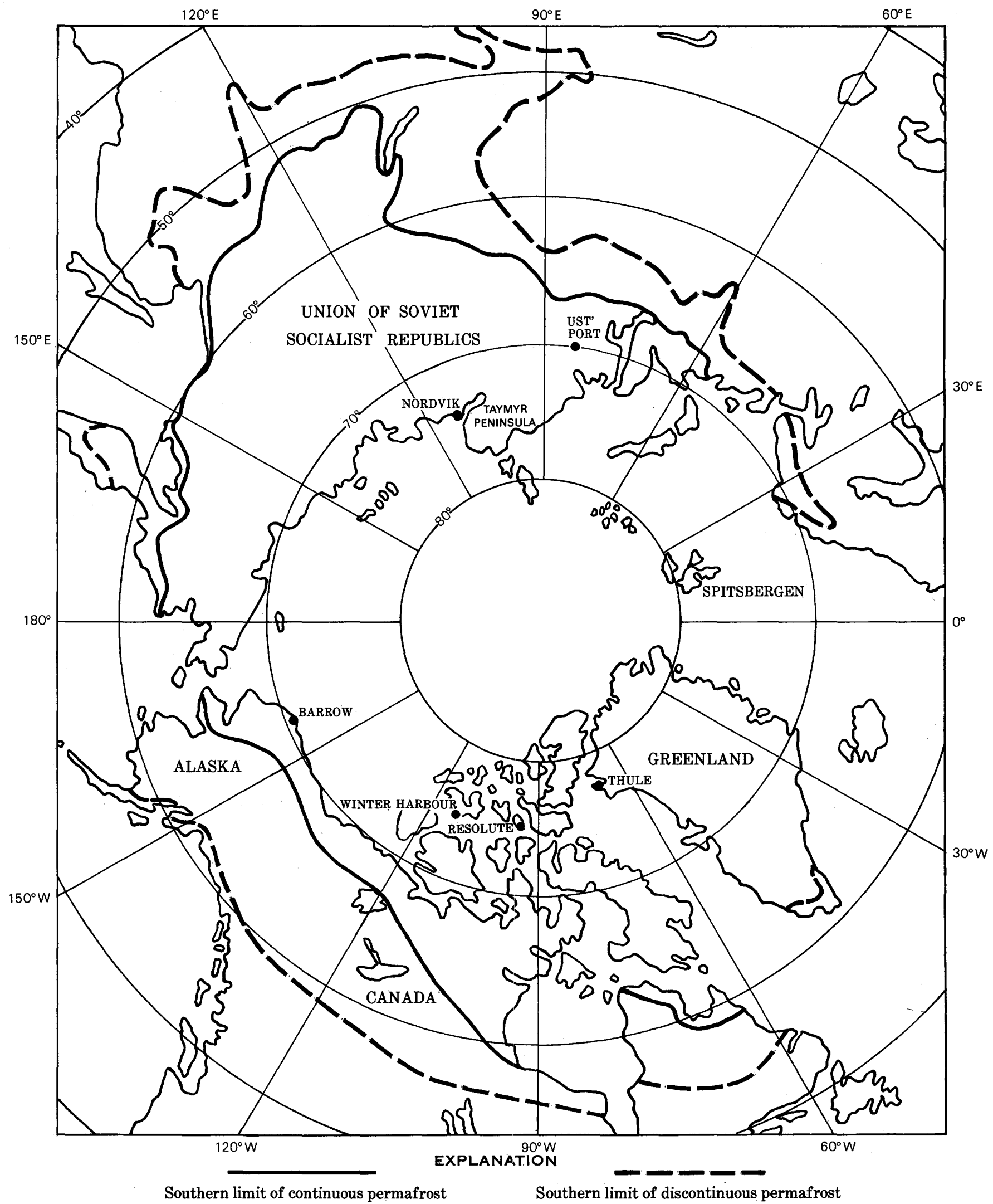

FiguRE 1.-Distribution of permafrost in the Northern Hemisphere. From R. J. E. Brown (1963, fig. 3) with modifications in Alaskan permafrost boundaries. 


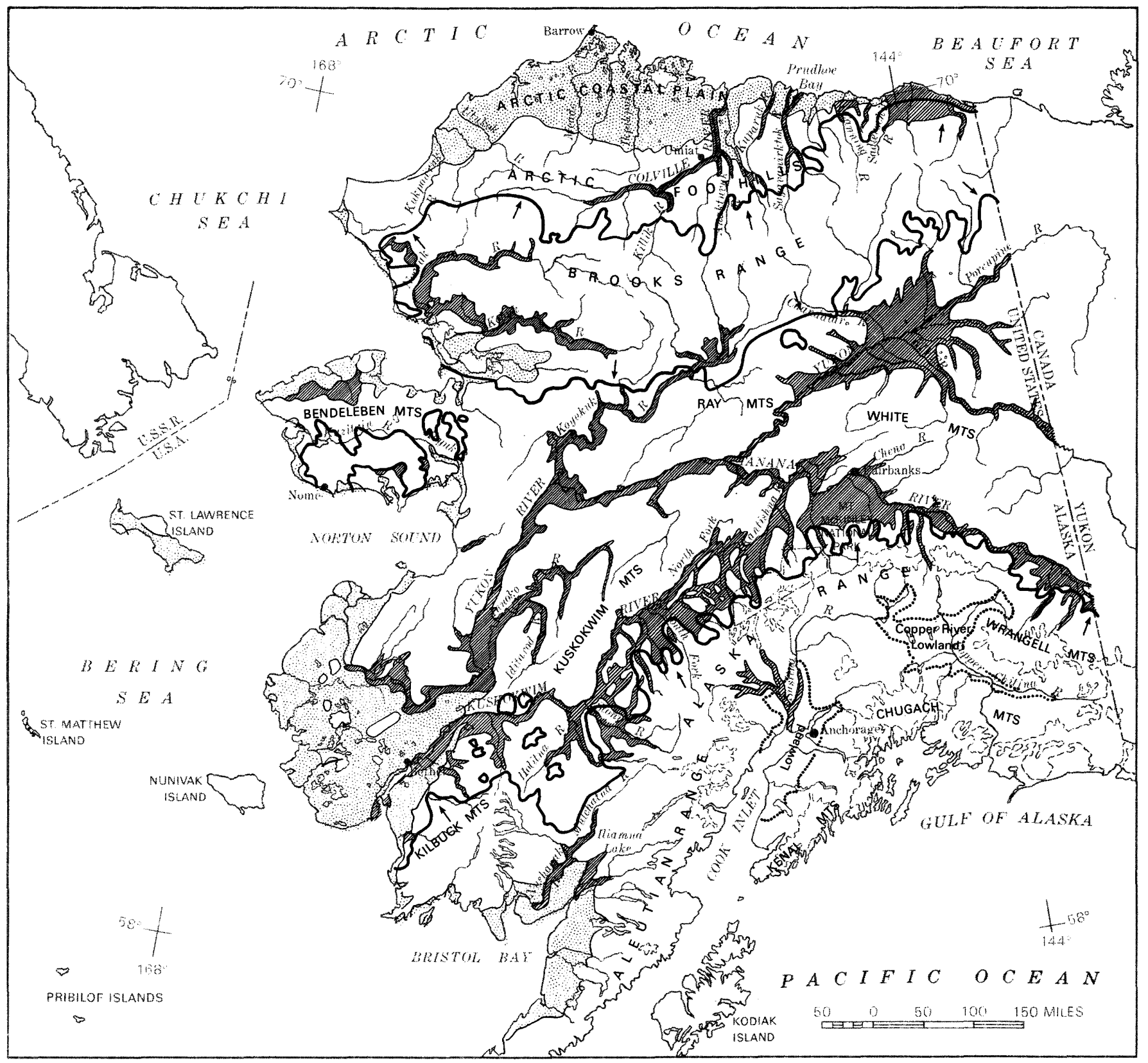

EXPLANATION

\section{7}

Alluvium of major valleys Sand, gravel, and silt of flood plains, low terraces, and alluvial fans

Coastal-lowland deposits Chiefly silt and sand, and subordinate amounts of gravel; includes sand and gravel of bars, beaches and spits, and sand, silt, and gravel of deltas. Within limits of Pleistocene glaciation, include till, glaciomarine, and glacioest tuarine deposit.
Bedrock of mountains and uplands Chiefly bed rock mantled locally by weathered bed rock ribble reworked by frost action, alluvium, and eolian deposits, and, within limit of Pleistocene glaciation, by glacial deposits

Limit of Pleistocene glaciation Unconsolidated deposits with in this limit may include till, sand and gravel, and silt and clay of glacial, glaciolacustrine, glaciomarine, or glacioestuarine origin. (Coulter and others, 1965 )
Cook Inlet and Copper River Lowlands Approximate upper limit of lacustrine silt, clay. sand, gravel. and stony silt and clay of extensive glacial lakes in Copper River Lowland and of glaciolacustrine, glacioestuarine, and glaciomarine deposits in the Cook Inlet lowland

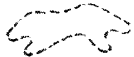

Major glaciers and ice fields

Contact

FIGURE 2.-Geology and major geohydrologic environments in the permafrost region. Modified from Coulter and others (1965) and Karlstrom and others (1964). 
logic maps. They are: (1) Alluvium of flood plains, terraces, and fans in major valleys and of upland and mountain valleys, (2) deposits of coastal lowlands, (3) glacial and glaciolacustrine deposits of the interior valleys, and (4) bedrock of uplands and mountains. Glacial deposits, which are generally interbedded with alluvial or marine deposits, are discussed with those of the coastal and alluvial lowlands within the glaciated area (fig. 2). General principles, drawn largely from previous investigations, are summarized for each geologic environment, and examples are provided wherever data are available.

Information on subsurface geology, permafrost, and ground water in Alaska is sparse, and in many areas there are no data. Therefore, it is possible to make only general statements on ground-water occurrence in each of the geologic environments. Extrapolation of data to different localities within the same environment is commonly difficult because local permafrost configurations and geologic conditions differ. The following summary of general principles, factors that influence variations in the configuration of permafrost, and available data at many localities in Alaska, nevertheless, may be useful in the search for additional ground-water supplies at these places and in undeveloped areas of the State.

This investigation, a part of the research program of the Water Resources Division, was made between September 1960 and June 1964. It was divided into two phases: (1) Preparation of an annotated bibliography of foreign and domestic literature (Williams, 1965) and (2) preparation of a summary and interpretation of the data existing in the literature and in U.S. Geological Survey records. Fieldwork was limited to brief trips to confer with geologists engaged in field mapping, to observations of test drilling near Rampart and McKinley Park station, to visits to Cape Lisburne (Feulner and Williams, 1967), and other sites in western and northwestern Alaska. Drillers' logs were collected and a few well inventories were made in the Fairbanks area. Information was collected from private and governmental sources in Anchorage and Fairbanks.

\section{BASIC DATA}

Data on the distribution and thickness of frozen ground are available from drillers' logs of water wells, foundation borings, test pits, exploratory oil wells, seismic shotholes, and mine and prospect shafts. The scattered exposures in riverbanks, sea cliffs, and placer mines generally do not provide information on the thickness of frozen ground nor on its relation to ground water. In an undeveloped region such as Alaska, subsurface data are necessarily limited. Most data were from the Tanana River valley near Fairbanks, where frozen ground is widespread, or from the Anchorage area and Matanuska Valley where permafrost poses no problem in obtaining ground water. A few groups of borings, wells, and shafts are concentrated at smaller settlements and at mineral exploration sites.

Of an estimated 15,000 records of wells, boring's, and shafts within the permafrost region, fewer than 1,500 provide data on the total thickness of frozen ground. The pertinent data are shown in figures 3-8 and on a larger scale (figs. 12-25) where data were fairly abundant.

Subsurface records logged by drillers may show the depth to which water in the ground is frozen, but do not show the lower limit of below $0^{\circ} \mathrm{C}$ ground temperature which, by definition, constitutes the base of permafrost. The base of frozen ground as recorded may lie above the lower limit of permafrost, because of the subzero freezing point of mineralized water or because of difficulties in recognizing whether unsaturated unconsolidated deposits or bedrock are frozen or unfrozen. The actual base of permafrost, defined by the $0^{\circ} \mathrm{C}$ isogeotherm, is determined only by temperature measurements. Although these measurements are available for some wells in northern Alaska, they are not available for most areas in Alaska. Therefore, the term "permafrost" in the sections of this report describing ground-water occurrence and local configuration of permafrost generally refers to the reported base of frozen ground.

All subsurface data available to April 1964 are used in this report. The writer is unfamiliar with the conditions under which most of the holes were constructed and lacks the necessary thermal data and supervised test drilling by which the data can be checked. Undoubtedly, many records are inaccurate because of difficulties such as those inherent in recognizing the frozen condition of unsaturated ground, lack of familiarity with the drilling characteristics of frozen ground, and use of excess drilling water, which tends to thaw the frozen ground adjacent to the hole.

Long-term water-level measurements have been made in only one well in permafrost near Fairbanks (Cederstrom, 1963; Waller, 1963, p. 11-12) and in a few wells in the Anchorage area and Matanuska Valley. Most of the water-level observations cited in 


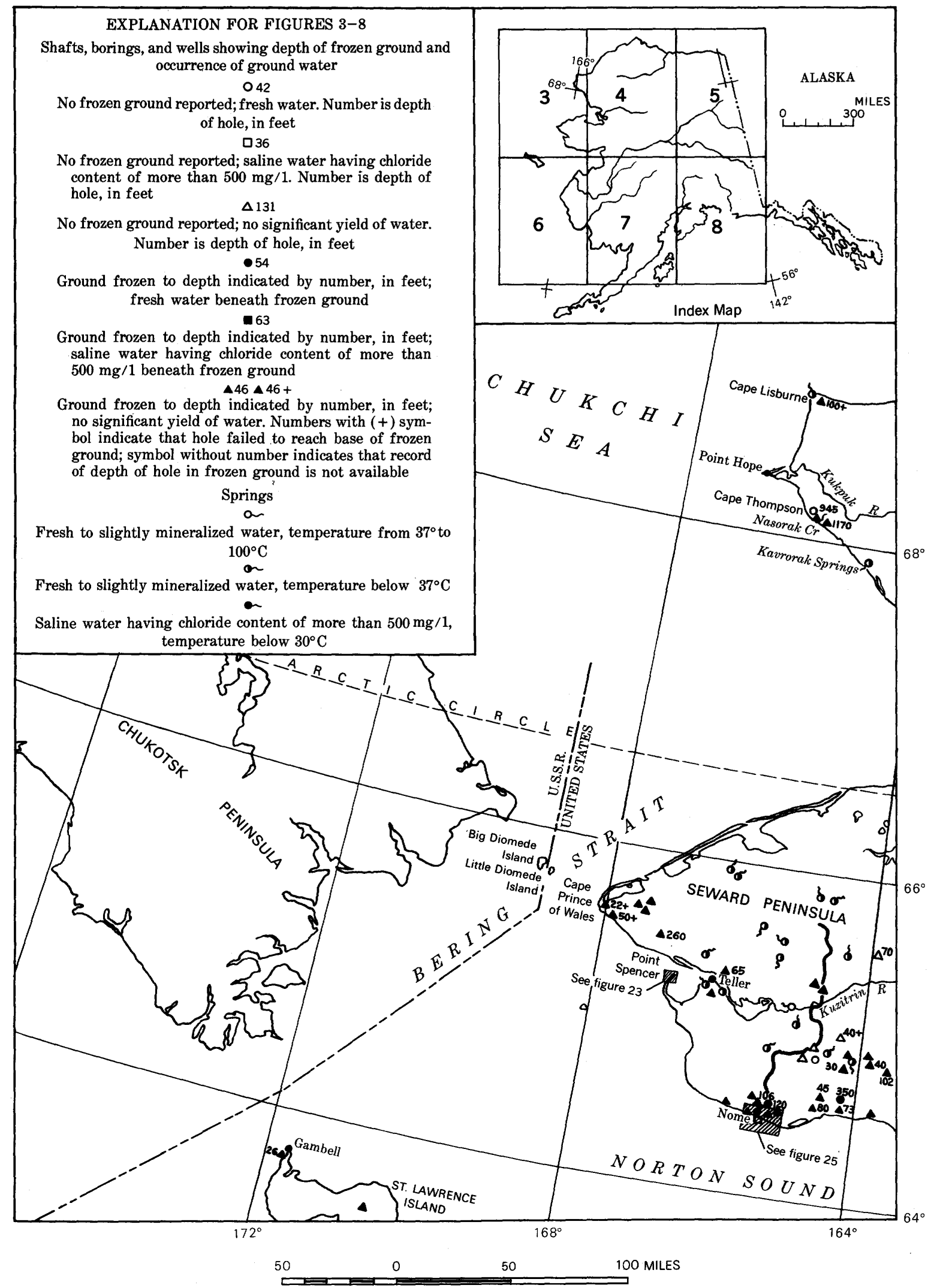

FIGURE 3.-Distribution of basic data used in this report. 
INTRODUCTION

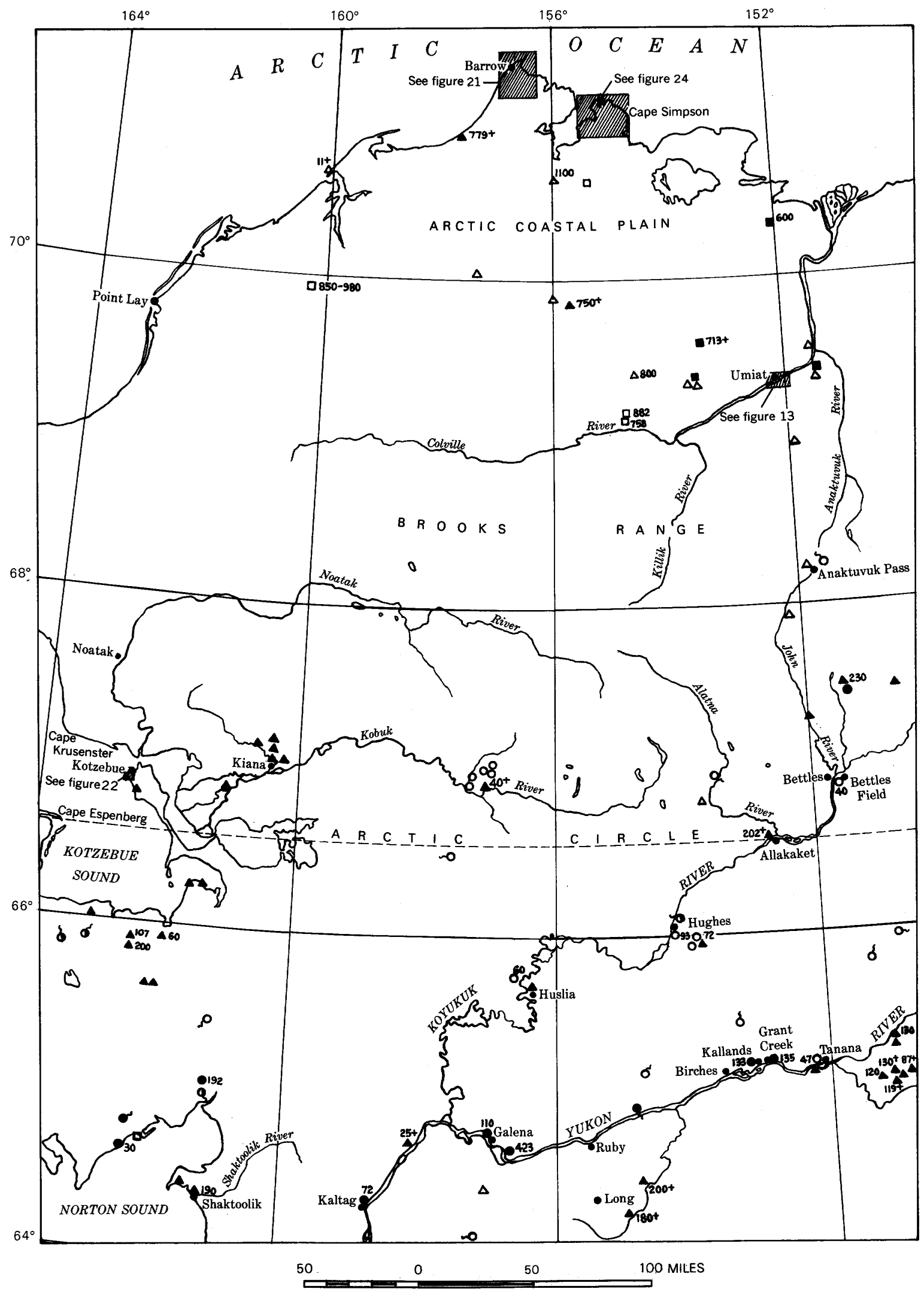

FIGURE 4.-Map showing distribution of basic data used in this report. 


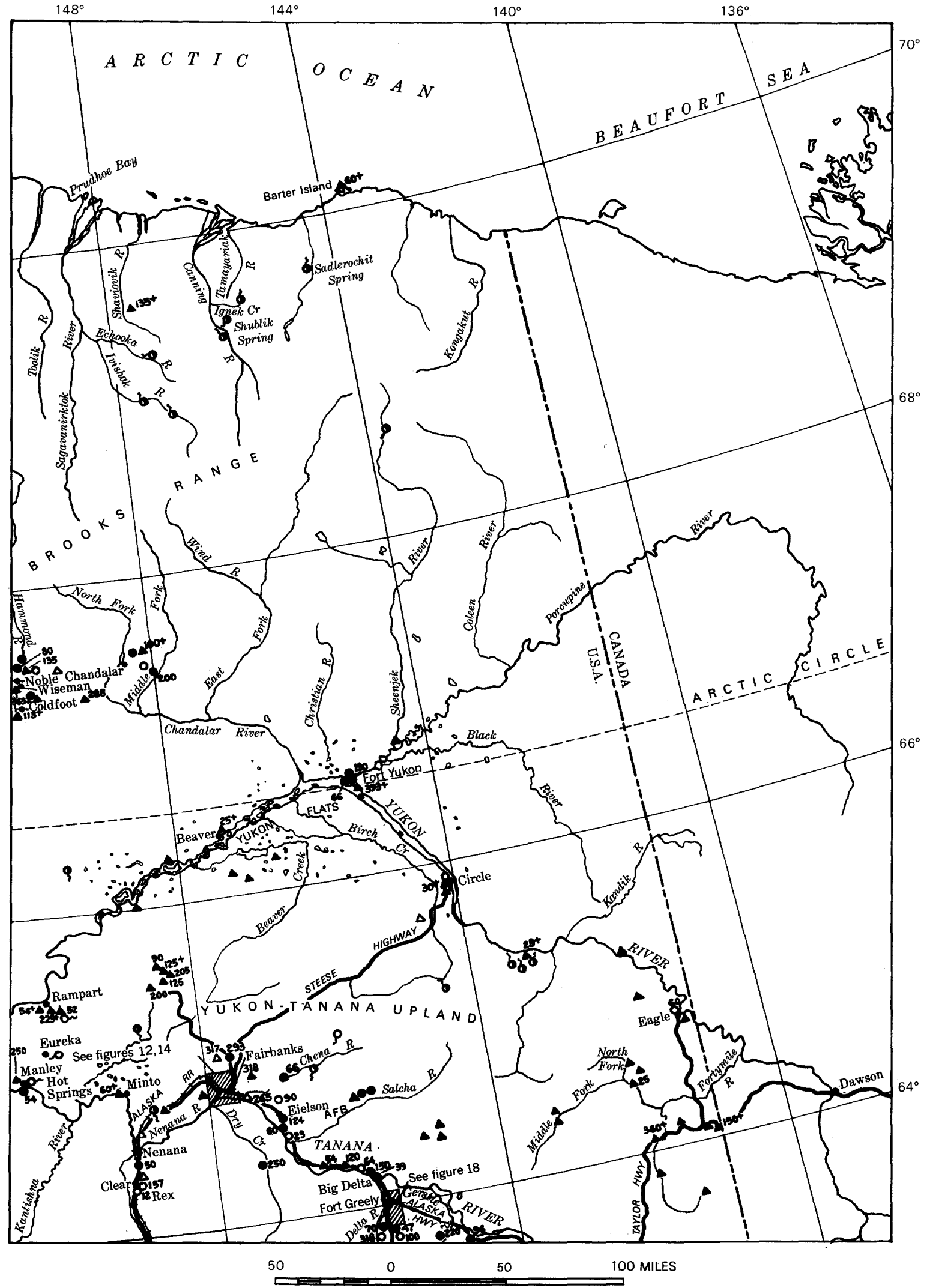

Figure 5.-Map showing distribution of basic data used in this report. 


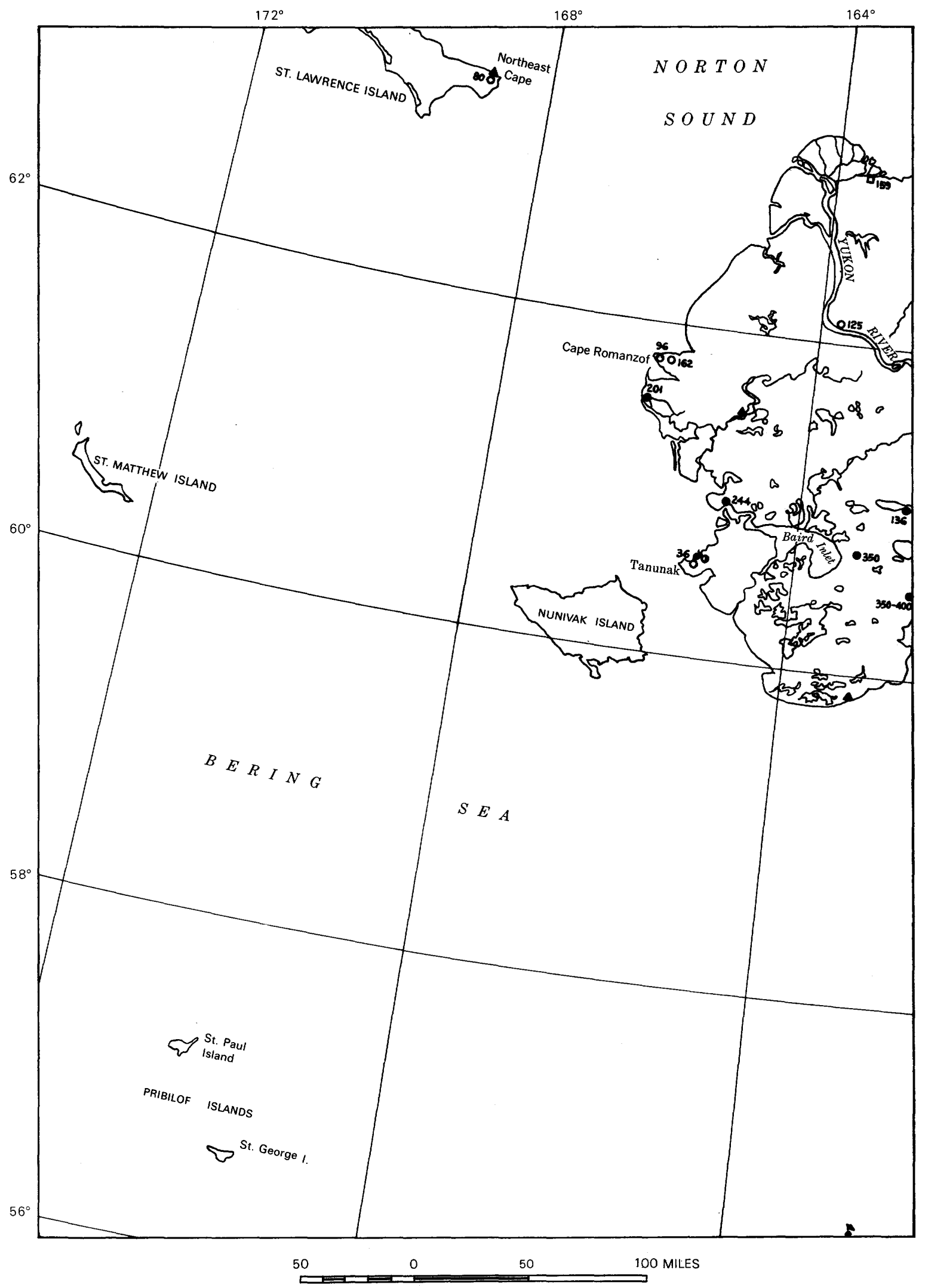

Figure 6.-Map showing distribution of basic data used in this report. 


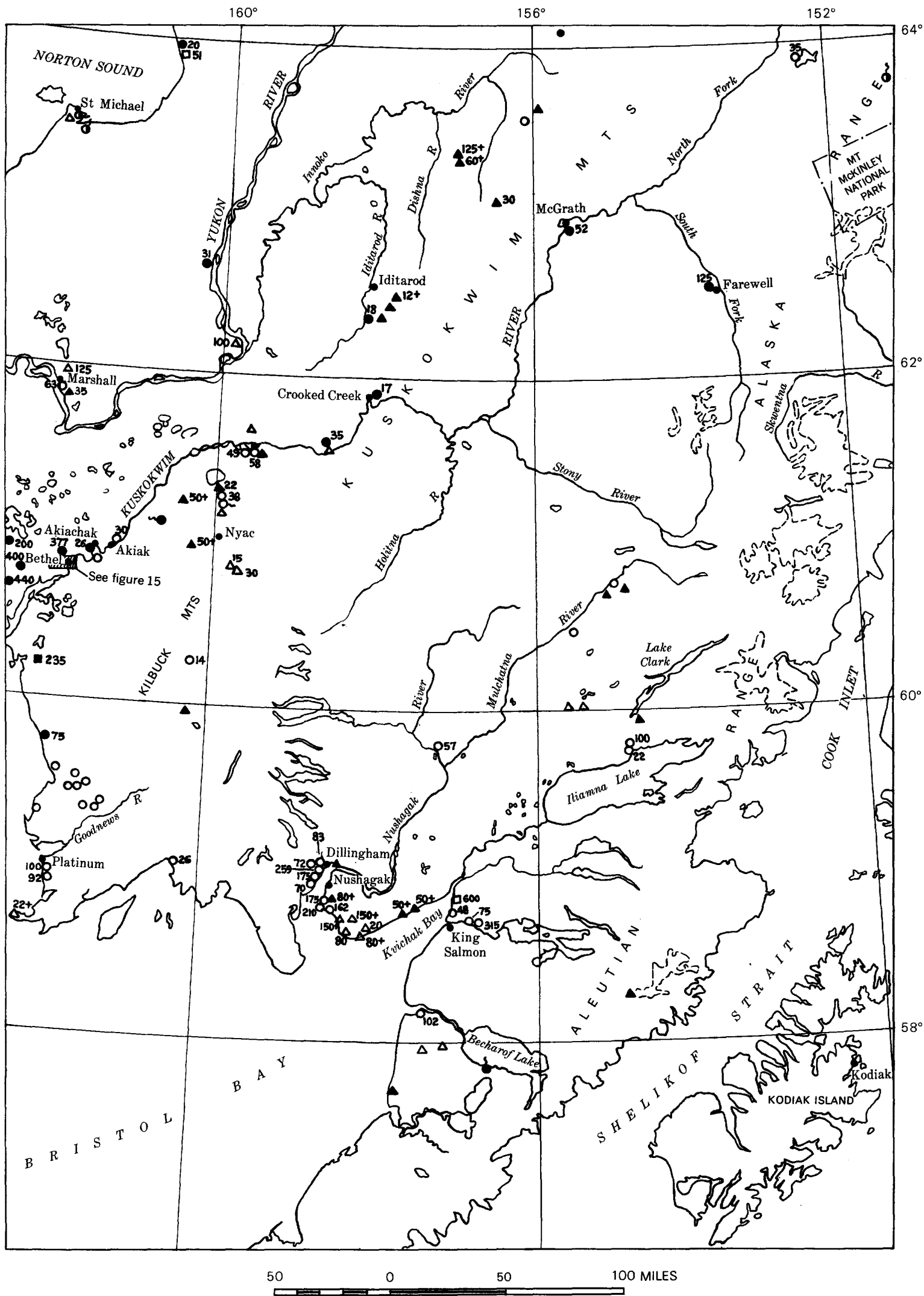

FiguRE 7.-Map showing distribution of basic data used in this report. 
INTRODUCTION

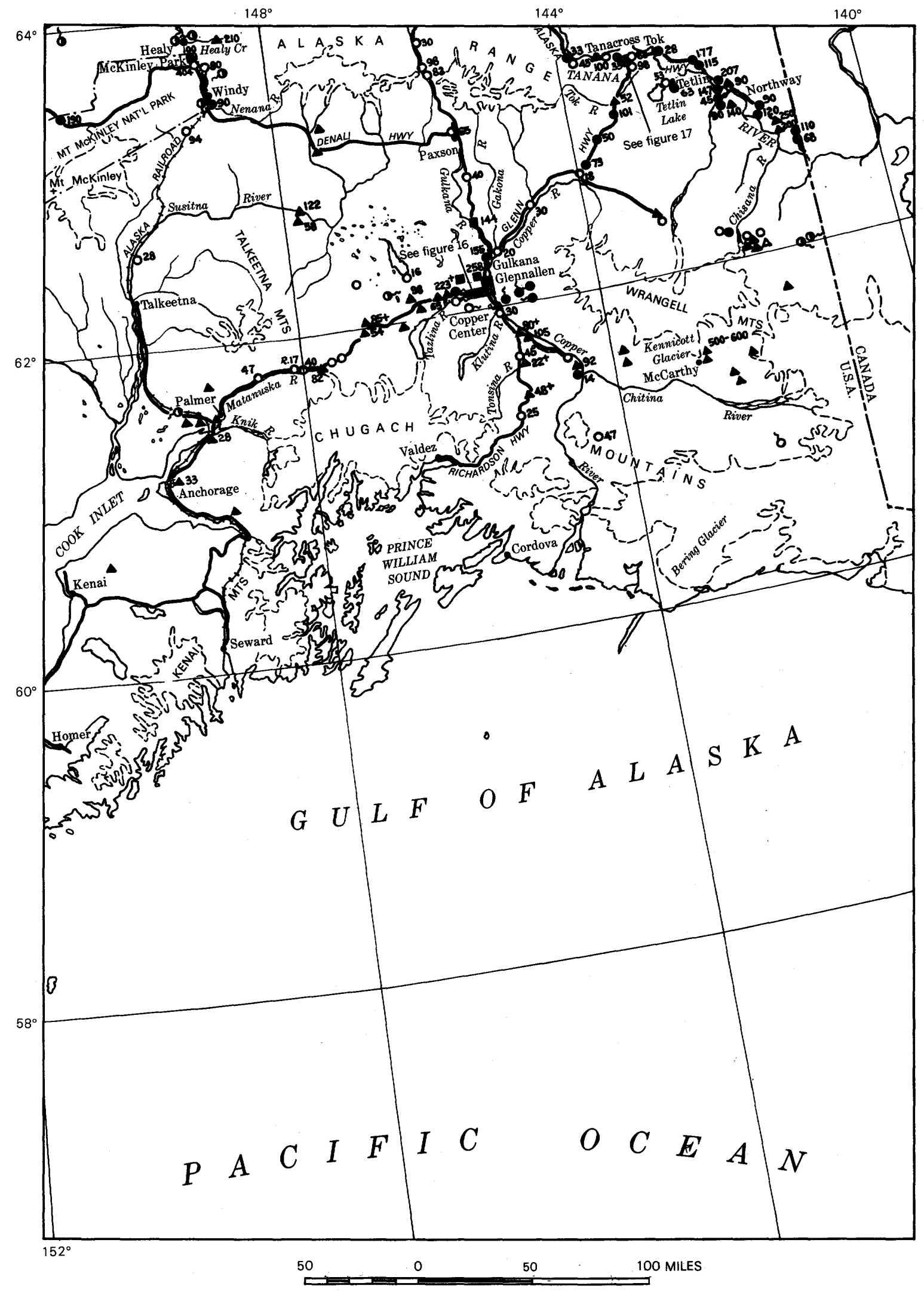

FiguRE 8.-Map showing distribution of basic data used in this report. 
this report were made by the driller during completion tests and were made in various years and different seasons. Simultaneous water-level observations have been made at Tok and Fort Greely to determine the slope of the water table or potentiometric surface.

Chemical analyses of ground water are available for most public supplies and military installations. A few analyses are tabulated by Lohr (1957, p. $6-7,10-11)$ and Moore $(1949,1950)$, and others are listed and interpreted in reports on Alaskan ground water among the references cited in this report. Water temperature has been measured in about 150 wells, of which 50 were drilled through permafrost.

\section{ACKNOWLEDGMENTS}

The following organizations supplied boring and well records: U.S. Army Engineer District, Alaska; Alaskan Air Command, U.S. Air Force; Department of Education and Department of Highways, State of Alaska; Bureau of Indian Affairs, U.S. Department of the Interior; Federal Aviation Administration; Pan American Petroleum Corp.; and Pure Oil Co. The following drillers and drilling companies furnished records: Earl McClure, Al Shott, Hatch Drilling Co., Thibideau Drilling Co., Maurice Butler, and A. Anderson, all of Fairbanks; Ray Alderton, Tok; Bayless and Roberts, Copper Center; and A. L. Nicholson, Bethel. Troy L. Péwé, former department head, and other members of the Department of Geology, University of Alaska furnished well data and unpublished reports and have discussed problems with the writer. Marvin D. Mangus, Atlantic Richfield Co., provided information on springs in the Brooks Range. Subsurface data and geologic background for areas not visited were furnished by colleagues in the Geological Survey. Transportation to western and northwestern Alaska was provided by Alaskan Air Command, U.S. Air Force, as part of an agreement under which the Geological Survey supplies technical assistance on problems of water supply. Jay L. Morgan, hydrologic engineering aid, made inventories of wells in selected areas near Fairbanks.

\section{PERMAFROST}

\section{DEFINITION AND TERMINOLOGY}

Permafrost is defined as soil, unconsolidated deposits, and bedrock at variable depths beneath the surface of the earth in which temperatures below $0^{\circ} \mathrm{C}$ have existed from 2 to thousands of years (Sumgin and others, 1940; Muller, 1947, p. 3). The term is defined exclusively on the basis of temperature, and it does not require the water within permafrost to be in the frozen state. Permafrost is synonomous with "perennially frozen ground" except where liquid water occurs even though the water temperature is below $0^{\circ} \mathrm{C}$ due to depression of the freezing point by dissolved mineral matter. The base of permafrost (fig. 9) is determined by the lower limit of ground temperatures that are below $0^{\circ} \mathrm{C}$, and not necessarily by the lower limit of frozen ground. The upper surface of permafrost is called the permafrost table (fig. 9). The active layer is the zone above permafrost that thaws in summer and freezes again in winter (Muller, 1947, p. 6). The depth to which seasonal temperature fluctuations extend into permafrost or into unfrozen ground is called the level of zero annual amplitude (fig. 9), beneath which the ground temperature remains virtually stable the year round (Muller, 1947, p. 218). The depth of the level of zero annual amplitude varies from place to place but is generally between 50 and 80 feet.

Permafrost may become thicker and areally more extensive, or it may become thinner and less extensive, in response to changes in the heat balance at the earth's surface. Permafrost that is out of thermal equilibrium with the present mean annual ground-surface temperature and that must have formed when the ground-surface temperature was lower than it is now, is termed "relict permafrost." In some places, notably near the southern limit of permafrost, relict permafrost is separated from the base of the active layer by a thickness of ground that has a temperature above $0^{\circ} \mathrm{C}$. Elsewhere, relict permafrost either is continuous with overlying permafrost that reflects present ground-surface temperature or is separated from the overlying permafrost by a zone having temperatures above $0^{\circ} \mathrm{C}$. Bodies of permafrost separated by a zone of positive temperature are called layered permafrost (Terzaghi, 1952, p. 33-34, fig. 13). Thermal data for Alaska were not available to determine whether any of the records of alternating frozen and unfrozen ground indicate actual layered permafrost. Additional terms are defined in glossaries by Muller (1947, p. 213-224), Hennion (1955), and Williams (1965, p. 15-37).

\section{ORIGIN AND HISTORY}

Permafrost is formed when the balance between net heat lost to the atmosphere at the surface of the earth and heat received at the surface from sources within the earth produces negative $\left({ }^{\circ} \mathrm{C}\right)$ ground 


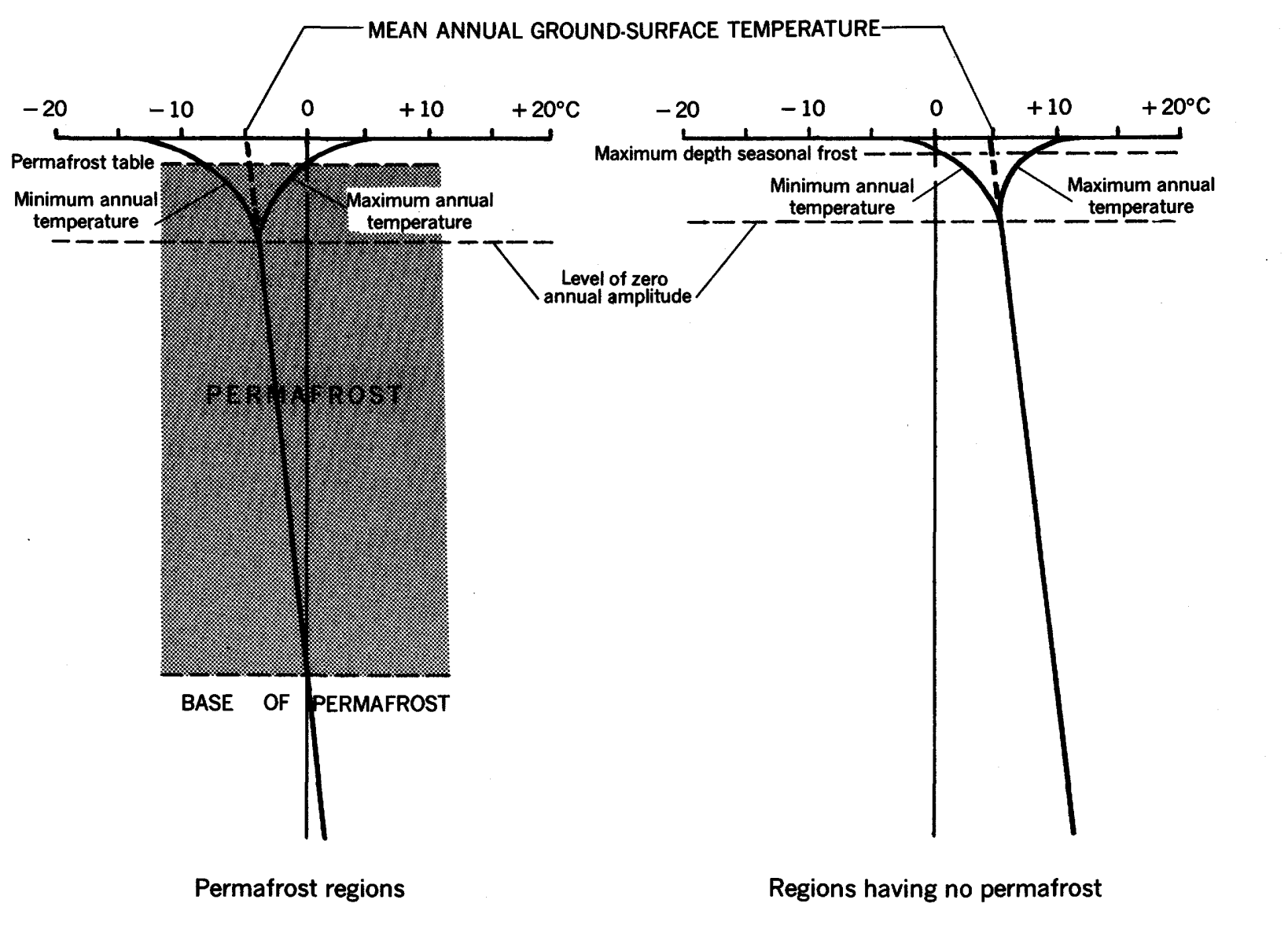

FIGURE 9.-Ground-temperature change with depth in permafrost regions and in regions having no permafrost.

temperature below the base of the active layer (fig. 9). But, at a given locality, the heat received from sources within the earth and the thermal properties of earth materials are relatively constant with time. Therefore, changes in the thermal regimen of permafrost at one place and differences in its regimen from one place to another nearby are largely a function of temporal changes or local differences in the factors that affect the temperature balance at the ground surface. These factors are: Solar radiation received at or transmitted from the surface; heat lost to the air or gained by convection or conduction; heat lost or gained by evaporation or condensation of surface moisture; heat conductivity, shading, and transpiration effects of vegetation; and reflectivity or albedo of the ground surface and its cover of vegetation (Carlson, 1952; R. J. E. Brown, 1965a, p. 20-25). The rate of change in the thermal regimen of permafrost at any locality depends on the magnitude of changes in one or more of these factors, their net effect on mean annual ground-surface temperature, and the thermal diffusivity of the rocks. Existing permafrost is, therefore, a product of fluctuations in the heat balance at the ground surface over a period of a few to thousands of years, and the local configuration of permafrost is a product of local differences in mean annual ground-surface temperature.

The thickness of permafrost is determined by the geothermal gradient and the mean annual groundsurface temperature (Terzaghi, 1952, p. 18). Where the depth of penetration of winter cold exceeds that of summer warmth, permafrost will gradually extend downward. If the factors controlling the heat balance at the ground surface remain unchanged, the $0^{\circ} \mathrm{C}$ isogeotherm, or base of permafrost, will eventually reach a depth at which equilibrium exists between the heat lost to the atmosphere and that gained from sources within the earth. Subsequent changes in the factors governing the heat 
balance at the surface will either raise or lower the ground-surface temperature, and permafrost will either degrade or aggrade farther. If the temperature of the ground below the maximum depth of seasonal thaw is raised and maintained above $0^{\circ} \mathrm{C}$, permafrost will degrade from above and below and will ultimately disappear. If formation of new permafrost takes place before the older permafrost has completely degraded, then layered permafrost may form in which the new and old permafrost are separated by a zone of positive temperature $\left(0^{\circ} \mathrm{C}\right)$. In other places, younger permafrost may extend downward to the upper surface of the older, or relict, permafrost.

The position of the permafrost table is primarily a function of the annual amplitude of temperature fluctuations about the mean (Lachenbruch and others, 1962, p. 798). Therefore, changes in the factors affecting heat gained or lost at the ground surface may affect the position of the permafrost table even though the mean annual ground-surface temperature is not changed. Those changes which do affect the mean annual ground-surface temperature and the thermal regimen of permafrost also will affect the position of the permafrost table.

Permafrost in Alaska was probably first formed during the glacial climate of early Pleistocene time. In unglaciated areas, permafrost has had a history of alternating aggradation and degradation in response to the climatic changes that corresponded to periods of glaciation and deglaciation. In areas covered by glaciers or by large proglacial lakes, insulation by thick ice or by water probably prevented formation of permafrost (Nichols, 1965, p. 174). The changing climates of Pleistocene and Holocene time have caused shifts in the position of isotherms of mean annual ground-surface temperature and in the southern limit of permafrost northward during interglaciations and interstages and southward during glaciations and stages.

Geologic studies of truncated ice wedges in permafrost show the depth of partial thaw of permafrost at Nome (Hopkins and others, 1960, p. 55) and at Fairbanks (Péwé, 1952, 1953, 1958a, b) during a warm climatic episode that followed the Wisconsin Glaciation. In the Copper River Lowland, most of the permafrost in the glaciolacustrine and glacial deposits of Wisconsin age was probably formed in Holocene time following withdrawal of a proglacial lake (Nichols, 1965, p. 172-175).

Geothermal studies along the Arctic coast have provided many data on present-day ground-surface temperatures, on temporal changes in the thermal regimen of permafrost, and on lateral heat flow caused by shifts in the position of surface-water bodies (Lachenbruch, 1960; Lachenbruch and others, 1960, 1961). For example, the mean annual ground-surface temperature at Barrow has increased $4^{\circ} \mathrm{C}$ since 1850 and $2^{\circ} \mathrm{C}$ since 1930 (Lachenbruch and Brewer, 1962). This warming at the surface has affected the temperature of permafrost to a depth of 300 feet. Analysis of geothermal data from Ogotoruk Creek valley near Cape Thompson suggests a post-Pleistocene marine transgression, a recent lagoon filling, and a $1^{\circ} \mathrm{C}$ increase in the mean ground-surface temperature during the last 50 years (Lachenbruch and others, 1960). These changes in ground-surface temperature may not necessarily be caused by warming of the air temperature, but may be caused by changes in the amount of distribution of precipitation, by changes in the vegetative cover, or by other factors.

\section{DISTRIBUTION AND MAXIMUM THICKNESS}

Most of the 12,500,000 square miles of the earth's land area that lies within the permafrost region is in the Northern Hemisphere (fig. 1). About half of the Soviet Union and Canada, 85 percent of Alaska, and parts of Scandinavia, Iceland, Mongolia, and China are included. Permafrost occurs in areas that are free of thick glaciers or ice caps in the northern 90 percent of Greenland, in Spitsbergen, in the Canadian and Soviet Arctic archipelagoes, and in Antarctica. It has been reported in subglacial till in a boring that penetrated more than 5,000 feet of the Greenland ice cap (C. C. Langway, oral commun., 1967). Permafrost is also found in the high mountains of the temperate regions (Fisher, 1953; Streiff-Becker, 1953; Black, 1954; Mathews, 1955; Lliboutry, 1957; Baranov, 1958; see especially summary by Baranov, 1959, p. 9-28).

The greatest known thickness of permafrost, 2,850 feet, has been reported in the mountains of the East Siberian District, U.S.S.R. (Tolstikhin and others, 1963, p. 164). Elsewhere in the Northern Hemisphere, the maximum known thickness is beneath land bordering the Arctic Ocean. Permafrost is about 2,000 feet thick at Kozhevnikov Beach near Nordvik, U.S.S.R. (fig. 1) (Shvetsov, 1951; Pinkow, 1943); 1,330 feet near Point Barrow, Alaska (Brewer, 1958b, p. 19) ; 1,050 feet in Spitsbergen (Werenskiold, 1922); and 1,000 feet at Thule, Greenland (Sturgis, 1953). In the Canadian Arctic archipelago, it is 1,280 feet thick at Resolute (Misener, 1955) and about 1,500 feet at Winter Harbour, Melville Island (U.S. Geological Survey, 
1963c). The maximum recorded thickness in Antarctica is 500 feet beneath a glacier-free area (Shumskii, 1959).

\section{REGIONAL ZONATION}

The southern limit of permafrost in Alaska was mapped by Nikiforoff (1928), Bratsev (1940), and Taber (1943). Smith (1939, pl. 14) showed localities in which permafrost was known. The first maps of regional zonation (Black, 1950, fig. 1; 1954, fig. 1), based on the Russian classification, subdivided the permafrost region of Alaska into three zones. They were (Black, 1954, p. 842-843) : (1) Continuous-permafrost zone in which ground temperature at a depth of 30-50 feet is generally lower than $-5^{\circ} \mathrm{C},(2)$ discontinuous-permafrost zone in which temperature ranges from $-5^{\circ} \mathrm{C}$ to $-1^{\circ} \mathrm{C}$, and (3) sporadic-permafrost zone in which ground temperature is higher than $-1^{\circ} \mathrm{C}$. According to Black (1954, p. 842), the thickness of permafrost in Alaska is: 800-1,200 feet nearly everywhere in the continuous zone, except beneath a few large lakes and rivers; as much as 200-400 feet in the discontinuous zone; and generally less than 100 feet in the sporadic zone. Black's classification was modified by Hopkins, Karlstrom, and others (1955, fig 5) by adding a nopermafrost zone in which only isolated areas of permafrost exist and by eliminating ground temperatures in defining the zones. Some of the more recent maps modify the boundaries of the earlier reports, for example, Holmes, Hopkins, and Foster (1965, p. 88), Péwé (1965, p. 78), Williams and Waller $(1965$, p. 160$)$, and the present report follow the usage of Black (1954) and Hopkins, Karlstrom and others (1955) in drawing the boundaries between the discontinuous and continuous zones (fig. 9). The present report eliminates the sporadic zone in order to conform the usage in Canada and because available records of ground temperature at or near the level of zero annual amplitude in Alaska (fig. 9) are inconsistent with its original definition and delineation on maps. Ferrians (1965) has prepared a permafrost map of Alaska using a new classification based on the relative proportion of unfrozen and frozen ground, thickness of permafrost, and terrain considerations.

The continuous-permafrost zone occupies the area draining to the Arctic Ocean and to the Chukchi Sea. According to records available for the Arctic drainage basin, the depth to the base of permafrost ranges from about 500 to 1,300 feet, and permafrost temperature at or below the level of zero annual amplitude ranges from $-5.5^{\circ}$ to $-10.6^{\circ} \mathrm{C}$.
The permafrost table is within a few feet of the surface except beneath lakes and streams, where the permafrost table is depressed from a few feet to several hundred feet due to the warming effect of the water. The record of deepest permafrost in that part of the continuous zone south of the Brooks Range is greater than 365 feet, but deeper drill-hole temperature measurements are not available from that area.

The discontinuous-permafrost zone occupies most of the area between the southern foothills of the Brooks Range and the Pacific coastal ranges, most of which drains to the Bering Sea and Pacific Ocean. The extent to which permafrost is perforated by unfrozen zones (having temperatures above $0^{\circ} \mathrm{C}$ ) depends largely on local conditions, but the proportion of unfrozen ground is generally greater in the south than in the north. Known depth to the base of frozen ground ranges from a few feet to about 600 feet. Although permafrost temperature at the level of zero annual amplitude is expected to range from $0^{\circ}$ to $-5^{\circ} \mathrm{C}$ when an adequate observational network becomes established, the measurements now available are between $-0.3^{\circ}$ and $-2.2^{\circ} \mathrm{C}$.

The southern limit of permafrost shown in figure 10 lies farther south than that of previous reports (Black, 1954, fig. 1; Hopkins and others, 1955, fig. 5; and Ferrians, 1965), but is approximately the same as that of Péwé (1965). As drawn, the line represents the southernmost known permafrost in lowland areas, and the writer's estimate of its approximate position in mountainous regions where data are lacking. The fact that permafrost is known in the Coast Range of British Columbia (Mathews, 1955) and in many mountains in temperate regions (Baranov, 1959) suggests that permafrost may also be present locally at high elevations in the Aleutian Range, Kodiak Island, and the Coast Range of southern and southeastern Alaska, far south of the limit shown in figures 1 and 10.

\section{LOCAL CONFIGURATION}

Although regional zonation is useful in classifying and mapping permafrost "on a nationwide or statewide scale, local configuration is far more important in studies of ground-water occurrence. Information on local variations in thickness, areal extent, and thermal regimen is required to understand the effects of permafrost on ground-water hydrology. The variations depend on local differences in the mean annual ground-surface temperature. The data and the methods necessary for quantitative analysis of the factors that affect the mean 
annual ground-surface temperature are not available. Nevertheless, the effect of these variations on the temperature and on the local configuration of permafrost is discussed below, qualitatively, in terms of climatic, vegetative, topographic, hydrologic, and geologic differences between local areas.
EFFECT OF LOCAL CLIMATIC DIFFERENCES

Local differences in distribution of net radiation, rainfall, snowfall, and effect of wind in transmitting or removing heat from the ground surface and in redistributing the snow cover determine some of the variations in distribution, thickness, and tem-

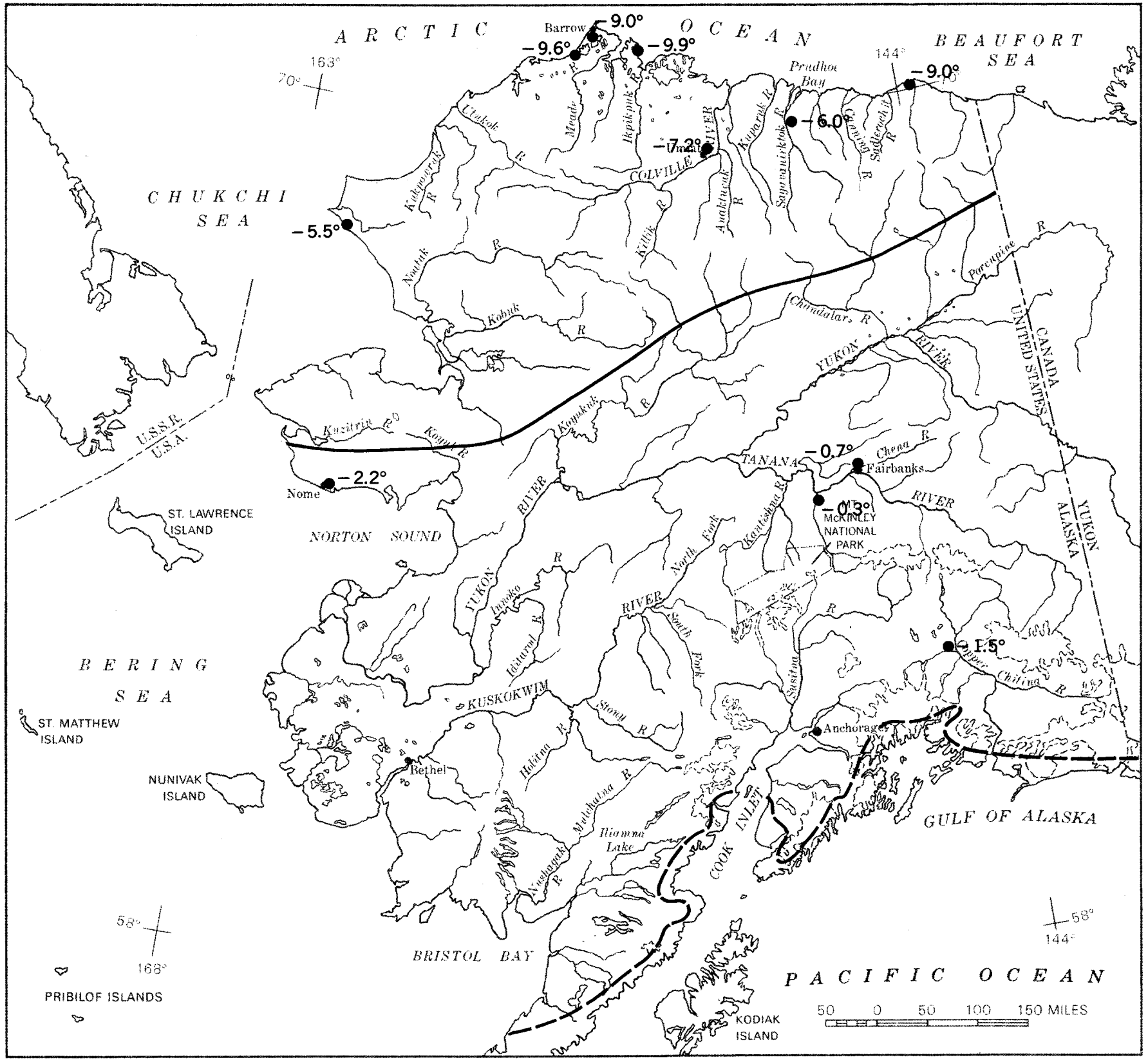

$$
\bullet-5.5^{\circ}
$$

Data point showing temperature of permafrost at level of zero annual amplitude, in degrees celsius

EXPLANATION

Approximate southern limit of continuous permafrost
Approximate southern limit of discontinuous permafrost

FiguRE 10.-Permafrost zones and selected permafrost temperature: 
perature of permafrost. Changes in regional climate with time or in one of the climate components, such as net radiation or snowfall, will affect the mean annual ground-surface temperature. Such changes in ground-surface temperature in local areas may be in the same direction but of different magnitude because they are influenced by the local effects of vegetation, thermal properties of soils, topography, geology, and hydrology. Annual fluctuations in the climatic components affect the thickness of the active layer.

On a regional basis, analysis of mean annual air temperatures measured 4 feet above the ground at meteorological stations and analysis of freezing and thawing indexes derived from these air-temperature measurements have been used to find a correlation between the southern boundary of permafrost and the boundary between continuous and discontinuous permafrost (R. J. E. Brown, 1960, p. 176, 1965b). Although few correlations were found, the southward increase in mean annual air temperature and thawing index and decrease in freezing index are generally parallel to southward regional changes in thickness, extent, and temperature of permafrost. For example, the southern limit of permafrost in Alaska (fig. 10) lies along the $+2{ }^{\circ} \mathrm{C}$ isotherm of mean annual air temperature uncorrected for topography, and the boundary between the continuousand discontinuous-permafrost zones lies along the $-8^{\circ}$ and $-10^{\circ} \mathrm{C}$ isotherms as calclated by Péwé (1965).

Local differences in snow distribution and differences in the time of maximum accumulation of snow and snow drifting may cause local differences in ground-surface temperature as shown in the following example. Calculations of the shift in mean annual ground-surface temperature due to snow showed that the differences between mean annual ground-surface and air temperatures caused by snow cover are $4^{\circ}-5^{\circ} \mathrm{C}$ at Barrow on the Arctic coast and as much as $7^{\circ} \mathrm{C}$ at Umiat, 80 miles inland (Lachenbruch, 1959, p. 28). Because both localities have the same mean annual air temperature, the difference in ground temperature due to snow may explain the difference of about $2{ }^{\circ} \mathrm{C}$ in permafrost temperature between these localities (Lachenbruch, 1959 , p. 28-29). Absence of permafrost in water wells drilled in cirques and protected hollows where snow cover is tens of feet thick has been noted in western Alaska at Cape Romanzof and at Northeast Cape, St. Lawrence Island (fig. 6).
EFFECT OF LOCAL DIFFERENCES IN VEGETATION

Local differences in vegetation are important in controlling the temperature at the ground surface. These differences include: (1) Type of plant cover and its effects on heat transfer, shading, wind, and precipitation, (2) insolation reaching the ground surface, (3) reflectivity and absorbtivity of solar radiation, and (4) amount of convection and transpiration (Benninghoff, 1965, p. 9-13; R. J. E. Brown, 1965a, p. 20-25). The differences affect both the annual range in ground-surface temperature, which regulate the thickness of the active layer, and the mean annual temperature of the ground surface, which influences the thermal regimen of permafrost.

In the continuous-permafrost zone the effects of vegetation are reflected largely by differences in thickness of the active layer and do not appear to change significantly the thermal regimen of permafrost (R. J. E. Brown, 1965a). But, in the discontinuous-permafrost zone, where ground-surface temperature is near $0^{\circ} \mathrm{C}$, vegetation may influence the thickness of the active layer and may determine whether permafrost is present or absent (Benninghoff, 1965). Removal of vegetation by man, or its alteration by natural change such as forest fires, can raise the ground-surface temperature sufficiently to thaw permafrost to depths of 35-40 feet in some parts of the discontinuous zone, and can alter the thermal regimen of permafrost below that depth. On the other hand, the natural plant succession, by changing the character of the vegetation, may favor aggradation of permafrost (Tulina, 1936). Lack of vegetation at high altitudes is cited as one of the causes of thick permafrost on summits and upper slopes of mountains in the discontinuous-permafrost zone of Canada (Wernecke, 1932; Ives, 1960; Annersten, 1963).

\section{EFFECT OF LOCAL TOPOGRAPHIC DIFFERENCES}

Local effects related to topography are caused by increasingly cold microclimate with higher altitude and by topographic irregularities that cause differences in shading and exposure to insolation, uneven distribution of snow cover, and exposure to wind. Increasingly cold microclimate with altitude is demonstrated by the presence of permafrost at high altitudes in temperate regions. Mean annual groundsurface temperature is lower and permafrost is thicker and more extensive on shaded, northwardfacing slopes than on southward-facing slopes. Local differences in relief cause uneven distribution of snow which is blown into depressions and removed from ridges. 
EFFECT OF LOCAL HYDROLOGIC DIFFERENCES

The warming effect of the ocean, a lake, or a river on ground-surface temperature is responsible for large local differences in permafrost temperature, thickness, and areal extent. The hydrologic thermal effects are determined by: (1) The magnitude of the difference between the temperature of the ground surface adjacent to a body of water and the temperature of sediments immediately beneath the water, (2) the thermal properties of the earth materials, and (3) the geologic history of the body of water. These effects may extend to a depth of several hundred feet (Lachenbruch, 1957a). Differences between ground-surface temperature adjacent to and beneath glaciers and thick accumulations of snow cause similar local variations in permafrost characteristics.

\section{EFFECT OF THE OCEAN}

The effect of the ocean on the configuration of permafrost has been calculated from geothermal data from Barrow, Cape Simpson, and Cape Thompson, Alaska. Near Barrow, ground temperature at a depth of 90 feet increases from $-7.33^{\circ} \mathrm{C}$ beneath the land 350 feet from shore to $-0.96^{\circ} \mathrm{C}$ in ocean-bottom sediments (Brewer, 1958b, table 1). The indicated depth of permafrost decreases from 1,330 feet 8 miles from the coast to 1,045 feet at a point 1,200 feet from the coast and to 670 feet at a point of land only 400 feet from the beach (MacCarthy, 1952). The latter two figures are uncorrected for the thermal effects of nearby lakes and possible shifts in the shoreline (Brewer, 1958b, p. 24). Ocean temperatures near Barrow are below $0^{\circ} \mathrm{C}$, and permafrost may be expected in ocean-bottom sediments beneath ocean depths of less than 500-1,000 feet, where the temperatures are above $0^{\circ} \mathrm{C}$ (Brewer, $1958 \mathrm{~b}$, p. 25). However, water in the sediments may be unfrozen if it is saline. From theoretical considerations, Lachenbruch (1957a) does not expect permafrost to occur at depths greater than $\mathbf{1 0 0}$ feet below the ocean bottom farther than a few thousand feet from shore, except where shorelines are transgressing. No studies have been made of the thermal effect of the ocean on distribution of permafrost in the discontinuous zone.

\section{EFFECT OF LAKES}

Studies of the effect of lakes on the thermal regimen of permafrost have been made in the continuous-permafrost zone of northern Alaska (Lachenbruch, 1957b; Brewer, 1958a, b; Lachenbruch and others, 1962) and of Canada (Johnston and Brown, 1961, 1963; W. G. Brown, 1963). The lakes of northern Alaska may be divided into: (1) Those less than 7 feet deep, which normally freeze to the bottom in winter and (2) those more than 7 feet deep which do not freeze to the bottom in winter (Lachenbruch and others, 1962, p. 797). The permafrost table beneath the shallow lakes that are 2-3 feet deep is generally within 2 feet of the lake bottom, but permafrost temperatures beneath the lake are as much as $3^{\circ} \mathrm{C}$ warmer than those beneath the surrounding tundra (Brewer, 1958b, p. 25). Beneath small lakes that do not freeze to the bottom in winter (fig. 11), the permafrost table is depressed into the shape of a saucer, and an upward indentation is formed in the base of permafrost. The thermal effect of large, deep lakes (fig 11) may form an unfrozen zone that perforates the permafrost (Lachenbruch and others, 1962, p. 798).

For example, thermal studies beneath Imikpuk Lake, one of the small, deep lakes near Barrow (Brewer, 1958a, p. 284) show that the $0^{\circ} \mathrm{C}$ isogeotherm lies at a depth of 190 feet, but that the unfrozen zone may be even deeper because of depression of the freezing point of saline ground water in bedrock beneath the lake.

The history of formation of lakes is especially important because many are formed by the cave-in or thaw process. The depression occupied by cave-in type lakes was formed initially by collapse of the ground following thaw of ground ice. Many such lake basins have subsequently been filled by peat and organic-rich sediment which become frozen. The basins may be reopened by thawing to form a second-generation lake (Wallace, 1948; Hopkins, 1949). Lakes that occupy abandoned channels of rivers exert a warming effect on ground temperatures, which is complicated by the earlier thermal effect of the river and by the time elapsed since the river abandoned its channel. Proglacial lakes of Pleistocene age may have prevented formation of permafrost and perhaps degraded preexisting permafrost (Nichols, 1965, p. 172-175).

Although geothermal studies have yet to be applied to lakes in the discontinuous-permafrost zone of Alaska, the same principles are applicable as in the continuous zone. In the discontinuous zone, where permafrost temperature is higher and the permafrost is thinner than in the continuous zone, a greater number of the small, deep lakes may be underlain by unfrozen zones that perforate the permafrost, and correspondingly, the unfrozen zone beneath large, deep lakes would be larger. 
EFFECT OF RIVERS

In the continuous-permafrost zone, only the largest rivers produce a temperature anomaly that is great enough to form an unfrozen zone through the permafrost. In northern Alaska, the Colville River has formed an unfrozen zone several hundred feet deep beneath its bed. The unfrozen zone may perforate permafrost, as suggested by Black (p. 119, in Hopkins and others, 1955). Drilling beneath smaller streams, such as the shallow, braided Shaviovik River (Brewer, 1958b, p. 26, fig. 10) and Selin Creek near Cape Lisburne (Feulner and Williams, 1967) showed that permafrost exists at shallow depths beneath the streambeds. The permafrost temperature beneath the Shaviovik River is $3^{\circ} \mathrm{C}$ warmer than that beneath the tundra bordering the stream to a depth of 135 feet (Brewer, 1958b, fig. $10)$, but Brewer $(1958 \mathrm{~b}$, p. 26$)$ expects that the temperature curves of permafrost beneath the tundra and beneath the stream will converge below that depth. Shallow, sluggish streams connecting lakes on the Arctic coastal plain are underlain by shallow, linear unfrozen zones and linear indentations in the base of permafrost (fig. 10) (Lachenbruch and others, 1962, p. 798).

In the discontinuous-permafrost zone, unfrozen zones that perforate permafrost lie beneath most large and medium-sized rivers. The minimum size of rivers having such unfrozen zones varies with the heat budget of the river and the mean annual ground-surface temperature in the surrounding terrain. The minimum size required for formation of an unfrozen zone that perforates permafrost becomes smaller southward, which is consistent with the regional zonation in which permafrost has higher temperature and smaller areal extent and thickness toward the south. Evidence for the existence of unfrozen zones that perforate the permafrost beneath rivers in Alaska is limited to data from borings beneath the Tanana River at Nenana (fig. 5) and along riverbanks or on islands in the Kuskokwim, Yukon, Tanana, and smaller rivers. These rivers are discussed in the sections describing ground-water occurrence. Data needed for calculating the thermal effect of rivers on permafrost according to the methods of Lachenbruch and W. G. Brown are not yet available for the discontinuouspermafrost zone of Alaska.

Migration of a river across its valley or other shifts in the position of the channel cause migration of the unfrozen zone beneath the river. Not only does the thermal effect of the river influence the extent of the unfrozen zone, but the speed of migration influences the length of time available for the thermal effects to alter the thermal regimen of the permafrost. As a river migrates, it erodes the

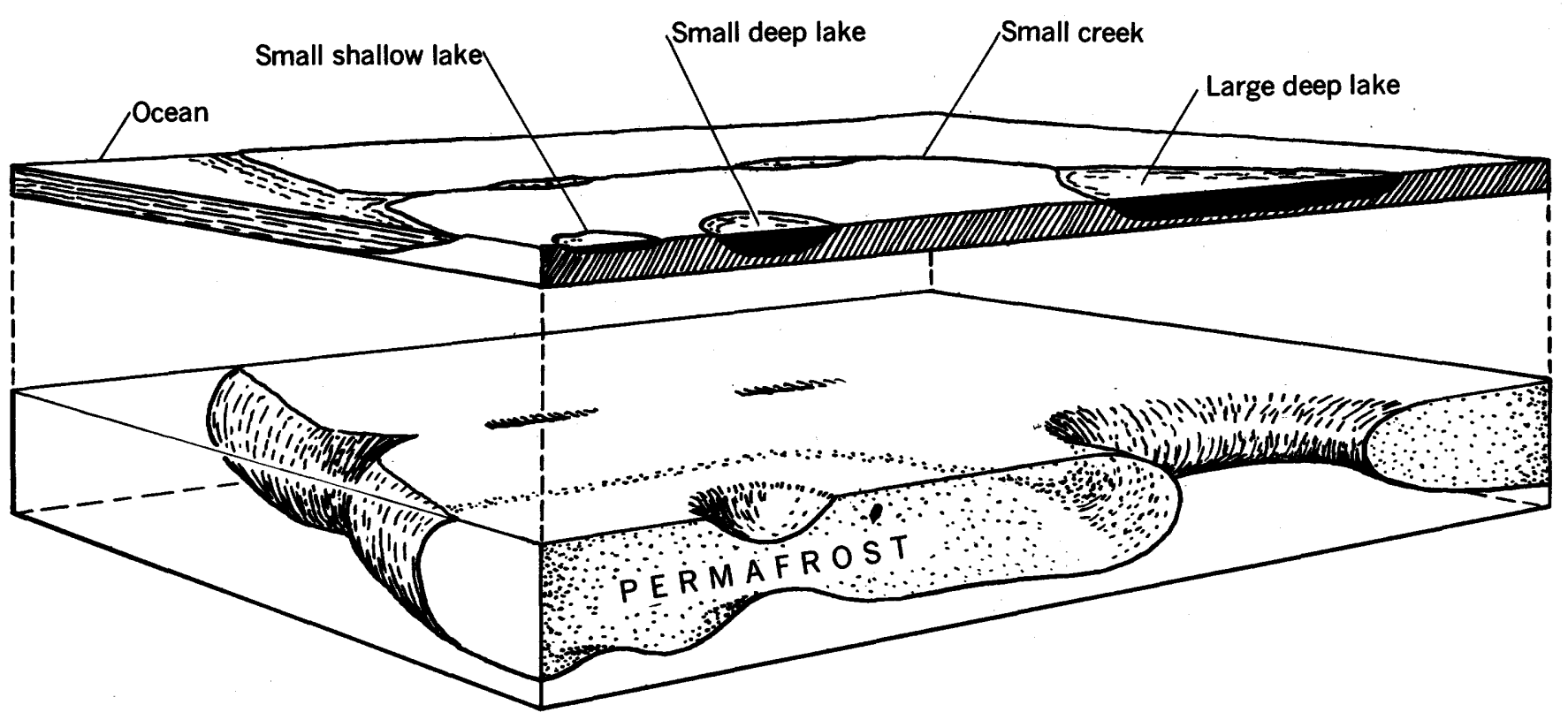

Figure 11.-Schematic representation of the effect of bodies of water on configuration of permafrost in the continuouspermafrost zone. (Modified from Lachenbruch and others, 1962.) 
deposits along its cutbank and deposits material along the slip-off slope. The deposits on the cutbank side of a migrating river have been subjected to warming action of the river for a short period and have been exposed to cold air for a longer time than the deposits along the stream and on the slip-off slope. Studies in the Soviet Union show that permafrost on the cutbank side is commonly colder than on the slip-off side (Mordvinov, 1940). The newly formed deposits of the slip-off slope are initially unfrozen, but become frozen with passage of time, as the river migrates (Péwé, 1947, 1948a). The local configuration of permafrost and its temperature, therefore, are closely related to the history of river migration.

\section{EFFECT OF GROUND WATER}

Ground water in contact with permafrost may: (1) Lower or raise the temperature of permafrost by conduction, (2) be cooled or frozen, or (3) establish an equilibrium in which no differential heat exchange takes place. Aggradation or degradation of permafrost may change the circulation pattern, temperature, and velocity of ground water. No quantitative data are available on the effect of ground water on the thermal regimen and local configuration of permafrost.

The role of ground water in affecting local configuration of permafrost was stated by Hopkins, Karlstrom, and others (1955, p. 117) as follows:

Heat is distributed through earth materials more rapidly by circulating water than by direct conduction. Thus, active circulation of water, both at the surface and at depth, promotes thawing of permafrost and retards formation of new permafrost. Owing to more active water movements, streams generally are underlain by deeper and wider unfrozen areas than are lakes, and coarse, permeable sand or gravel is more likely to be free of permafrost than is impermeable silt. Theis $(1944$, p. 6) made the following statement on this subject:

The role of normal ground water in preventing the formation of permafrost would seem to be questionable, at least until more evidence is obtained. Ground water customarily moves at such a slow rate that it could not travel far between frozen beds without itself freezing. It is probable that some of the phenomena ascribed to movement of ground water can be explained as the effects of the lateral movement of heat by conduction from an abnormally warm area, such as a river bed. The ground water may act only as a supplementary agent in spreading the heat of the river bed laterally.

Both Theis (1944, p. 6) and Hopkins, Karlstrom, and others $(1955$, p. 117) stated that where the ground is unfrozen and permeable and where the water table lies at depth, percolating water from summer rains and snowmelt is effective in carry- ing heat downward faster than it could be carried by conduction. Hopkins, Karlstrom, and others (1955) speculated that percolation of water through talus, coarse alluvium, and shattered bedrock on southward-facing mountain slopes aids in thawing seasonal frost and in maintaining permafrost-free areas. They and most other authors agree that ascending waters of hot springs maintain unfrozen zones through the permafrost.

EFFECT OF GLACIERS

The distribution and temperature of permafrost beneath glaciers depend on the magnitude of temperature differences at the ground surface and that adjacent to the ice. This magnitude depends on the thickness of the ice and the thermal gradient within the ice. Mathematical treatment of the problems of heat flow beneath glaciers in Spitsbergen (Werenskiold, 1922, 1953) showed that beneath an active glacier, the ground-surface temperature is practically at the melting point of ice and that water flows from the glacier even in winter. If the glacier is more than 1,300 feet wide, permafrost, which is formed by lateral heat flow beneath ground adjacent to the glacier, cannot exist beneath the central part of the glacier.

Quantitative studies in Antarctica by Zubov (1959) have shown that if the ice thickness is less than a certain limiting value, the $0^{\circ} \mathrm{C}$ isotherm will extend into the ground, and permafrost will exist beneath the glacier. If ice thickness exceeds this value, the $0^{\circ} \mathrm{C}$ isotherm will lie within the glacier, and a mixture of water and ice will be found near the base of the glacier. Tien (1960) has shown that if the ice cap has constant physical properties, grows at a constant rate from an initial zero thickness, is internally static, and is subject to linear climatic change and a constant geothermal heat flux, then the temperature at the bottom of the glacier will increase with time and will eventually reach the melting point of ice. These studies show that permafrost may be absent under large glaciers, but that it may lie under small glaciers and beneath the margins of large glaciers. However, C. C. Langway (oral commun., 1967) reported that a test boring through about 5,300 feet of ice in the Greenland ice cap near Thule terminated in frozen glacial till. Permafrost was observed by Mathews (1955) beneath the margin of a small glacier in the Coast Range of British Columbia, Canada, and by Roethlisberger (1961) beneath the edge of the Greenland ice cap. 
No studies have been made of the thermal regimen of the ground beneath Alaskan glaciers. However, winter floods of subglacial water from Kennicott Glacier, near McCarthy (fig. 8) (Moffit and Capps, 1911), show that water is contained in reservoirs either within the ice or at the ice-ground interface, and that the ground is probably unfrozen beneath a part of the glacier. At the present state of knowledge, then, it appears that behavior of permafrost in relation to glaciers is variable and unpredictable.

\section{EFFECT OF LOCAL GEOLOGIC DIFFERENCES}

Differences in physical properties of unconsolidated deposits and of bedrock affect the rate at which changes in ground-surface temperature are transmitted downward. Geologic history of landforms determines the length of time during which the ground surface has been exposed to fluctuating climates favoring aggradation or degradation of permafrost and the depth to which the temperature fluctuations have penetrated. Geologic conditions influence local and regional differences in the quantity of heat reaching the surface from sources within the earth.

The rate of downward transmittal of heat resulting from changes in the mean annual ground-surface temperature is affected by local differences in the thermal diffusivity of the rocks. Equal changes in the ground-surface temperature, therefore, may affect the thermal regimen of permafrost at different rates in areas having different geologic conditions.

The geologic history of landforms and deposits of Quaternary age is important to local configuration of permafrost. Ground-surface temperature is influenced by: Changes in erosion or deposition of sediments; lateral migration of rivers; formation and drainage of lakes; advance and retreat of glaciers; and changes in climate, vegetation, and snow cover. Although the thermal regimen of permafrost is largely a product of changes in the ground-surface temperature that have taken place over the last hundreds or few thousands of years, ground temperature at depth in many parts of Alaska has not yet warmed sufficiently to thaw relict permafrost that was formed during the Wisconsin Glaciation (Hopkins and others, 1955). At Nome, for example, the post-Wisconsin climatic warming 9,000 to 10,000 years ago had degraded only the upper 10 feet of the permafrost formed in Wisconsin time, and subsequent climatic cooling has formed new permafrost (Hopkins and others, 1960). Similarly, at Fairbanks, permafrost of Illinoian age was largely degraded during the Sangamon Interglaciation (Péwé, 1958a) but permafrost was formed again under the rigorous climate of Wisconsin time. Preservation of flesh and hide of large mammals in frozen deposits of Wisconsin age, and degradation of permafrost to a depth of only 3-10 feet during the post-Wisconsin climatic warming $3,500-6,000$ years ago show that much of the existing permafrost was formed in Wisconsin time.

Local configuration of permafrost seems to follow geomorphic boundaries in some deposits of Holocene age that were laid down after degradation of permafrost by a warming influence, such as a river (Péwé, 1947, 1948a). For example, records of borings in the flood-plain and low-terrace alluvium near Fairbanks (fig. 12) show that permafrost thickness increases with increasing age of alluvial surfaces. The correlation is not perfect because of irregularities caused by: (1) Bodies of relict permafrost left undegraded by the migrating river which deposited the alluvium, (2) the thermal effect of forest fires or clearing of vegetation by man, (3) local differences in climate, (4) differences in time since abandonment by the river and removal of its warming effect within the same alluvial surfaces, and (5) the thermal effect of lakes.

Differences in the quantity of heat received from sources within the earth affect the geothermal gradient and the depth to which permafrost will form. Major sources of anomalously high near-surface geothermal heat are from cooling masses of igneous rock and active or dormant volcanoes. Anomalously large regional geothermal gradients are present beneath belts of recently uplifted or folded mountains. Although most of the differences in geothermal heat sources are probably more regional than local in nature, local features, such as thermal springs, provide enough heat to form a zone of unfrozen ground through permafrost and to warm the adjacent permafrost.

\section{APPLICATION OF GEOPHYSICAL METHODS IN DETERMINING LOCAL CONFIGURATION OF PERMAFROST}

The application of geophysical methods to permafrost investigations in Alaska and to problems of lateral variations in the thickness of permafrost has been reported by Joesting $(1941,1954)$, Barnes and MacCarthy (1956, 1964), Crowley and Hanson (1956), Barnes $(1965$, p. 349-355), and in unpub- 


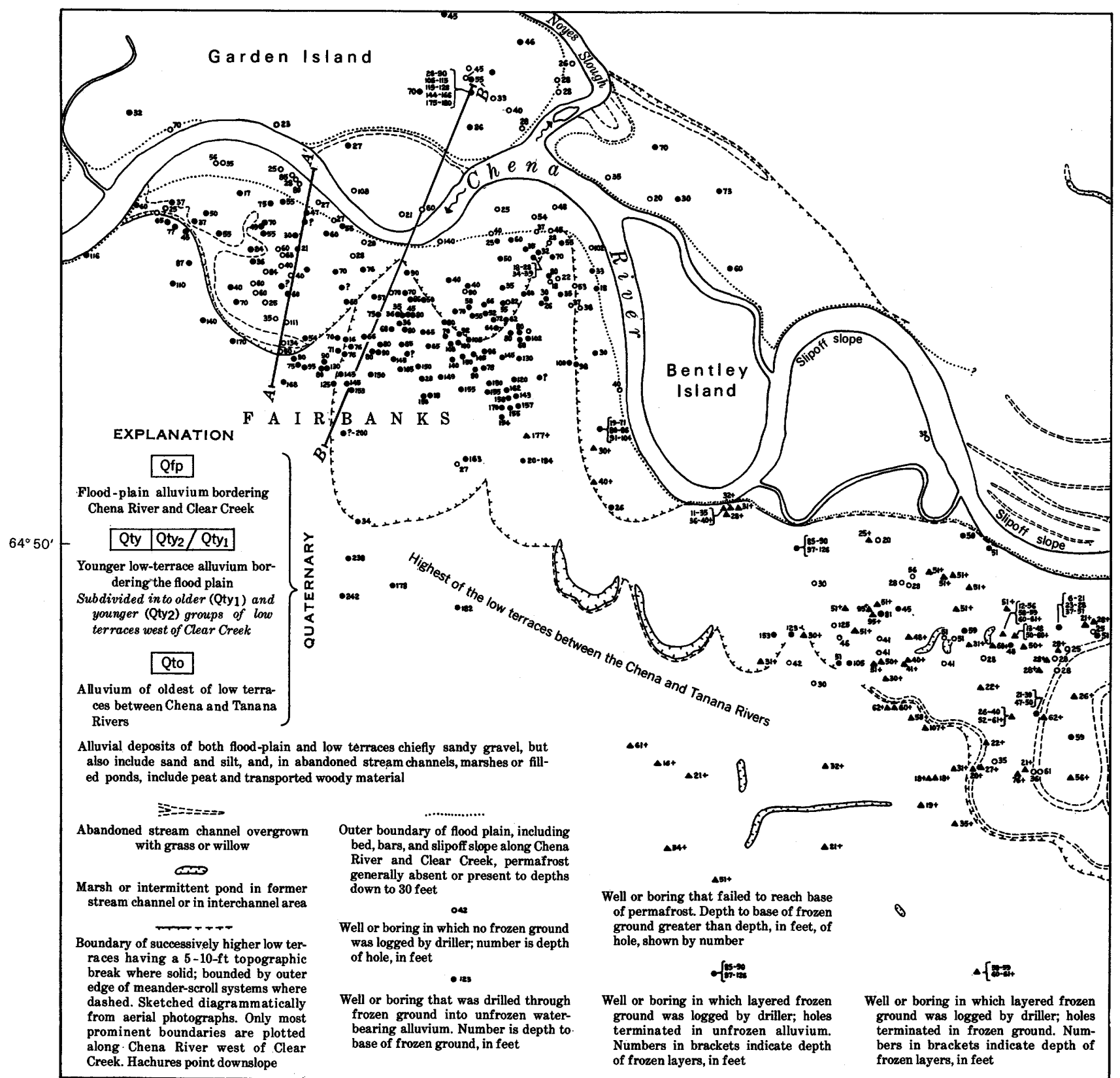

Base modified from U.S. Army Corps of Engineers, 1947, and City of Fairbanks. 1946: abandoned channels, marshes, and intermittent ponds from map by T.L. Péwé. 1947

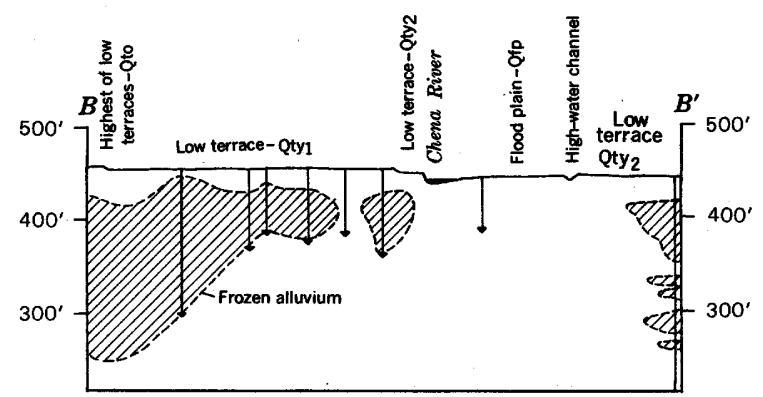

Figure 12.-Map showing depth to base of frozen alluvium in the flood 

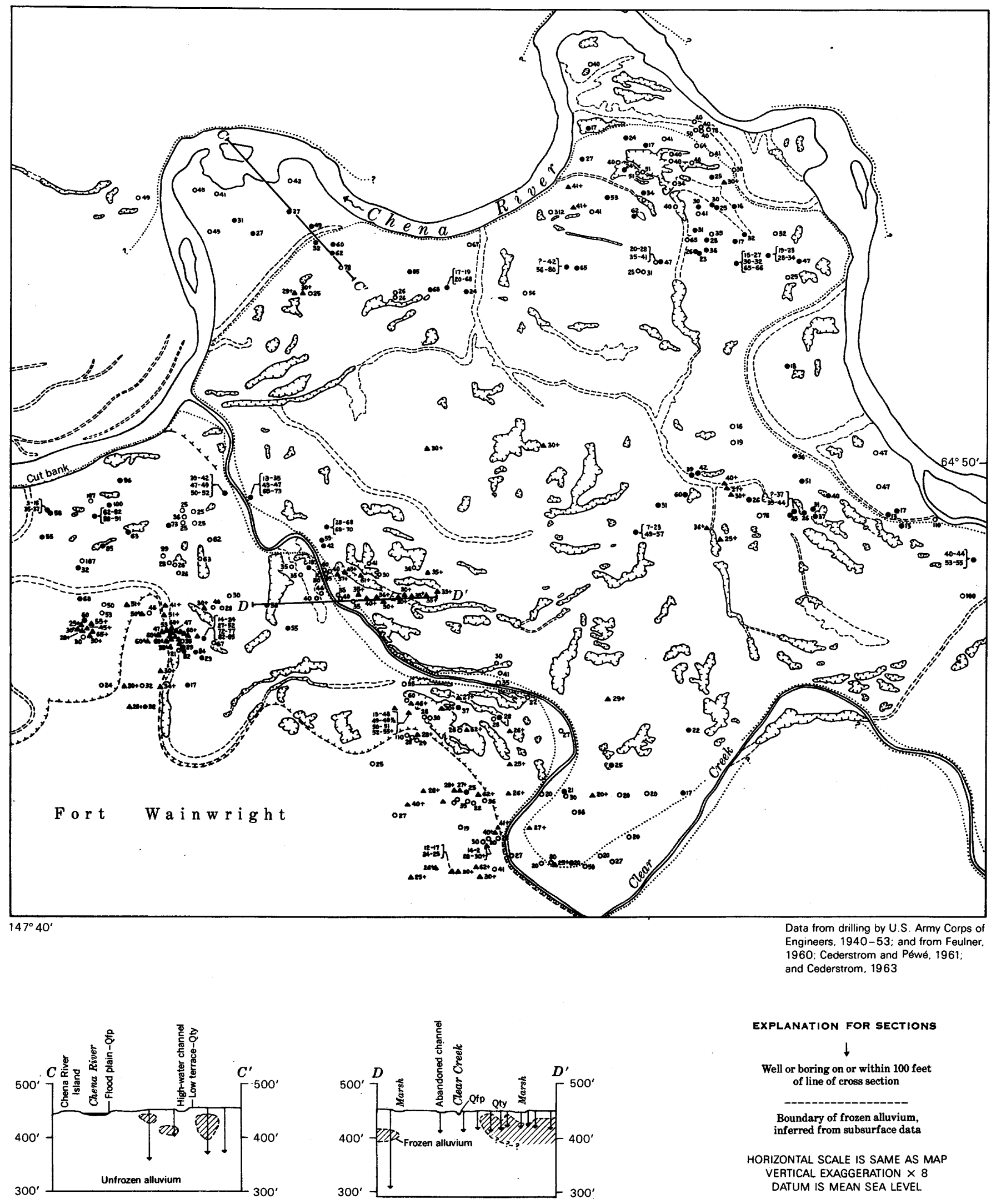

plain and low terraces of part of the Chena River near Fairbanks, Alaska. 
lished papers by MacCarthy and others ${ }^{1}$ and by Swartz and Shepard ${ }^{2}$. These studies showed that the electrical-resistivity and seismic-refraction methods have the greatest potential. The resistivity method indicates the approximate thickness of permafrost, but only if the physical properties of the rock materials are known and subsurface records are available to check the interpretation. The accuracy of this method is limited by inadequate interpretation curves and by the effects of severe lateral variations in surface resistivity (Barnes and MacCarthy, 1956). The method is useful to supplement a drilling program. The seismic-refraction method gives excellent results in delineating the permafrost table, but does not provide information on the base (Barnes and MacCarthy, 1956; Crowley and Hanson, 1956). This method is particularly useful in determining the depth to the permafrost table beneath lakes and rivers and has been used in Canada for such purposes (R. J. E. Brown, oral commun., 1963).

Other methods, not yet tested in Alaska, are the electromagnetic methods used in the Soviet Union (Petrovskii and Dostovalov, 1947) and the gravity methods used to detect differences in density of frozen ground, such as those caused by large bodies of ground ice (Bulmasov, 1957). Heat-sensing techniques using ultrared and ultraviolet photography (Frost and others, 1965) are not yet fully developed for application to permafrost problems.

\section{EFFECT OF PERMAFROST ON GROUND WATER}

Ground water in unfrozen unconsolidated deposits and bedrock above, within, and beneath permafrost is called, respectively, suprapermafrost, intrapermafrost, and subpermafrost water (Tolstikhin, 1941; Cederstom and others, 1953, p. 6-10). Although the ice content of permafrost is considered ground water in some Russian classifications (Tolstikhin, 1941; Tolstikhin in Sumgin and others, 1940 ), it is excluded by others (Meister, 1955). In North America, ground ice has been excluded from the field of ground water (Meinzer, 1923, p. 22). The effects of permafrost on the ground-water regimen are discussed below.

\footnotetext{
1 MacCarthy, G. R., and others, 1952, Geophysical methods of prospecting for ground water in permafrost regions, v. 3, Ground-water development in the Arctic: Unpub. rept. prepared by Geophysics Branch, U.S. Geol. Survey for Engineer Research and Development Lab., U.S. Army, Fort Belvoir,
Va., $186 \mathrm{p}$.

${ }^{2}$ Swartz, J. E., and Shepard, E. R., 1946, Report on a preliminary investigation of the possible applications of geophysical methods to studies of permafrost problems in Alaska: U.S. Bur. Mines, Div. Geophysical Explor.,
}

\section{RECHARGE}

Recharge of ground water is principally from infiltration of rainfall or snowmelt, or from bodies of surface water. As water percolates downward, it is blocked at the permafrost table. A shallow permafrost table holds perched water near the surface, and this accelerates evaporation and transpiration during the summer. The high water table in the area of a shallow permafrost table is favorable for growth of muskeg and marsh vegetation. Numerous small lakes are formed in lowlands where drainage is impeded by fine-grained soils, low hydraulic gradient, and luxuriant growth of muskeg and marsh vegetation. Poor drainage caused by near-surface permafrost is not limited to lowlands, but is also characteristic of many. slopes, particularly in the tundra region of northern and western Alaska.

Water reaches aquifers at depth only through unfrozen areas that perforate the permafrost, such as those beneath streams, lakes, and summits and slopes of low hills. Suprapermafrost water migrates laterally on the slope of the permafrost table until it discharges at the surface or reaches an unfrozen zone. If the suprapermafrost water reaches the unfrozen zone at a level that is above the level of the water beneath permafrost, it moves downward as intrapermafrost water until it reaches the water level of the subpermafrost aquifer.

Precipitation falls as snow on the frozen ground surface in winter; therefore, at that time precipitation does not usually recharge the ground water above the permafrost. However, water may continue to move from the suprapermafrost zone downward to recharge subpermafrost aquifers until seasonal frost reaches the permafrost table or some other impermeable layer. In winter, water levels normally decline as the flow of surface water ceases. The late-winter base flow of rivers is discharge of ground water stored in permeable material along riverbanks or from perennial springs. Streams that are fed in winter by ground-water discharge in their upper reaches may continue to recharge ground water in their lower reaches at a reduced rate.

\section{MOVEMENT}

Permafrost acts as a barrier to the downward percolation of water that would normally recharge aquifers; it also blocks lateral movement of water, and acts as an impermeable confining layer to subpermafrost water. Confined subpermafrost water generally has an equipotential surface within the permafrost zone, but in some places, its static level is above land surface. 
Because the velocity is inversely proportional to viscosity, the rate of ground-water flow tends to be lower in permafrost regions than in comparable material in temperate regions. The viscosity of water at $0^{\circ} \mathrm{C}-4.5^{\circ} \mathrm{C}$ is $20-50$ percent higher than at the prevailing temperatures in temperate regions.

\section{DISCHARGE}

Natural discharge of ground water in permafrost regions takes place, as in temperate regions, where the water table intersects the land surface; it is usually discharged in valleys, along coasts, and in other topographically low places. In winter, sites of ground-water discharge are readily identified by icings, also called aufeis fields. Icings are masses of surface ice as much as 20 feet thick that are formed by freezing of successive thin sheets of water seeping from the ground, rivers, and springs (Chekotillo, 1940). Persistent activity of icings throughout the winter indicates perennial discharge of ground water (Hopkins and others, 1955). Springs in permafrost regions are fed by discharge of either suprapermafrost or subpermafrost water. Discharge of subpermafrost water is generally perennial, but that of suprapermafrost water is intermittent and is limited in some places to the summer months and in others to the winter months.

Large, conical, ice-cored hills called pingos are a special structural feature related to ground-water discharge and hydrostatic pressure in permafrost regions (Leffingwell, 1919; Porsild, 1938; F. Müller, 1959; Holmes and others, 1965; Mackay, 1965). Pingos are formed by arching of the ground surface caused by hydrostatic pressure of ground water confined by permafrost. The pressure ruptures the summit of some pingos and the cracks thus formed either are occupied by small ponds or are the sites of springs. The presence of springs indicates continued relief of hydrostatic pressure by discharge of confined water. Many pingos are relict features that indicate hydrostatic pressure and ground-water discharge in the recent geologic past; others, actively forming, indicate the existence of confined ground water. Two types of pingos are : (1) The open-system pingos produced by confined subpermafrost water in the discontinuous zone discussed by Holmes, Hopkins, and Foster (1965) and (2) the closed-system pingos produced by confined intrapermafrost water in the continuous-permafrost zone described by Müller (1959) and Mackay (1965).

\section{SUBPERMAFROST WATER}

An unfrozen conduit is required for surface discharge of water from beneath permafrost. Once established, the perennial flow of water at a temperature above freezing keeps the conduit open. Subpermafrost water is discharged at the surface through fractures and faults in bedrock, cavernous zones in limestone, large openings in volcanic rocks, and permeable unconsolidated deposits. Some subpermafrost water may be discharged into alluvial deposits along streams where the water maintains an ice-free reach during the winter, or water may be discharged along the banks and may flow over the river ice to form extensive flood-plain icings. Some of the largest icings in Siberia and in North America are formed downstream from perennial springs of subpermafrost water.

Subpermafrost water is generally fresh, indicating that it is recharged from the surface and that it circulates. However, brackish and saline water beneath the permafrost has been found in the coastal regions of western Alaska, the Arctic Coastal Plain, the foothills of the Brooks Range, and the Copper River Lowland.

\section{SUPRAPERMAFROST WATER}

Springs that discharge suprapermafrost water in summer commonly cease flowing in winter when the source of water becomes frozen, when water in storage is depleted, or when freezing blocks or diverts the flow. Flow of these springs may continue into early winter, and their discharge freezes at or downstream from the spring orifices to form icings. Icings of intermittent springs no longer form during early winter, but those of perennial springs remain active throughout the winter.

Winter discharge of suprapermafrost water in places that do not have springs in summer is caused by downward extension of seasonal frost into the suprapermafrost aquifer. As freezing extends downward toward the permafrost table or an impermeable layer, suprapermafrost water becomes confined if there is no permeable unfrozen zone available for relief of hydrostatic pressure downward or laterally. The water may be subjected to such great hydrostatic pressure that it ruptures the seasonally frozen layer and seeps out at the surface to form icings. The water may arch the ground as it freezes to form ice-cored frost mounds, which are similar to, but much smaller than, pingos.

Icings in riverbeds or flood plains and icing mounds (an arching of the ice cover) are formed at constrictions in the channel or in the alluvium 
through which ground water moves as underflow. The reduction of the cross-sectional area available for flow forces water to the surface. This reduction can be caused either by deep freezing of the upper surface of the steam or by accumulations of anchor ice or frazil ice beneath the ice cover. Constrictions in underflow are caused by thinning of the alluvium at places where an impermeable barrier, such as a clay or silt lens or bedrock ledge, is near the surface and by freezing of the upper part of the riverbed alluvium. Explosive relief of pressure has been noted in some icings in the Soviet Union (Petrov, 1930, 1934; Chekotillo, 1940).

Suprapermafrost water moving as underflow in a tributary bed or issuing from a riverbank may form local ice-free reaches where the water is above the freezing point. The Tanana River at Big Delta (fig. 5), for example, is kept ice free in winter by discharge of water stored in alluvium along its banks and by discharge of underflow of the Delta River, a large tributary.

\section{STORAGE}

In many areas, permafrost renders useless the near-surface aquifers which are major sources of ground water in temperate regions. In areas where permafrost is absent, storage of ground water may be limited by deep penetration of winter frost. Changes in the local configuration of permafrost that are induced by natural or artificial means may increase or decrease the volume of unconsolidated deposits or bedrock in which water may be stored. For example, at Selin Creek near Cape Lisburne, induced thawing of frozen alluvium has increased the volume of ground water in storage by several hundred thousand gallons over a period of 10 years (Feulner and Williams, 1967, p. B201).

The extent of permafrost in alluvium has an important effect on the volume of ground-water storage that is the source of winter streamflow. Although streamflow data are meager for the northern part of the discontinuous-permafrost zone and absent for the continuous zone, the extent of permafrost in a basin is probably one of the most important factors in determining the base flow of streams and whether the stream is perennial or intermittent.

\section{OCCURRENCE OF GROUND WATER}

The following summary describes the occurrence of ground water in relation to permafrost at localities in Alaska that are grouped by similar geologic environments. The several environments (fig. 2) are: (1) Alluvium of river valleys, including the flood plains, terraces, and alluvial fans of both major valleys and smaller mountain and upland valleys, (2) glacial and glaciolacustrine deposits of the interior valleys, (3) coastal-lowland deposits of northern and western Alaska, including bars, spits, and beach and delta deposits, and (4) bedrock of uplands and mountains. Eolian deposits, chiefly dune sand, are shown in figure 2 in the major valleys and are discussed with alluvial deposits wherever pertinent. The discussions include virtually every area for which ground-water-permafrost relations in Alaska are known.

\section{ALLUVIUM OF RIVER VALLEYS}

Alluvial deposits in river valleys are the sources of the largest and most economically developed supplies of ground water in Alaska. The deposits, consisting of permeable sand and gravel, range in thickness from a few feet in small mountain valleys to an estimated 820 feet in the Tanana valley near Fairbanks (Barnes, 1961).

The volume of water stored in alluvial deposits depends on the porosity of the deposit and on the relation between its thickness and extent, the thickness and extent of perennially frozen ground, and the depth of winter freezing. If the lower limit of frozen ground is below the base of the alluvium, as in the continuous-permafrost zone, ground water is limited to shallow unfrozen alluvium in depressions in the permafrost table beneath lakes and rivers. If the frozen zone does not extend to the base of the alluvium, or if the unfrozen zones are extensive and deep, as in much of the discontinuous zone, groundwater storage is generally large in the thick alluvium of major valleys, but much smaller in the thinner alluvium of mountain and upland valleys. Winter freezing of the upper part of the thin alluvial aquifers of small river valleys has a proportionately greater effect on ground-water storage than freezing of the upper part of thick aquifers of large valleys.

The volume of water in alluvium available for discharge to rivers to maintain winter flow depends, in part, on the extent to which the alluvium is frozen. In the continuous-permafrost zone, where unfrozen alluvium is limited to riverbeds and to local unfrozen zones along the bank, ground-water discharge is insufficient to maintain winter flow, in even the largest rivers. Winter flow from storage in lakes and from perennial springs is maintained by some of the rivers of the continuous-permafrost zone. In the discontinuous zone, where the extent of 
frozen alluvium is less and the volume available for storage in unfrozen alluvium is much larger, most rivers maintain flow throughout the winter. The winter flow from ground-water discharge seems to increase southward, consistent with the regional zonation of permafrost.

FLOOD-PLAIN AND TERRACE DEPOSITS OF CONTINUOUS-PERMAFROST ZONE

Shallow perennial or seasonal aquifers in unfrozen alluvial deposits beneath rivers and lakes are the only known sources of potable ground water, other than springs, in that part of the continuous-permafrost zone draining to the Arctic Ocean. In that region, ground water in bedrock beneath 500 to at least 1,330 feet of permafrost is commonly brackish or saline. In that part of the continuous zone south of the Brooks Range, the shallow alluvial aquifers beneath streams and lakes provide the most economically developed sources of water, although fresh subpermafrost water has been reported in terrace alluvium of some of the larger valleys. The aquifers beneath rivers provide larger supplies of better quality water than those beneath lakes.

Icings that form each winter in river flood plains indicate the streamflow or underflow through unfrozen riverbed alluvium continues long after freezeup. The largest icings, active all winter, are formed downstream from perennial springs in the eastern Brooks Range (fig. 5). No information is available on the hydrology of the icings, nor on the depth of perennially unfrozen alluvium beneath the rivers where they form.

Although there are no water wells in the continuous-permafrost zone north of the Brooks Range, available data show that ground water is present in unfrozen alluvium beneath the Colville River, but is less abundant and only seasonal beneath Ogotoruk Creek, Shaviovik River, and Selin Creek. Methods used to increase winter ground-water storage in the alluvium beneath Selin Creek may be applicable in developing water supplies in alluvium beneath other streams. Perennial water supplies from alluvium are probably more common, and the volume of unfrozen alluvium available for storage is probably greater, in the valleys south of the Brooks Range than in those north of the range.

Colville RIVER AT UMIAT

The Colville River flows in a braided channel on a bed of gravel through the Arctic Foothills (fig. 2) and on a bed of fine gravel, sand, and silt across the Arctic Coastal Plain. Discharge measurements in
1953 at Umiat, in the foothills, showed that the river had no flow in April and a flow of 13,000 cfs (cubic feet per second) in September (U.S. Geological Survey, 1958, p. 208).

Umiat is on a low terrace north of the river (fig. 13). Records of seven seismic shotholes (Black and Barksdale, 1948) and five test wells drilled for oil (Collins, 1958a) within 1,750 feet of the river showed that the thickness of terrace alluvium in these holes ranges from 23 to 71 feet and that permafrost extended into bedrock to a depth of as much as 800 feet (table 1). Water-bearing unfrozen sandy gravel was found within the terrace deposits (table 1 , well 5 , holes 5 and 6 ). Winter thermal studies made beneath a deep lake on the terrace and beneath the Colville River near Umiat (Brewer, $1958 \mathrm{~b}$, figs. 8 and 9) indicated that the terrace alluvium beneath the lake and alluvium beneath the river had a temperature above $0^{\circ} \mathrm{C}$. Large supplies of ground water are available from the unfrozen alluvium beneath the river; smaller quantities are available from alluvium beneath the lakes that do not freeze to the bottom in winter and from local unfrozen zones in the terrace alluvium near the river (Black and Barksdale, 1948; Williams, 1970). Ground water may occur in similar alluvial deposits elsewhere in the Colville River valley and beneath other large rivers draining to the Arctic Ocean.

\section{SHAVIOVIK RIVER VALLEY}

Thermal measurements were made in 1953 in a 135-foot boring made on a sandbar in the middle of West Fork Shaviovik River (fig. 5, approx lat $69^{\circ} 30^{\prime}$ N., long $146^{\circ} 40^{\circ}$ W.) and in borings beneath the tundra on opposite sides of the river a quarter of a mile from the bar (Brewer, 1958b, p. 26, fig. 10). Results showed that permafrost is more than 135 feet thick and seasonal frost extended to the permafrost table beneath this intermittent river. Because of the warming effect of the river during its period of summer flow, the permafrost beneath the bar was $3^{\circ} \mathrm{C}$ warmer than that in the borings on both sides of the river. The studies showed that unfrozen alluvium is thin, but that it contains water in summer. Ground water is not available from the alluvium beneath the bar throughout the winter.

\section{Ogotoruk Crgek NEAR CAPE ThOMPSON}

Ogotoruk Creek is a small intermittent stream that empties into the Chukchi Sea 6 miles southeast of Cape Thompson. The creek has little or no flow from October to May (Slaughter, 1961, p. 94; U.S. Geological Survey, 1963a, p. 123-124; 1963b, p. 133). It flows through a narrow flood plain in a 
TABLE 1.-Data on permafrost and ground

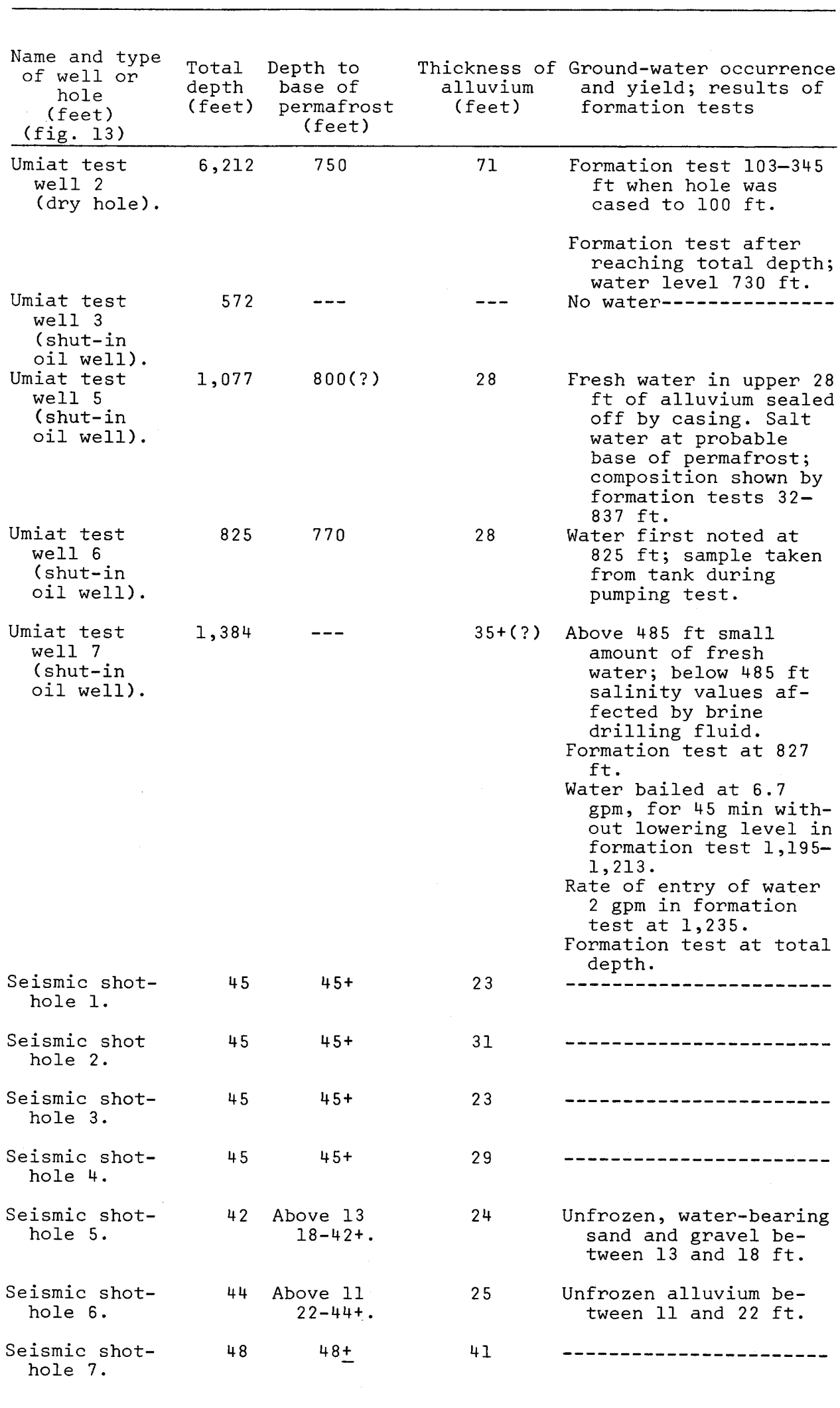

\footnotetext{
${ }^{1}$ Analyses by U.S. Bur. Mines.
} 
water in the Colville valley at Umiat

\begin{tabular}{|c|c|c|c|c|c|c|c|c|c|}
\hline $\mathrm{Ca}$ & $\mathrm{Mg}$ & $\mathrm{Na}$ & $\mathrm{HCO}_{3}$ & $\mathrm{SO}_{4}$ & $\mathrm{Cl}$ & Other & $\begin{array}{l}\text { Total } \\
\text { solids }\end{array}$ & Salinity & $\begin{array}{l}\text { Sources of in- } \\
\text { formation for } \\
\text { quality of } \\
\text { water }\end{array}$ \\
\hline 243 & 1 & 244 & 0 & 5 & 173 & $\begin{array}{ll}142 \mathrm{CO} \\
223 \mathrm{OH}\end{array}$ & 1,031 & -- & $\begin{array}{l}\text { Collins (1958a, } \\
\text { p. 99-116). } \\
\text { Reed (1958a, } \\
\text { p. 78). }\end{array}$ \\
\hline 64 & 13 & 1,022 & 865 & 21 & 1,176 & $\begin{aligned} 27 \mathrm{CO}_{3} \\
0 \mathrm{OH}^{3}\end{aligned}$ & 3,188 & -- & \\
\hline--- & -- & --- & --- & --- & -- & --- & --- & --- & $\begin{array}{c}\text { Collins (1958a, } \\
\text { p. 116-125). }\end{array}$ \\
\hline--- & -- & --- & --- & --- & --- & -- & --- & $\begin{array}{l}62,900 \text { after } \\
11 / 2 \mathrm{hr} \\
\text { pumping } \\
19,400 \mathrm{af}- \\
\text { ter } 41 / 2 \\
\text { hr pump- } \\
\text { ing. }\end{array}$ & - \\
\hline
\end{tabular}

$\begin{array}{lllllll}15 & 20 & 2,450 & 3,350 & 685 & 1,400 & \cdots\end{array} \quad 7,928$

Brewer, p: 142,
in Collins
(1958a); Col-
lins (1958a,
P. 132-142).
Colins (1958a,
p. 143-148).

in Collins
(1958a); Col-
lins (1958a,
p. $132-142)$.
lins (1958a,
p. 143-148).

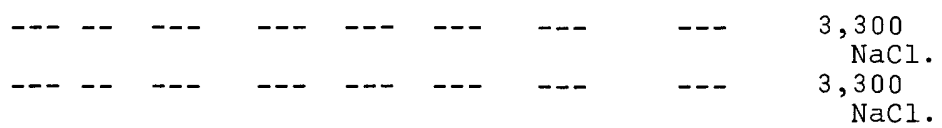

$--\cdot-\cdot--\cdot--$

- - - - - - - - -

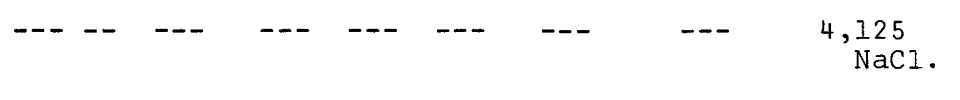

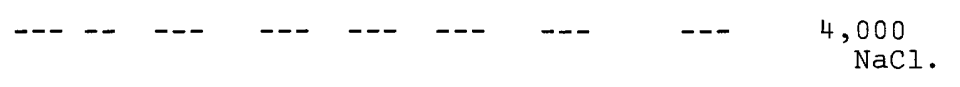

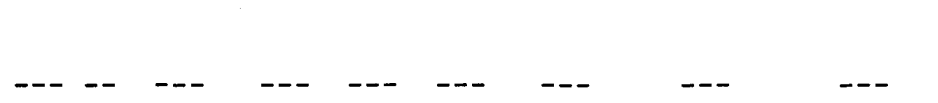

-- -- -- --

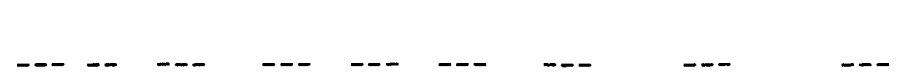

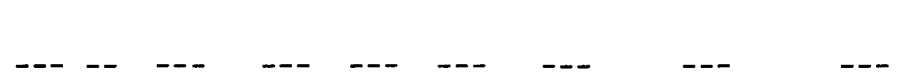

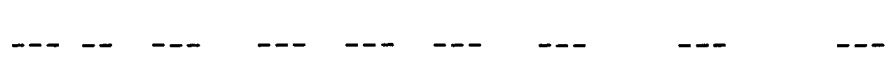

Black and Barksdale $(1948)$, hole 1, p. 14 .

Black and Barksdale (1948), hole 2, p. 14.

Black and Barksdale (1948), hole 3, p. 14.

Black and Barksdale (1948), hole 4, p. 20.

Black and Barksdale (1948), hole $5, \mathrm{p} .12$, 20 , and fig. 2 . Black and Barksdale (1948), hole $6, \mathrm{p} .20$. Black and Barksdale (1948), hole $7, \mathrm{p} .20$ 


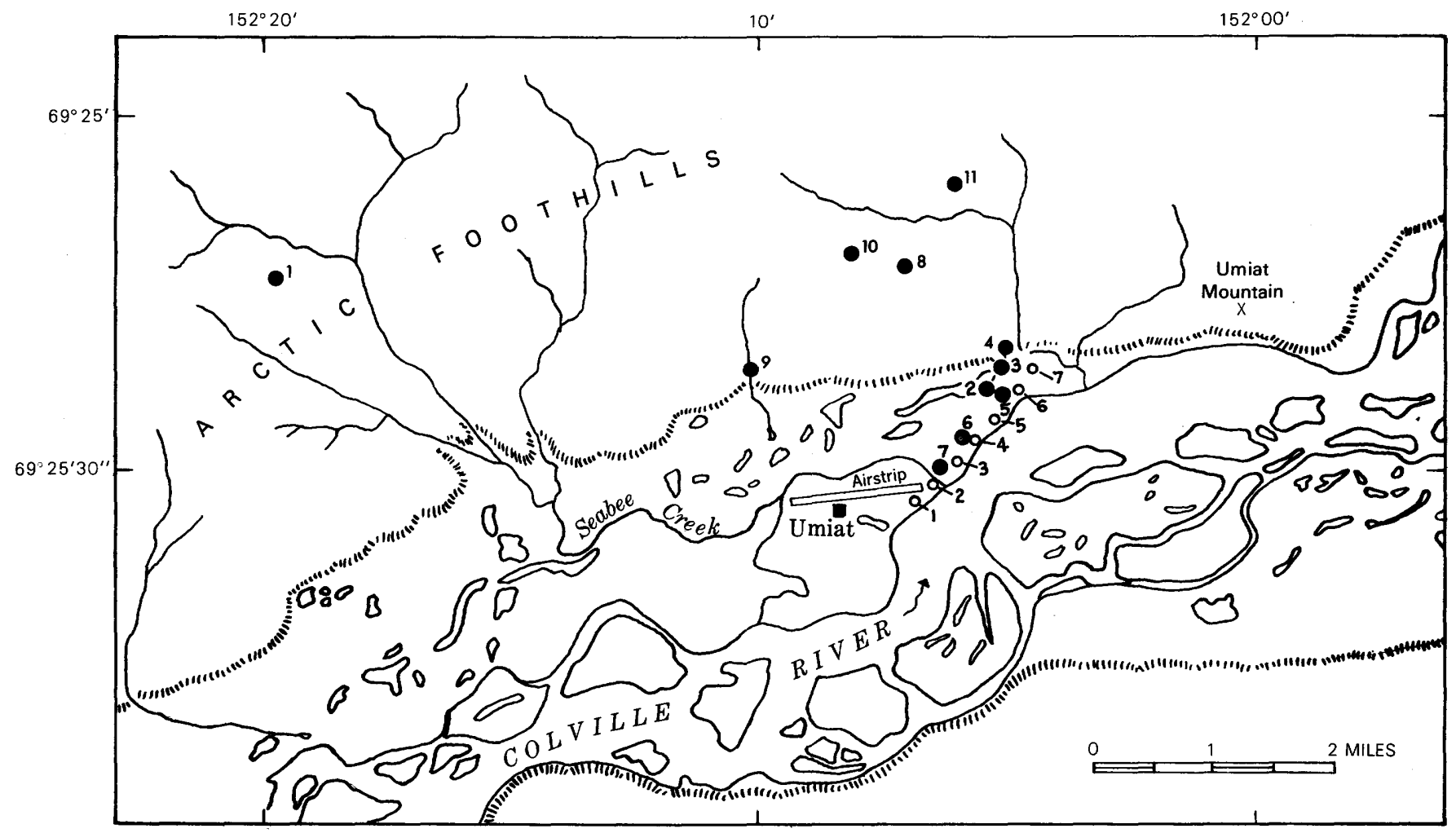

\section{EXPLANATION}

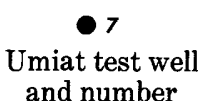
01
Seismic shot hole and number

Figure 13.-Location of wells, Umiat area.

broad valley that is underlain by nearly impermeable siltstone. The flood-plain alluvium is locally more than 8 feet thick and consists of sand, gravel, and boulders (Waller, 1960a). Permafrost in bedrock beneath the valley has been measured to depths as great as 1,170 feet (Lachenbruch and others, 1961, p. 66, fig. 11). The depth of the permafrost table beneath the creek was not recorded, but locally it lies below the depth to which winter freezing penetrates (Waller, 1962). In other parts of the flood plain, seasonal freezing extends to the permafrost table, and the alluvium is frozen from the surface to its contact with the underlying siltstone.

Availability of a year-round supply of water from the alluvium beneath Ogotoruk Creek depends on thickness of the alluvium in relation to the depth of winter freezing, the depth to siltstone, and to the position of the permafrost table. When the creek is at a high summer stage, unfrozen alluvium beside and beneath the creek is recharged by the creek (Waller, 1962). At the onset of the freezing season, the stage of the creek falls, and flow is maintained by discharge of ground water stored in unfrozen alluvium. If the winter is mild and the snow cover is thick, flow and underflow are not interrupted. However, if freezing is rapid, streamflow and underflow are constricted, causing icings and icing mounds along the creek. A small amount of ground water may be available locally throughout all or part of some winters but not others. Thus, the alluvium is a small aquifer which varies in storage capacity with the depth of winter freezing.

\section{Selin Creek near Cape Lisburne}

Selin Creek is a $21 / 2$-mile-long intermittent stream that empties into the Chukchi Sea 3 miles east of Cape Lisburne. Under natural conditions, the permafrost table in the alluvium is 6-8 feet below the streambed and less than 2 feet below the tundra-covered flood plain bordering the stream. Freezing probably extends to the permafrost table by late winter, and water is available from the creekbed alluvium only in summer and early winter. 
Several unsuccessful attempts were made to obtain a reliable water supply in this area over a 10-year period. Finally a ground-water reservoir that contained water in late winter was developed by lowering the permafrost table in the alluvium and reducing the depth of penetration of winter freezing (Feulner and Williams, 1967, p. B199201). The methods used to lower the permafrost table were: (1) Stripping the tundra vegetation and upper few feet of the creekbed alluvium to increase the amplitude of seasonal temperature changes, (2) constructing a dam and reservoir to recharge warm surface water in summer by leakage into the alluvium, and (3) installing infiltration galleries downstream from the dam to increase water circulation through the alluvium. To retard the penetration of winter freezing, snow fences were erected to provide an insulating snow cover over the gallery. Pumping the gallery after cessation of streamflow to dewater the upper part of the alluvium provided an unsaturated, seasonally frozen, permeable zone through which the early spring melt water could percolate to the aquifer. The success of these methods depended upon the presence of an impermeable silt lens above which a snow-free road fill was constructed across the creek below the gallery. The silt lens and deep freezing in winter beneath the road fill prevented downvalley flow of ground water stored in the alluvium between the seasonal frost and the permafrost table. The methods used at Selin Creek may be applicable to other rivers and small streams in the continuous-permafrost zone.

\section{KobUK, KoYUKUK, AND CHANDALAR RIVER VALLEYS,} SOUTHERN BROOKS RANGE

The Kobuk, Koyukuk, and Chandalar Rivers and some of their large tributaries in the southern part of the continuous-permafrost zone are underlain by unfrozen, water-bearing alluvium. The unfrozen zones are apparently much thicker and more extensive areally than those in valleys north of the Brooks Range. The terrace and alluvial-fan deposits, remote from large rivers, are generally frozen.

Unfrozen alluvial aquifers have been reported in the Kobuk drainage basin beneath the beds of California, Lynx, and Dahl Creeks near Kobuk and beneath the Shungnak River (fig. 4) (Smith and Eakin, 1911; Smith, 1913; Moffit, 1927). However, Cathcart (1920) reported that the alluvium beneath California Creek is locally frozen. Unfrozen ground is common near the large sulfide ore body along Ruby Creek, 14 miles north of Kobuk (Chadwick,
1960). Although unfrozen in some places, the thick alluvium beneath Squirrel River, north of Kiana, is generally frozen (Smith, 1913).

Records of prospect shafts on lower Hammond River, a west tributary of Middle Fork Koyukuk River near Wiseman, show that the terrace deposits bordering the flood plain were frozen to bedrock at a depth of 90 feet. Shafts dug at mining claims in the flood plain of lower Hammond River entered unfrozen, water-bearing gravel at a depth of 80 feet (Maddren, 1910b; Engineering and Mining Journal, 1915).

In the Chandalar drainage basin, prospect holes in the valleys of Big Creek and Little Squaw Creek near Chandalar (fig. 5) show that the distribution of frozen creek alluvium and subjacent glacial deposits is very irregular (J. B. Mertie, Jr., U.S. Geol. Survey, unpub. data, 1923). Shafts exposed both unfrozen and frozen ground on Big Creek. On Little Squaw Creek, where frozen ground in one shaft extended to a depth greater than 110 feet, a drift dug from the shaft along the paystreak reached unfrozen alluvium. In other shafts on this creek, the ground is frozen to a depth of about 20 feet, and unfrozen below that depth. In one shaft, located on a bench, water stood 20 feet above the bottom of the shaft in summer but drained in winter. In another shaft near the creek, the alluvium contained water throughout the winter. Prospecting for ground water in valleys such as these is complicated by the stratigraphy of permeable alluvium and relatively impermeable glacial deposits as well as by the irregular distribution of frozen zones.

In many of the hanging valleys tributary to glaciated sections of the Chandalar and Koyukuk River valleys, till or glaciolacustrine deposits are underlain by alluvium that fills narrow preglacial bedrock valleys. Prospect shafts that had been dug in search of placer gold in the alluvium of some of these buried channels passed through the base of frozen ground into unfrozen water-bearing alluvium just above the bedrock (Maddren, 1913). Such shafts were dug: (1) Through 200 feet of frozen ground on Dictator Creek, tributary to Middle Fork Chandalar River, (2) on Marion Creek, tributary to Middle Fork Koyukuk River, and (3) at a site 4 miles above Coldfoot (fig. 5) (Maddren, 1913; Engineering and Mining Journal, 1915). In other valleys, the glacial, glaciolacustrine, and underlying alluvial deposits are frozen to bedrock, or the frozen glacial and glaciolacustrine deposits rest directly on the bedrock surface. These deposits, for example, are frozen 113 feet to bedrock on Minnie Creek, 
across the Middle Fork Koyukuk River from Wiseman, and to a depth of more than 365 feet on lower Nolan Creek at Nolan (fig. 5) (Maddren, 1913). Shafts have also been dug 150 and 230 feet in the Wild River drainage basin (fig. 4) (Engineering and Mining Journal, 1915) and to depths of 172 and 286 feet in the Chandalar River basin (Maddren, 1913), apparently without reaching the base of frozen ground.

It seems impossible to make meaningful generalizations from such records, because it would be necessary to explore each site individually where water is wanted. The significance of the data, however, is that ground-water supplies can indeed be obtained in some places, and, considering the wide variations reported from small areas, that unsuccessful exploration for perennial ground water at one site does not necessarily indicate that nearby sites are also barren of a year-round water supply. Development of quick and inexpensive methods of prospecting is needed.

\section{Northern Seward Peninsula}

The northern Seward Peninsula, like the southern Brooks Range, lies along the southern margin of the continuous-permafrost zone. Records of mine shafts from this area show that the maximum known thickness of frozen ground is 260 feet (fig. 3) ; however, no temperature data are available. The alluvial deposits are perennially frozen nearly everywhere except beneath and near lakes and channels of perennial and some intermittent streams (Hopkins, Karlstrom, and others, 1955, p. 121). Flood-plain icings associated with springs at the margins of valleys or icings located at places where the shallow bedrock forces underflow to the surface are useful guides for locating ground water (Hopkins, Karlstrom, and others, 1955, p. 121). Limited supplies of ground water are available from unfrozen alluvium beneath lakes.

FLOOD-PLAIN AND TERRACE DEPOSITS OF MAJOR VALLEYS OF DISCONTINUOUS-PERMAFROST ZONE

Abundant supplies of ground water are available from permeable sand and gravel above and below frozen alluvium and in unfrozen zones in valleys of the discontinuous-permafrost zone. Because of higher ground-surface temperatures, permafrost in the discontinuous zone is thinner, less extensive, and more readily affected by the heat transmitted by bodies of surface water than permafrost in the continuous zone. In addition, the known thickness of alluvium in the discontinuous zone is generally greater than in valleys of the continuous zone; in fact, in many valleys it is thicker than the perma- frost. Therefore, the volume of unfrozen alluvium available for ground-water storage is greater, and the unfrozen zones through which water moves between the surface and the alluvium at depth are more numerous in the discontinuous zone than in the continuous zone.

Local zonation of permafrost, which is strongly influenced by the thermal effect of rivers and lakes, caused recorded differences in permafrost thickness of as much as 400 feet over a horizontal distance of only a few hundred feet. The configuration of permafrost is so variable that it cannot be shown with confidence on maps, even if the subsurface data are closely spaced, such as at Fairbanks (fig. 12).

LOWER AND MIDDLE KOYUKUK RIVER VALLEY

Ground water is available from both flood-plain and terrace alluvium at settlements in the middle and lower Koyukuk River valley. At Bettles airfield (fig. 4), near the northern border of the discontinuous-permafrost zone, six wells, 34-44 feet deep, produce water from coarse unfrozen terrace gravel. At Hughes, farther downstream, on a terrace 15-20 feet above the river, a well 13 feet deep produced water from unfrozen gravel, and a 92-foot well drilled through the unfrozen terrace deposits into bedrock produced $35 \mathrm{gpm}$ (gallons per minute). At Huslia, twenty-nine 2-inch domestic wells, 50-60 feet deep, produce water from unfrozen alluvium. However, at Allakaket, a well was drilled through 90 feet of terrace gravel and into clay without obtaining water; the deposits were frozen from near the surface to a depth of more than 202 feet, at which point the well was abandoned.

\section{YUKON RIVER VALLEY}

Alluvium is probably unfrozen beneath the bed of the Yukon River throughout its course in Alaska. The frozen alluvium is thin in the flood plain adjacent to the river, but the alluvium is probably frozen to greater depths beneath sections of the flood plain and low terraces away from present rivers and lakes. Scattered records show that, locally at least, the frozen ground beneath stabilized sand dunes on low terraces of late Pleistocene or Holocene age is thicker than that beneath adjacent sections of the modern flood plain and that frozen ground is thicker beneath the high terraces than beneath the flood plain. Most of the wells in the Yukon River villages from Canada to the Bering Sea (figs. 4-6) are along the riverbank where the warming effect of the river affects the thickness of frozen ground. Water levels, where observed in these wells, fluctuate with the stage of the river. 
In Eagle, near the Canadian border (fig. 5), water is produced from unfrozen terrace alluvium in a 60-foot dug well. However, ground water was confined beneath 40 feet of frozen alluvium in a prospect shaft on an island in the river near the village (Purington, 1905, p. 158). Downstream, at Circle in the Yukon Flats, frozen ground is thin or absent in alluvium beneath the village which is on a low terrace that has been cleared of vegetation for many years.

Early attempts to obtain water at Fort Yukon from a hole driven to 237 feet beneath the low terrace south of the airstrip (Mertie, 1937) and from holes drilled to depths of 75-440 feet beneath the dunes east of the village were unsuccessful. The 440-foot hole penetrated 48 feet of dune sand, 100 feet of alluvium, and 292 feet of lacustrine (?) silt and silty sand; these deposits were frozen from near the surface to a depth of at least 320 feet and possibly deeper than 393 feet (Williams, 1960, 1962). Shallow wells dug in unfrozen gravel along the riverbank provided the only source of ground water until 1963, when six producing wells were drilled in low terrace alluvium. Five of these wells were reportedly drilled into unfrozen alluvium through frozen alluvium, the base of which ranged from 29 to 130 feet below land surface. The other well, 66 feet deep, was drilled entirely in unfrozen alluvium.

Downstream at Beaver, on a low gravel terrace on the north bank of the river, the alluvium is unfrozen for a distance as much as 100 feet back from the bank (Waller, 1957c). About 150 feet north of the bank, a shaft 25 feet deep failed to reach the base of frozen gravel. In the low-lying area west of the village, a 16 -foot shaft dug in unfrozen alluvium of an abandoned flood-plain channel entered water-bearing gravel at a depth of 12 feet.

A well was dug through 54 feet of frozen alluvium to bedrock in the village of Rampart in the canyon of the Yukon. A 225-foot deep prospect shaft near the village (Hess, 1906, p. 152) and several holes of unknown depth at the abandoned agricultural experiment station across the river reportedly failed to reach the base of frozen ground.

Wells, drilled or dug in alluvium to a depth of as much as 70 feet at Tanana, produced water from unfrozen sand and gravel. Downstream, prospect shafts dug in alluvial deposits along lower Illinois Creek near Kallands and along lower Grant Creek passed through as much as 135 feet of frozen ground, beneath which water was confined in unfrozen alluvium (Eakin, 1912).

Galena and Galena Air Force station are on a low-lying slip-off slope on the flood plain north of the Yukon River. Frozen alluvium forms a wedgeshaped mass that is thin near the river, but thickens to $\mathbf{1 1 0}$ feet in the northern part of the station (Péwé, 1947, 1948a). Ground water confined beneath the frozen ground rises to a static level that is approximately that of water-table wells in unfrozen alluvium. Campion Air Force station, on a high terrace 14 miles east of Galena, is supplied by wells drilled through frozen silt, clay, and sand to a depth of 402-423 feet where they reached unfrozen water-bearing gravel. Water confined beneath the frozen ground rose approximately 150 feet above the base of the permafrost in these wells.

Wells at Kaltag, on a low terrace north of the river, were drilled through frozen silt, sand, and fine gravel to a depth of 70-91 feet where they reached unfrozen gravel in which the water was confined under artesian pressure.

\section{TANaNa RIVER VALley}

Flood-plain and low-terrace alluvium consists of sand containing beds and lenses of silt and gravel in the upper part of the Tanana River valley, and fine to coarse sandy gravel containing beds and lenses of silt and sand in the middle and lower parts of the valley. These alluvial deposits may be unfrozen beneath the channels and bars of the Tanana and its major tributaries, but beneath the low terraces away from the thermal influence of the rivers and lakes, the alluvium is frozen to a known depth of as much as 265 feet. In most areas of the valley, the frozen zone is thin compared to the total thickness of the alluvium. Therefore, the ground-water resources of this valley have been characterized as enormous (Cederstrom, 1952, 1961b, 1963) because of the large storage capacity and high transmissibility of the unfrozen alluvium.

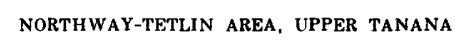
RIVER VALLEY

Frozen ground in wells at Northway airport extends to a depth as great as 90 feet, but in two wells at the northern margin of the valley, near the junction of the airport road and Alaska Highway, the base of frozen ground is 147 and 161 feet below land surface (Waller and Tolen, 1962a). Water in the sand, silt, and gravel, which are more than 246 feet thick at the airport, is confined beneath the base of frozen ground and rises in well casings to a static level approximating that of 
the adjacent rivers. Although frozen ground is absent adjacent to the rivers and is uncommon in alluvium beneath recently abandoned channels, it is common beneath silt-filled channels that have been abandoned for a long time (Wallace, 1946, 1948). Test borings beneath stabilized dunes on a low terrace bordering the flood plain east of the airport penetrated frozen dune sand and alluvium to a depth of 140 feet, a somewhat greater thickness of frozen ground than was penetrated in the airport wells on the flood plain nearby.

At Tetlin, which lies on the banks of Tetlin River between Tetlin Lake and the Tanana River (fig. 8), three wells were drilled through 53-63 feet of silt and clay into sand and gravel. The base of frozen ground is 58-63 feet deep, and water confined in the gravel beneath the frozen ground has a static level that is 15-17 feet below land surface, the approximate level of Tetlin River.

EIELSON AIR FORCE BASE

The base, 26 miles southeast of Fairbanks by road, is on a low terrace northeast of the Tanana River. The surface of the terrace consists of braided channel scrolls and low interchannel ridges marking the position of former bars. The terrace deposits consist of beds and lenses of gravel, sand, and silt. About 3,500 foundation borings and 34 water wells have been drilled on the base by U.S. Army Engineer District Alaska and its contractors. Most of the borings were less than 20 feet deep and did not provide records that enabled distinction between seasonal frost and permafrost. Of the 260 borings and 34 wells that were deeper than 20 feet, only 77 holes were drilled in frozen alluvium; of these, only 32 passed through it into unfrozen alluvium. These records show that the base of permafrost ranges from 17 to 124 feet below land surface. Although the thickest permafrost is in wells in the southeastern part of the cantonment area, apparently no relation exists between the landforms and history of river migration, and the thickness of permafrost.

Foundation studies beneath a new hangar at the Air Force base (Terzaghi, 1952, p. 36) delineated a belt of frozen ground 1,200 feet wide. Beneath one of the abandoned channel scrolls the permafrost table was close to the surface and coincided with the base of seasonal frost, but at the margins of the body of permafrost, the depth to permafrost table declined to 35 feet below land surface. The depth to the base of frozen alluvium over the entire area explored was 60 feet.
Ground water is found under water-table conditions in wells drilled in unfrozen sand and gravel, and is confined beneath the base of frozen alluvium in other wells. The water level and the potentiometric surface coincide about 8-15 feet below land surface and slope northwestward, parallel to the slope of the low terrace on which the Air Force base is situated.

FAIRBAN KS AREA

Alluvial deposits of the Chena and Tanana Rivers in the Fairbanks area consist of beds and lenses of gravel, sand, and silt. These deposits range from a few feet thick near the hills that bound the valley north of the city to an estimated 820 feet thick 2 miles south of the city (Barnes, 1961, p. D257) where the base of the alluvium lies about 350 feet below present sea level. The near-surface alluvium forming the flood plain and the adjacent low terraces is probably of Holocene age. The deeper alluvium which extends to bedrock is probably of Pleistocene age, but its basal part may be of late Tertiary age. The Pleistocene or older deposits were formed during aggradation of the Tanana valley by the Tanana River and its southern glacier-fed tributaries (Mertie, 1937; Capps, 1940; Péwé, 1958a) in a basin that was subsiding in regard to the Alaska Range. North of the Chena River the alluvium is overlapped and interbedded with silt and organicrich silt which were deposited in coalescent alluvial fans by small streams draining the uplands to the north (fig. 14).

The map (fig. 12) of the alluvial deposits of the Chena River valley between Fairbanks and Fort Wainwright shows the location of the flood plain and the distribution of successively older and higher terraces south of the river. The terraces, ranging from a few to about 25 feet above the Chena River, were included in the flood-plain deposits mapped by Péwé (1958a). Most of the terraces shown on the map are composed of numerous alluvial surfaces resulting from cutoff of oxbow bends of the river.

Records of permafrost in the flood-plain and lowterrace deposits at Fairbanks and Fort Wainwright are from about 5,100 wells and borings, of which only 550 reached the base of permafrost. Selected wells and borings, including the deeper holes and all those that penetrated permafrost, were plotted for the 15,000-acre Fairbanks-Fort Wainwright area (fig. 12), and other wells and borings from nearby areas are summarized in table 2 . These records are from drillers' logs, some of which are tabulated by Péwé (1958a), Feulner (1960), Ceder- 


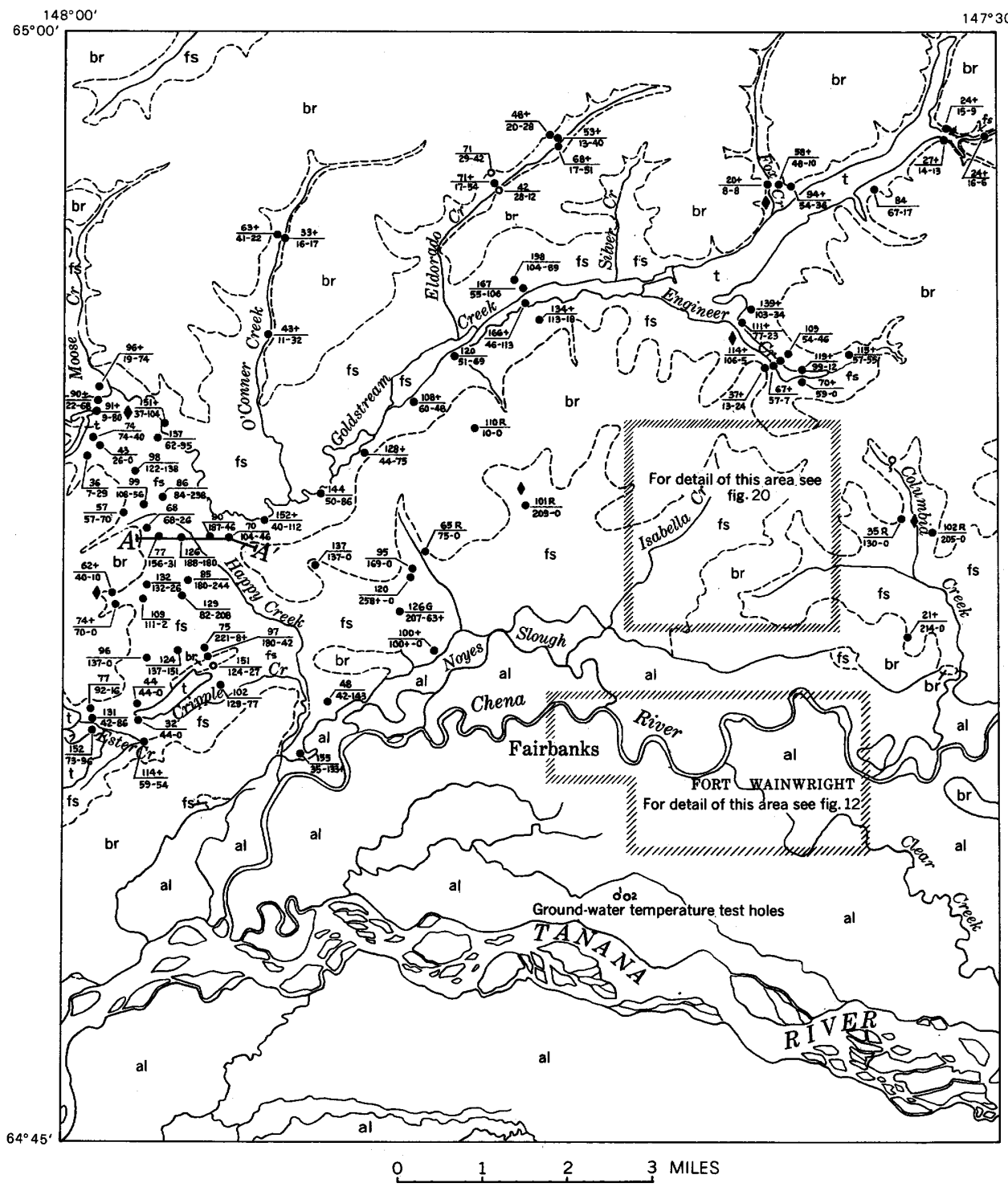

EXPLANATION

Alluvium

Chiefly gravel, sand, and silt of flood plain and low terraces of Chena and Tanana River valleys; frozen and unfrozen

\section{fs}

Perennially frozen silt

Perennially frozen alluvial silt, including some eolion silt, peat, lenses and thin beds of sand and gravel and tabular and polygonal masses of clear ground ice; occurs chiefly in creek valleys of the YukonTanana Upland and along lower courses of streams draining from the upland to Chena River

\section{Placer-mine tailings}

Creek gravel and blocky fragments of bedrock deposited by dredges during placer-mining operations. reportedly locally frozen

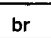

Unfrozen loess-mantled bedrock, undifferentiated

Dominantly Birch Creek Schist, but includes stock and dikes of granitic rock and basaltic lava flows. Overlain by Fairbanks Loess, unfrozen eolian silt on most summits and slopes in central and south ern part of upland within map area

$$
\begin{gathered}
\text { Site of perennial icing } \\
\text { Spring } \\
\circ \frac{100}{58-22}
\end{gathered}
$$

Prospect boring in unfrozen ground Number on upper line total depth of boring, in feet; left-hand figure... lower line is thickness of silt right-hand figure...is thickness of gravel penetrated before reaching bedrock in feet. Plus sign (+) beside figure for thickness of silt or gravel indicates hole failed to reach base of silt or gravel

$$
\text { - } \frac{113}{80.50^{\mp}}
$$

Prospect boring in frozen ground Number on upper line is depth to base of frozen ground, in feet. Plus sign indicates hole failed to reach base of frozen ground. Left-hand number on lower line is thickness of silt penetrated; righthand number is thickness of gravel, in feet. Plus sign used with numbers on lower line indicates hole failed to reach bedrock and terminated in unconsolidated deposits at depth indicated

$$
\text { - } \frac{113 G}{80-50^{F}} \cdot \frac{100 \mathrm{R}}{40-\mathrm{C}}
$$$$
\text { Wells }
$$

Water well producing from gravel $(G)$ or rock $(R)$ below the base of frozen ground, which is depth shown, in feet, on upper line. Left-hand number on lower line is thickness of frozen and/or unfrozen silt; right-hand number is thickness of frozen and $/$ or unfrozen gravel above bedrock, in feet. Plus sign used with thickness of gravel or silt indicates hole failed to penetrate unit at depth indicated

Contact

Dashed where approximately

located

FIGURE 14.-Generalized geology and distribution and thickness of permafrost in part of the Fairbanks mining district. Section $A-A^{\prime}$ shown in figure 19. 
strom and Péwé (1961), and Cederstrom (1963); others are unpublished data supplied by U.S. Army Engineer District Alaska. The records show the depth of the base of frozen ground as logged during drilling. The subsurface data at Fairbanks and Fort Wainright (fig. 12) are insufficient to allow drawing of meaningful contours depicting the configuration of the top, or base, of permafrost. Where the wells are closely spaced, they show extreme variations in permafrost thickness over short horizontal distances. Despite these limitations, some general observations on the range of permafrost thickness within each of the groups of terraces and in the flood plain can be established from the data (fig. 12).

The flood plain at Fairbanks and Fort Wainwright consists of the channel, bars, and small islands of the Chena River and sections of the slipoff slopes on the inside of river meanders. Although subsurface records are not available for the alluvium beneath the river channel, records of holes drilled on the small islands and along the slip-off slope of the river indicate that permafrost is probably absent in the alluvium beneath the channel. Locally, beneath the older part of the slip-off slope and some islands, near-surface permafrost has developed to a depth less than 30 feet. This thin permafrost in recently deposited alluvium suggests that climatic conditions are now or have been recently favorable for the formation and preservation of permafrost in this part of the valley, despite the fact that permafrost in older alluvium is being degraded following the clearing of the natural vegetation.

Shallow borings in the narrow flood plain bordering Clear Creek, on Fort Wainwright, show that permafrost is generally absent to depths as great as 60 feet in places along the stream. Permafrost is apparently absent on the slip-off side of the large southwesterly bend of the creek at the southern edge of the area, but gradually thickens away from the newly deposited alluvium, just as it does in similar bends of the Chena River.

The lowest and youngest of the Chena River terraces border the flood plain, and form the cutbanks of the river (Qty, fig. 12). The low terraces at Fairbanks (fig. 12, $A-A^{\prime}$ and $B-B^{\prime}$ ) are underlain by much unfrozen alluvium containing isolated bodies of frozen ground, the base of which is as deep as 80 feet. Across the Chena River from Bentley's Island frozen terrace alluvium reportedly extends to a depth of 104 feet. Between the Chena River and Clear Creek on Fort Wainwright the frozen allu- vium reaches a depth of as much as 85 feet, but fewer holes were drilled here than at Fairbanks. In general, the frozen ground adjacent to the slip-off slopes is thin, but it is relatively thick along past and present cutbanks and at sites away from the river and lakes. Some of the abandoned channel scrolls are underlain by permafrost, but those that mark the last position of the river before cutoff of the meander are generally underlain by unfrozen alluvium (fig. 12, $A-A^{\prime}$ ).

A slightly higher and older group of terraces (fig. 12) is remote from the river in the eastern part of Fairbanks, but borders the south bank of the Chena River from a point south of Bentley's Island eastward to the mouth of Clear Creek. Permafrost is apparently more continuous there than in the younger terrace alluvium and reaches maximum measured depths of about 200 feet in southern Fairbanks (fig. 12, $B-B^{\prime}$ ) and 153 feet in western Fort Wainwright. In Fairbanks, where numerous water wells penetrate the frozen alluvium, the base of frozen ground becomes progressively deeper southward.

Beneath the oldest of the low terraces at Fairbanks frozen ground is nearly continuous and extends to depths as great as 242 feet. The terrace extends eastward into Fort Wainwright, but the thickness of frozen alluvium there is unknown. An eastward extension of the terrace beyond Fort Wainright to mile 11 on the Richardson Highway, beyond the area shown in figures 12 and 14, is underlain by frozen alluvium to a depth greater than 265 feet (Williams and others, 1959).

Alluvial deposits similar to those in the Fairbanks-Fort Wainwright area lie beneath suburban areas to the north and west of Fairbanks and to the east and southeast of Fort Wainwright. Records of 229 wells in the following areas were collected in 1947-54 (Cederstrom and Péwé, 1961; Cederstrom, 1963): Graehl, Hamilton Acres, Lemeta, College, settlements on Garden Island and along Badger Road, International Airport Way, Steese Highway, and Richardson Highway (fig. 12). The records include only a few wells drilled during the suburban expansion that began in 1950. Many wells are shallow and obtain water from unfrozen alluvium or from unfrozen alluvium above the permafrost table. About 95 wells obtain water from unfrozen alluvium beneath the permafrost. The wells are too widely scattered to delineate the configuration of permafrost, but the information available seems consistent with the general principles of local zonation of permafrost at Fairbanks and Fort 
Wainwright. Generally, wells in the flood plain did not reach frozen ground or penetrated only 20 or 30 feet of frozen alluvium near the surface. About half the wells on the low terraces penetrated 20 to 200 feet of frozen alluvium; the rest were drilled in unfrozen ground (table 2). Depth to the base of frozen ground ranges from 30 to 80 feet, comparable to that of similar terraces at Fairbanks and Fort Wainwright.

The progressive increase in maximum thickness of permafrost and in its areal continuity from the flood plain to successively older low terraces suggests that permafrost thickness and continuity are partly a function of the time elapsed since removal of the warming influence of the river that deposited the alluvium. It does not follow, however, that permafrost thickness would increase indefinitely if there were even higher and older terraces than the oldest one south of Fairbanks and Fort Wainwright. Undoubtedly climatic and other factors affecting ground-surface temperature and the regional geothermal gradient impose conditions that limit the maximum depth of permafrost. The maximum depth of permafrost in alluvium of the Tanana River valley is greater than 265 feet, and that in the creek-valley alluvium of the upland to the north is greater than 360 feet.

Forest fires, timber cutting, clearing the land for agriculture, and erection of buildings in the Fairbanks area since founding of the city in 1902 have locally raised the mean annual ground-surface temperature and have increased the amplitude of seasonal ground-temperature changes. In turn, the depth of the active layer has been increased and permafrost has been degraded. In some of the older cleared areas, the permafrost table has receded from an initial position near the surface to depths as great as 35 feet. The depth to which the thermal disturbance due to removal of vegetation has extended into the permafrost has not been measured. The permafrost will probably continue to thaw at its upper, marginal, and even its lower boundaries, whereas it will undergo little change or may be aggrading where the land retains its natural vegetation.

Layered permafrost is reported in several wells in the Fairbanks area (fig. 13). It may be accounted for by several hypotheses: (1) Lenses and beds of frozen sand and gravel that are undersaturated with ice have been observed in shafts or have been indicated by loss of drilling water. Under certain conditions these undersaturated, yet frozen, deposits may respond to the drill in the same way as unfrozen sediments and may be logged as unfrozen. (2) Drilling the irregular edge of a mass of frozen ground may produce a record of alternating frozen and unfrozen alluvium (Cederstrom, 1963). (3) Alternations of the mean annual ground-surface temperature about the freezing point may produce layered permafrost (Jenness, 1949; Terzaghi, 1952). Local disturbance of the vegetative cover, or especially rapid meandering of the river that last moved across the land, could account for layered permafrost. For example, if the warming effect of the river failed to thaw pre-existing permafrost completely, a deep remnant of the permafrost would be overlain by unfrozen ground. After migration of the river elsewhere, permafrost formed near the surface in the newly deposited alluvium would be separated from the old layer of permafrost by a layer of unfrozen alluvium. (4) During aggradation of permafrost, ground water becoming slightly more mineralized by fractionation and moving through permeable beds maintains thawed layers in the permafrost (Waller, 1961a; oral commun., 1962; written commun., December 1964). This hypothesis should be considered the least likely one because the unfrozen zone in the layered permafrost is not always the most permeable one and because slowmoving ground water flowing through frozen permeable beds may freeze itself (Theis, 1944, p. 6). Solution of the problems of layered permafrost still awaits application of geothermal techniques.

In the Fairbanks area, ground water occurs in permeable sand and gravel of the flood plain and low terraces below, within, and above the permafrost, where the permafrost table is lower than the water table (Cederstrom, 1952, 1963; Péwé in Hopkins and others, 1955). Ground water in wells drilled through frozen alluvium rises to a static level that is approximately that of nearby watertable wells drilled in unfrozen alluvium. The westward slope of the water table and potentiometric surface, normally 5-15 feet below land surface, is approximately the same as that of the land surface. Storage of water is enormous in the unfrozen alluvium beneath permafrost and in unfrozen zones that perforate the permafrost (Cederstrom, 1952; $1961 b ; 1963$, p. 37-38). Any withdrawal from storage by pumping can be replaced readily by infiltration from surface streams through unfrozen zones and by lateral movement of water within the unfrozen alluvium to the pumping well. Cederstrom $(1963$, p. 44) attributed uneven drawdown curves in pumping tests in the alluvium to the lenticularity of beds. However, these curves may also have been 
TABLE 2.-Depth of frozen alluvium in Fairbanks area wells

\begin{tabular}{|c|c|c|c|c|c|c|}
\hline $\begin{array}{l}\text { Suburb } \\
(\text { fig. } 12)\end{array}$ & $\begin{array}{l}\text { Total } \\
\text { wells }\end{array}$ & $\begin{array}{l}\text { Wells no } \\
\text { frozen } \\
\text { alluvium } \\
\text { logged }\end{array}$ & $\begin{array}{l}\text { Wells in } \\
\text { frozen } \\
\text { alluvium }\end{array}$ & $\begin{array}{l}\text { Wells } \\
\text { drilled } \\
\text { through } \\
\text { base of } \\
\text { frozen } \\
\text { alluvium }\end{array}$ & $\begin{array}{l}\text { Range of } \\
\text { depths } \\
\text { to base } \\
\text { of frozen } \\
\text { alluvium } \\
\text { (feet) }\end{array}$ & $\begin{array}{l}\text { Maximum } \\
\text { depth to } \\
\text { base of } \\
\text { permafrost } \\
\text { (feet) }\end{array}$ \\
\hline \multicolumn{7}{|l|}{ Aurora Subdivision, } \\
\hline Garden Island & 2 & 0 & 2 & 2 & $40-57$ & 57 \\
\hline Badger Road-......... & 11 & 6 & 5 & 5 & $38-123$ & 123 \\
\hline College-_- & 38 & 13 & 25 & 15 & $\begin{array}{l}32-39 \\
80-101 \\
110-175+\end{array}$ & $175+$ \\
\hline \multicolumn{7}{|l|}{$\begin{array}{l}\text { Garden Island } \\
\quad \text { (Fairbanks-Slater- }\end{array}$} \\
\hline ville) & 45 & 30 & 15 & 14 & $26-70$ & 180 \\
\hline Graehl-n..-. & 37 & 21 & 16 & 11 & $40-73$ & 73 \\
\hline $\begin{array}{l}\text { Hamilton Acres } \\
\text { International Airport }\end{array}$ & 20 & 6 & 14 & 14 & $32-77$ & 77 \\
\hline Road-_. & 11 & 2 & 9 & 6 & $\begin{array}{l}41-55 \\
120-172+\end{array}$ & $172+$ \\
\hline Lameta Subdivision----- & 18 & 4 & 14 & 12 & $\begin{array}{l}23-79 \\
100-154+\end{array}$ & $154+$ \\
\hline South Fairbanks and & & & & & & \\
\hline Richardson Highway--- & 27 & 16 & 11 & 7 & $32-87$ & $265+$ \\
\hline Steese Highway-_-_-_- & 20 & 1 & 19 & 9 & $45-98$ & 114 \\
\hline Total---n-- - - - & 229 & 99 & 130 & 95 & & \\
\hline
\end{tabular}


related to impermeable boundaries imposed by permafrost or by other phenomena not considered by the methods used for analyzing the data. Tests at Fort Wainwright showed that transmissivity of the alluvium is several hundred thousand gallons per day per foot (Cederstrom, 1963, p. 45).

\section{NENANA}

The village of Nenana lies along the south bank of the Tanana River upstream from its confluence with the Nenana River (fig. 5). Wells less than 60 feet deep supply water to the village and to the airport (Cederstrom, 1952). The airport well was drilled through frozen alluvium from a depth of 15 to 40 feet. The frozen alluvium is apparently thin and sporadically distributed (Kachadoorian, 1960). Foundation borings for the Fairbanks-Anchorage highway bridge across the Tanana River at Nenana showed that frozen ground is absent in alluvium beneath the river to depths as great as 178 feet (Alaska Department of Highways, unpub. data).

\section{MINTO}

Minto is on a low terrace north of the Tanana River (fig. 5). An early attempt to obtain a ground-water supply was abandoned when the 60foot test well failed to reach the lower limit of frozen alluvium (Cederstrom, 1952, p. 26). Three wells drilled in 1961 and 1962 produce water from sand and fine gravel beneath 22 to 52 feet of frozen alluvium. The water is confined beneath the base of the frozen layer and rises to within 12 feet of the land surface.

\section{MANLEY HOT SPRINGS}

Two wells, 40 and 75 feet deep, are reported (Cederstrom, 1952, p. 26) at Manley Hot Springs, on the Tanana River flood plain. The deeper well produces hard water from gravel and sand beneath a frozen zone which is reported from 42 to 54 feet below land surface. The hot springs are across a channel of the river from the village. The distribution of permafrost in the alluvium probably is affected more by proximity of the river channel than by the heat from the springs. The ground near the thermal springs is undoubtedly unfrozen.

\section{KUSKOKWIM RIVER VALLEY}

Water from wells drilled in flood-plain and lowterrace alluvium of the Kuskokwim River valley supplies the villages of McGrath, Crooked Creek, Aniak, Akiachak, Akiak, and part of Bethel (fig. 7). In the wells in which observations of water level have been made, fluctuations were noted that corresponded with change in stage of the nearby river.

McGrath, located on recently deposited alluvium along the slip-off slope of a meander of the Kuskokwim River, is supplied by about 25 wells that obtain water from unfrozen sand and gravel. The wells nearest the river, on the youngest alluvial deposits, were drilled in unfrozen alluvium, but those on slightly higher, older alluvial surfaces away from the river, penetrated as much as 52 feet of frozen alluvium before reaching water-bearing unfrozen sand and gravel (Cederstrom, 1952, p. 29; Fernald in Hopkins and others, 1955, p. 131; Fernald, 1959, p. 204). Construction activities and clearing of the natural vegetation in some parts of the village have caused degradation of the thin permafrost.

Alluvium is unfrozen in four wells, 30-105 feet deep, at Aniak and in three wells, 18-30 feet deep, at Akiak. A 17-foot well at Crooked Creek and two wells, 38 and 43 feet deep, at Akiachak obtain water from alluvium beneath permafrost.

In the Bethel area, wells on the flood plain and low terraces produce water from shallow alluvium in permafrost-free areas close to the river and the nearby large flood-plain lakes and from deep sand beneath the permafrost (fig. 15) (Waller, 1957a). The flood plain and low terraces are bounded on the west by a terrace escarpment that separates them from an older part of the Yukon-Kuskokwim delta, a part of the coastal lowlands. Frozen ground in wells is less than 20 feet thick in flood-plain and low-terrace alluvium in the old airport area, on an island in the river, and near Hangar Lake (fig. 15). But in the village, between the creek and the terrace escarpment, the deposits are frozen to depths as great as 377 feet. The thin permafrost in the old airport area and near Hangar Lake has been formed in alluvium deposited during migration of the river across those localities. The thick permafrost at the village may be accounted for by postulating that the river has been in its present position too short a time to thaw the permafrost at depth. Partial degradation of permafrost by a rapidly migrating river is suggested by the layering of the frozen ground in the 149-foot well at Bethel (fig. 15). In that well, the upper layer of frozen alluvium extending from 4 to 52 feet below land surface is separated by unfrozen ground from the lower frozen layer that extends from 148 feet to an unknown depth. However, as shown earlier, little is known about the origin of layered permafrost, and as thermal data are lacking, its origin remains speculative. 


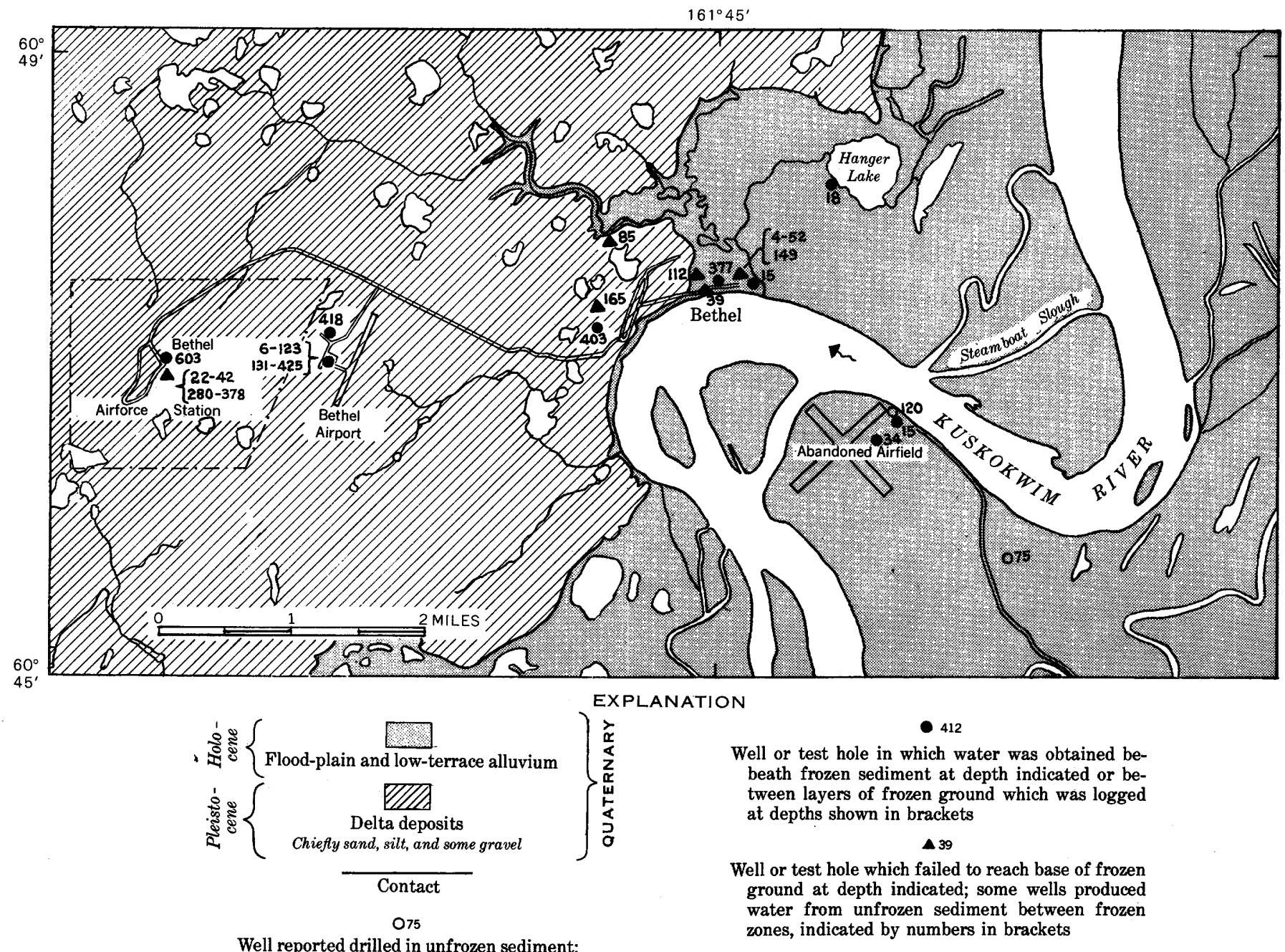

ALL DEPTHS. IN FEET BELOW LAND SURFACE

FIgURE 15.-Well-locations and geology of the Bethel area.

COPPER RIVER LOWLAND

The Copper River and its major tributaries have formed narrow valleys incised into glacial and glaciolacustrine deposits. The valleys contain flood plains and low terraces (fig. 8); the alluvium is thin, and some wells have been drilled into the underlying glaciolacustrine clay, silt, and sand and glacial deposits. Fresh and saline or brackish water in permeable beds in the glacial and glaciolacustrine deposits seeps locally into the alluvium from the bluffs bordering the valley or leaks upward into the overlying alluvium.

Wells, generally less than 40 feet deep, produce water from unfrozen flood-plain and low-terrace alluvium along the Copper River near the mouths of its larger tributaries (fig. 8) (Nichols, 1956; Waller and Selkregg, 1962; Waller and Tolen, 1962b). Potable water is produced at shallow depths from alluvium at various places in the lowland. The locations and approximate well depths are as follows: Slana, 20 feet; Christochina, 30 feet; Tolsona Creek 15 miles west of Glennallen, 20 feet; and Gulkana, 20 feet. Wells 14-61 feet deep at Copper Center produce slightly saline water or hard fresh water. Near the mouth of Tazlina River some wells 15-65 feet deep in terrace alluvium and subjacent sediments yield brackish or saline water; others produce hard water. At Gulkana an 89-foot well, presumably drilled through the alluvium, produced saline water from underlying glacial and glaciolacustrine deposits. Permafrost was not reported in any of the wells cited, but has been reported in a 22-foot well on a terrace of Tonsina River near Richardson Highway (Waller and Tolen, 1962b).

Alluvium beneath a high terrace that extends 8 miles west of Glennallen along the north bank of the Tazlina River (fig. 16) consists of coarse gravel 10-20 feet thick. The gravel lies upon glaciolacus- 


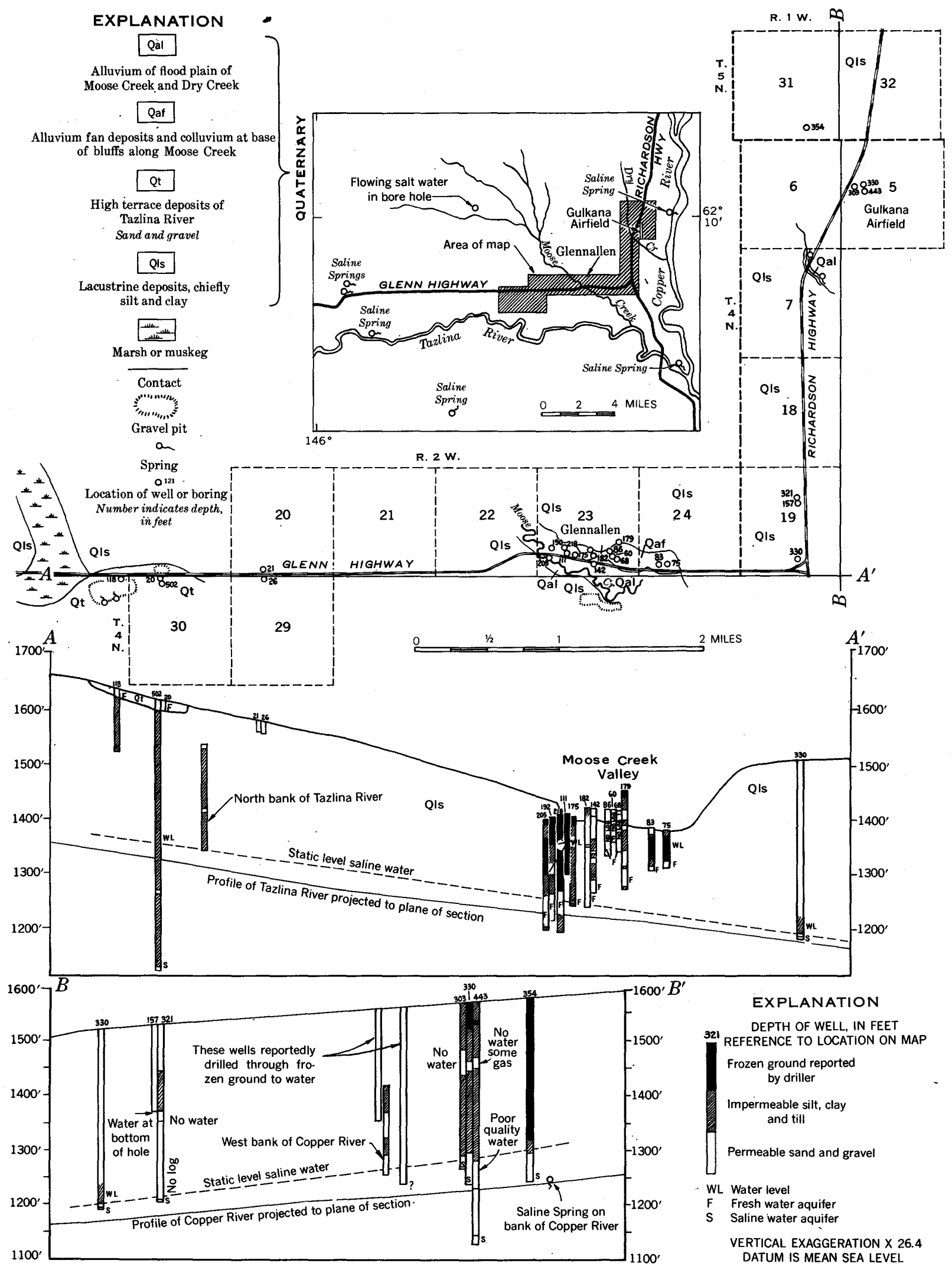

FIGURE 16.-Geology of the Glennallen-Gulkana airfield area. 
trine silt or clay. Shallow wells in unfrozen gravel yield water to domestic wells and to some publicsupply wells. The water apparently enters the alluvium from muskegs in summer (Nichols, 1956) and moves eastward through the terrace gravel. In winter, when drainage of surface water from the muskegs ceases, the upper part of the thin alluvium freezes, and the wells either fail to produce or yield only scant supplies (Nichols, 1956). Similar highterrace deposits south of the Tazlina River and along the Klutina River and some of the eastern tributaries of the Copper River have not been tested for their ground-water potential.

Permafrost, which is of rather small extent in the alluvium of the Copper River and its tributaries (Nichols, 1956), is relatively unimportant in relation to development of ground water, compared to similar areas farther north. Instead, the major problems are: (1) Locating a thick section of alluvium and (2) avoiding that alluvium into which hard and saline waters have seeped from glacial and glaciolacustrine deposits beneath the alluvium or from bluffs along the valley margins.

COOK INLET AND BRISTOL BAY LOWLANDS

No permafrost is known in alluvial deposits in the major valleys of the Cook Inlet and Bristol Bay lowlands of southern Alaska (figs. 7 and 8). Ground water is probably available in shallow wells in these deposits.

ALLUVIAL FANS OF MAJOR VALLEYS

Large alluvial fans border many of the major mountain ranges. Especially extensive areas of alluvial fans (shown in fig. 2) border the northern Alaska Range in the Tanana and Kuskokwim River valleys, the southern Brooks Range in the Yukon River valley, and some of the mountain ranges of Seward Peninsula. Many other fans are too small to be shown at the scale of the map. The alluvial fans are partly glacial-outwash deposits. In some major valleys an outwash fan borders Pleistocene glacial moraines deposited at the edge of the major valley by ice from one or more tributary valleys. In other tributary valleys, valley-train terraces can be traced from the moraine within the mountains to an alluvial fan formed by the tributary at the margin of the major valley. The fans consist of coarse gravel and sand near the apex and finer gravel, sand, and silt near the toe. Within the limits of Pleistocene glaciation (fig. 2) the deposits are interbedded with till.

Little is known about the distribution of permafrost in alluvial-fan deposits. Although no subsur- face data are available, permafrost is probably continuous and thick in the Arctic drainage basin. Frozen ground is sporadic and rather thin in the areas of the discontinuous-permafrost zone for which subsurface records are available.

The alluvial-fan deposits are highly permeable and porous, especially near their apexes, and they are excellent aquifers along the rivers. Data available for alluvial-fan deposits show that the base of frozen alluvium generally lies above the water table or, in areas within the limits of Pleistocene glaciation, above the potentiometric surface of water that is confined by relatively impermeable till. At such places permafrost seems to have little effect on the occurrence of ground water other than restricting local infiltration of snowmelt and precipitation from the surface. However, near the toes of the fans, where the water level is close to the land surface, ground water may be confined beneath the base of the frozen alluvium.

\section{NORTHERN ALASKa}

The alluvial-fan deposits that form terraces bordering the rivers of the Brooks Range and the Arctic Foothills in the continuous-permafrost zone have not been tested for water by drilling. However, the thick, areally continuous permafrost elsewhere in this region indicates that water supplies in the alluvial deposits may be obtained only where lakes and large streams on the fans have formed an unfrozen zone that is deeper than the depth of winter frost penetration.

Springs along the shore of Lake Tulugak near Anaktuvuk Pass of the central Brooks Range (fig. 4) issue from the toe of an alluvial fan (Spetzman, 1959 , p. 37, fig. 8). The source of water discharged from these springs may prove to be fault zones within or bounding the limestone of the Lisburne Group, which is exposed in the hills near the fan apex. Water in similar springs from limestone in the eastern Brooks Range is well above the freezing point. Water emerging from bedrock at Lake Tulugak may keep alluvial-fan deposits unfrozen as it percolates through the alluvium to emerge at the toe of the fan.

On Seward Peninsula, near the boundary between discontinuous and continuous permafrost, the streams on some alluvial fans reportedly lose much of their summer flow by percolation into coarse fan gravel, and the water emerges again at springs at the toe of the fan (Hopkins and others, 1955, p. 121). 
YUKON RIVER VALLEY

Alluvial fans of the Sheenjek, Christian, Chandalar, and Yukon Rivers occupy much of the northern Yukon Flats (fig. 2). No wells have been drilled on the fans; however, some of the small streams crossing the fans of the Christian and Sheenjek Rivers disappear into the alluvium, suggesting that the fan may be locally permeable and unfrozen (Williams in Hopkins and others, 1955, p. 126).

\section{TANANA RIVER VALLEY}

Large alluvial fans occupy much of the southern Tanana River valley from the Canadian border westward to the Kantishna River (fig. 5). Many of the fans are formed by glacial outwash. Among the rivers crossing the fans, the Tok River, Moose River (tributary to Kantishna River), Dry Creek (Capps, 1911, 1912; Waring, 1917), and Gerstle River (H. R. Schmoll, written commun., November 1964) are known to be influent and to recharge the ground water in the alluvium. Subsurface data are available from wells on the fan of Tok River at Tok and Tanacross, on the fan of Gerstle River, on the fan of Nenana River near Clear, and on outwash deposits fronting moraines east of Delta River near Fort Greely (Waller and Selkregg, 1962; Waller and Tolen, 1962a, b; Péwé and Holmes, 1964).

The large alluvial fan of Tok River extends northward from its apex in the Alaska Range to the south bank of the Tanana River between the Alaska Highway bridge and Tanacross (fig. 8). The Tok River flows perennially at the Glenn Highway bridge near the apex of the fan, but flows only in summer at the Alaska Highway bridge near the toe. In February 1950, the entire flow, estimated at 50 cfs, at the apex of the fan was seeping into the fan deposits because the river was dry at the toe of the fan at that time. Water is discharged from springs at the toe of the fan which forms the south bank of Tanana River.

Alluvial deposits of the Tok fan supply ground water to the settlements of Tok and Tanacross. The deposits are coarse to fine sandy gravel containing beds and lenses of silt and sand. The alluvium is more than 120 feet thick at Tok. Records of wells (fig. 17) show that the water table in all but one well is between 53 and 70 feet below land surface. Frozen ground was reported in four of 16 wells near Tok and in two of seven near Tanacross, but its maximum depth in these wells was only 35 feet. The thin, isolated masses of permafrost lying above the water table have no effect in confining the ground water or in limiting its movement.

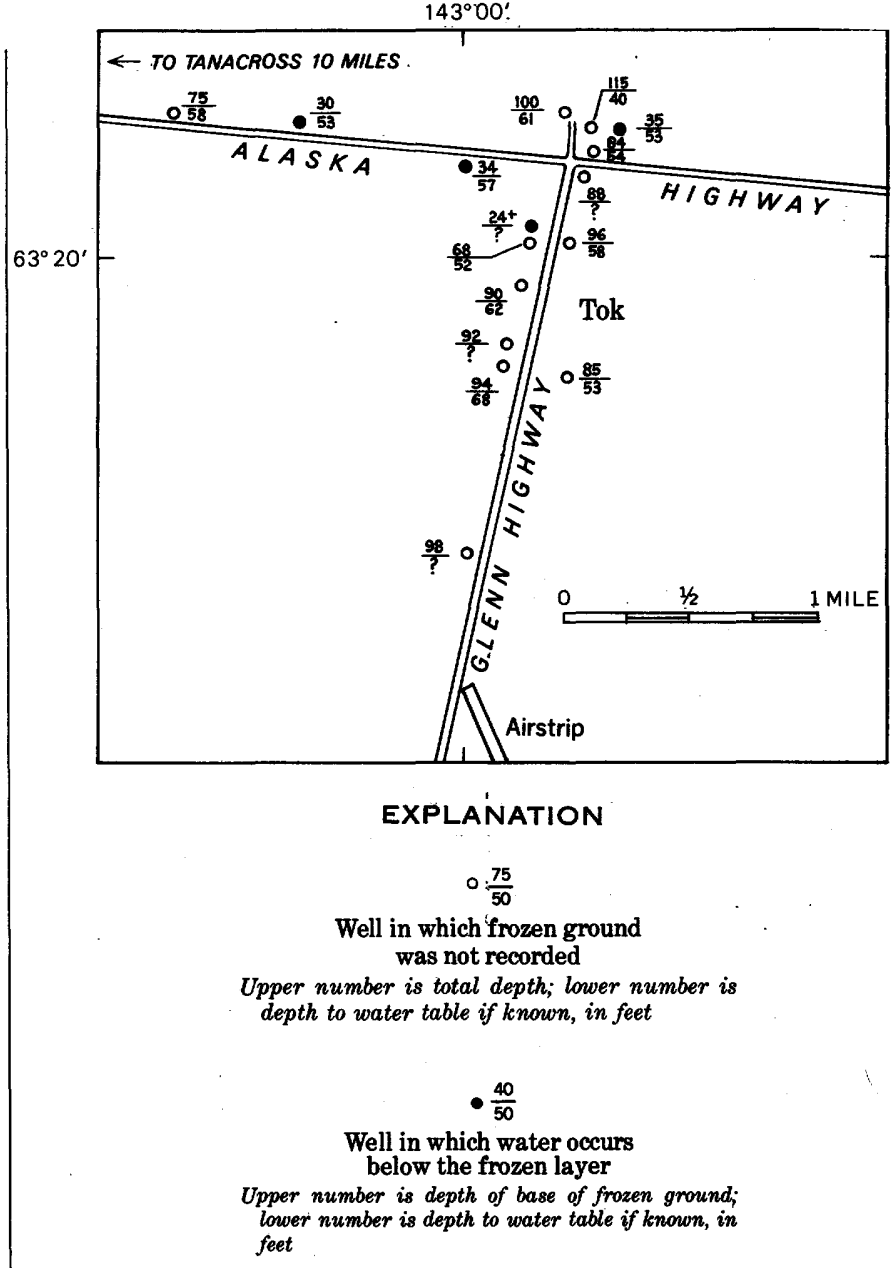

Figure 17.-Well-locations in the Tok area, Tanana River valley.

Steeply sloping fans formed by small creeks border the northern front of the Alaska Range in the Tanana River valley between Tanacross and Cathedral Rapids (fig. 2). Water was obtained from coarse fan gravel in two wells at Cathedral Bluffs. In one well, frozen ground was reported from 3 to 12 feet and from 30 to 33 feet below land surface; in the other well the base of frozen alluvium was penetrated at a depth of 17 feet. The water table in both wells was below the base of the frozen ground.

A well in the fan deposits along Gerstle River about 3 miles south of the Alaska Highway bridge (fig. 5) was drilled by U.S. Army Engineers. The upper 80 feet was in frozen fan gravel, and the base of frozen ground was at 122 feet in the underlying sand and till. Although a small amount of water was obtained in the till at the base of the frozen layer, it was inadequate to supply the demand, and the well was deepened to 549 feet. Water was obtained from sand and gravel at a 
depth between 468 and 472 feet, and rose to a static level that was 457 feet below land surface, or 355 feet below the base of the frozen ground.

Outwash fans border the Donnelly (Wisconsin) and Delta (Illinoian) moraines in the Fort Greely area (Péwé, 1953; Péwé and Holmes, 1964). Fort Greely lies on the outwash apron fronting the Donnelly moraine within the area covered by ice during the Delta Glaciation. The surficial Donnelly outwash, consisting of fine to coarse sandy gravel containing beds and lenses of sand and silt, is underlain by till of the Delta Glaciation, which, in turn, lies above an older gravel. At Fort Greely the Donnelly outwash is above the water table, but the gravel beneath the Delta till contains water that is confined by the relatively impermeable till. According to Waller, Feulner, and Tisdel (1962), water is apparently recharged by the Delta River southwest of Fort Greely into the alluvium beneath the till. The water moves northeastward, passes about 200 feet beneath the bed of Jarvis Creek at right angles to the direction of creek flow, and emerges as springs near Clearwater Lake (fig. 18). Here the toe of the Delta outwash fan forms a low gravel escarpment along the south side of the Tanana River flood plain.

Frozen ground at Fort Greely extends to a maximum recorded depth of 217 feet, but it is recorded in only one-third of the wells (Cederstrom, 1952, p. 27; Waller and Tolen, 1962a, b; Péwé and Holmes, 1964). The altitude of the recorded base of frozen ground (fig. 16) is plotted for comparison with the altitude of the potentiometric surface of ground water confined beneath the till. In all but one well the base of permafrost is above the potentiometric surface, and in that well till is the confining layer, not permafrost. At Fort Greely, therefore, the hydrology of the ground water is dependent on the stratigraphy of the Quaternary deposits, and is independent of permafrost.

Wells less than 65 feet deep along the Richardson Highway at Big Delta, near the confluence of Tanana and Delta Rivers (fig. 5), produce water from outwash of Donnelly age. The water table in these wells is $20-30$ feet below land surface. Few of the wells have been drilled in frozen ground.

At Donnelly flat, between the Richardson Highway and Jarvis Creek 12 miles south of Fort Greely, outwash of the Donnelly Glaciation (Péwe and Holmes, 1964) is underlain by till that lies above a lower gravel unit. Permafrost was logged in four of 15 borings and wells. The permafrost table in the four holes is $33-42$ feet below land sur- face and the maximum depth of the base of frozen ground is 51 feet. Ground water in the Donnelly outwash is perched on the permafirost table, but the major aquifer is the gravel beneath the till. Water in this aquifer is confined by the relatively impermeable till and its potentiometric surface is below the deepest frozen ground recorded. The frozen ground, as at Fort Greely, is thin and sporadic and has little effect on the ground-water hydrology.

Wells near Clear (fig. 5) on the Alaska Railroad have been drilled in unfrozen coarse gravel and sand near the apex of the alluvial fan of Nenana River. However, permafrost has also been reported in alluvial deposits of this fan along the route of the Fairbanks-Anchorage highway between Nenana and Rex (fig. 5). The water table in wells at Clear Air Force station is $40-70$ feet below land surface, but is 15-20 feet below land surface in the shallow wells and pits closer to the railroad (Kachadoorian, 1960). The water is apparently recharged by the Nenana River into the fan gravel, but no measurements of loss of flow of the river have been made yet.

\section{KUSKOKWIM RIVER VALLEY}

Broad outwash fans border the glacial moraines that extend into the Kuskokwim River valley along the front of the Alaska Range. The only well in this large region was drilled at Farewell Landing within the belt of the moraines, but near the deeply entrenched valley of South Fork Kuskokwim River. The depth to the base of frozen ground in the well is reported as either 12 or 125 feet (Cederstrom, 1952, p. 29; Fernald in Hopkins and others, 1955, p. 131 ; Fernald, 1959 , p. 204). Water is produced from an aquifer beneath the glacial drift that lies beneath the surficial outwash deposits. Water level was reported 338 feet below land surface. At this location, at least, permafrost seems to have little relation to the hydrology.

\section{ALLUVIUM OF MOUNTAIN AND UPLAND VALLEYS IN DISCONTINUOUS-PERMAFROST ZONE}

Ground water in the alluvium of smaller valleys in the mountains and uplands is stored in, and moves through, unfrozen, permeable sand and gravel beneath streambeds and locally beneath flood plains and terraces. Thin, unfrozen alluvial aquifers in many valleys are localized beneath rivers and lakes, but in other valleys, where the alluvium is thick, alluvial aquifers may exist beneath permafrost. 


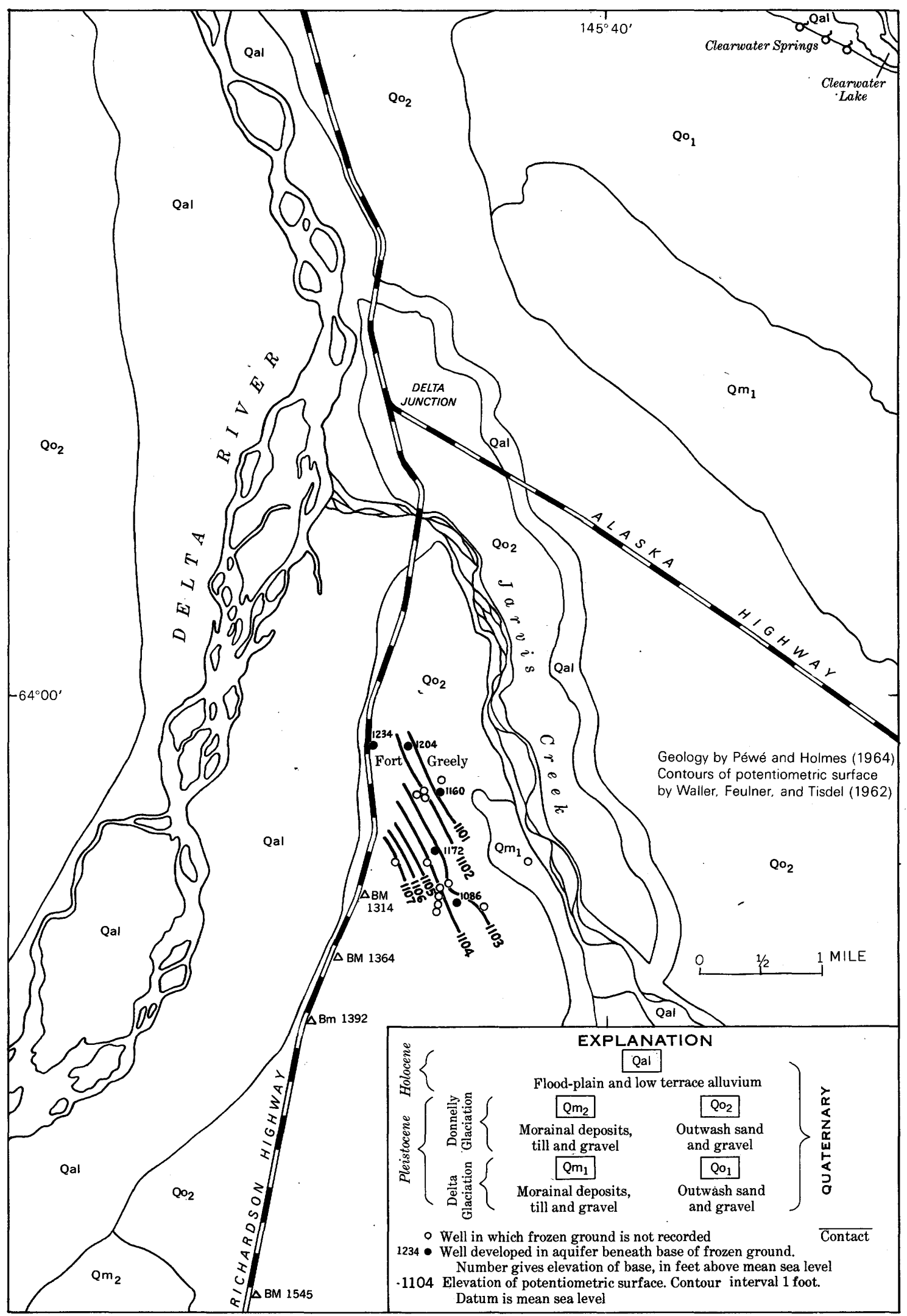

FIGURE 18.-Geology, slope of the potentiometric surface, and location of selected wells in the Fort Greely area. 
Examples of the occurrence of ground water and distribution of permafrost, given below, have been selected to illustrate the variety of permafrost conditions in alluvium. They also show that many small valleys in the mountains and uplands contain productive alluvial aquifers despite the widespread occurrence of permafrost.

\section{UPLANDS NORTH OF YUKON RIVER}

Prospecting for placer gold has been carried out in the Gold Hill district between Tanana and Birches and in the Marshall district (fig. 4) near $62^{\circ}$ N., $162^{\circ}$ W., on the lower Yukon River. In the Gold Hill district, some shafts were dug through 10-12 feet of unfrozen creekbed and terrace alluvium to bedrock on the upper tributaries of Illinois and Grant Creeks (Eakin, 1912; Martin, 1919), but many other shafts were dug in frozen ground (Maddren, 1909).

Alluvial deposits in the headwater reaches of creeks draining the uplands east of Marshall (fig. 7) are thin, coarse-grained, and generally unfrozen, but the thicker alluvium in the middle and lower segments of these valleys is frozen and consists of silt that lies above a thin basal gravel unit just above bedrock (Brooks, 1915). Shafts dug in unfrozen alluvium were flooded by ground water.

\section{Southern Seward Peninsula}

Alluvial sand and gravel in upland valleys of southern Seward Peninsula are interbedded locally with glacial deposits. According to Hopkins (in Hopkins and others, 1955, p. 123), permafrost is generally 100-200 feet thick, but unfrozen zones are more extensive along perennial streams and are found beneath streams smaller than those in the northern Seward Peninsula. Unfrozen zones lie beneath most of the flood plain, and are common in alluvial fans.

Ground water is available from the unfrozen alluvium of flood plains. Springs emerge at the lower edges of the alluvial fans and water in these alluvial-fan deposits is more abundant in summer than in winter (Hopkins, in Hopkins and others, 1955, p. 124).

\section{YUKON-TANANA UPLAND}

The upland between the Yukon and Tanana Rivers (fig. 5) is an area of even-topped ridges and narrow valleys broken by higher, more rugged mountains and valleys of the principal streams. The alluvium of the principal valleys is generally thick in the middle to lower reaches. Immediately north of the Tanana River the lower hills are mantled with loess. Streams have washed the loess and silt derived from weathered schist to valley bottoms where the silt forms an important component of the alluvium. The distribution of permafrost and its relation to ground-water occurrence is similar to that of the major valleys. Placer mining in the Circle, Eagle-Fortymile, Fairbanks, Rampart, and Tofty-Eureka-Hot Springs districts, discussed below, provides subsurface data on permafrost and ground water in the alluvium of the smaller valleys in the Yukon-Tanana Upland.

CIRCLE MINING DISTRICT

Unfrozen water-bearing sandy gravel in the flood-plain alluvium, particularly beneath creekbeds, is common to several small valleys of the Circle mining district (fig. $5,65^{\circ} \mathrm{N}$., $145^{\circ}$ W.). Among them are: Crooked Creek, where wells near Central penetrate as much as 45 feet of unfrozen gravel; Harrison Creek (Brooks, 1909; Prindle, 1913a); and Mammoth Creek, where shafts have been dug through 10-16 feet of locally unfrozen alluvium to bedrock (Brooks, 1907, 1915; Ellsworth and Parker, 1911). The thickness of the alluvium on Deadwood Creek increases from a few feet at its headwaters to about 100 feet in its lower reaches in the Birch Creek flats. Much of the gravel along the creek is unfrozen. At one mine near the head of the creek, winter frost did not reach bedrock until February, and the underflow continued to that time (Brooks, $1907,1909)$. Only part of the alluvium along Mastodon Creek is frozen (Brooks, 1907; Ellsworth and Davenport, 1913). Gravel on Eagle Creek, mantled with 5-15 feet of silt, remained unfrozen and water bearing throughout at least one winter (Brooks, 1907). Many of the shafts in the Circle district penetrate 15-25 feet of frozen alluvium before entering unfrozen, water-bearing gravel above the bedrock (Purington, 1905).

\section{EAGLE-FORTYMILE MINING DISTRICT}

The Eagle-Fortymile district (fig. 5, approx $65^{\circ}$ N., $141^{\circ}$ W.) consists of several small mining camps along the Fortymile River and its tributaries and along Poker Creek near the Canadian boundary. Many mine shafts dug through 15-25 feet of frozen alluvium have been flooded by water in unfrozen gravel just above bedrock (Purington, 1905). Other shafts and wells have been dug through 35 to more than 360 feet of frozen ground. Icings, indicating underflow through unfrozen creekbed alluvium, form on many of the creeks, but much of the gold- 
bearing alluvium bordering the smaller streams is frozen. The Fortymile River, the largest one in the area, has much unfrozen alluvium (Prindle, 1908a). On upper Chicken Creek, alluvial deposits 40-50 feet thick are partly unfrozen, as indicated by reports that the deposits were too wet for prospecting by shafts (Mertie, 1930). A 360-foot test well on Chicken Creek near the Taylor Highway was drilled through creek alluvium and sedimentary rocks of Tertiary age without reaching the base of frozen ground.

\section{RAMPART MINING DISTRICT}

The Rampart mining district (fig. $5,65^{\circ} 30^{\prime} \mathrm{N}$., $150^{\circ} \mathrm{W}$.) occupies the narrow tributary and main valleys of Minook Creek, a tributary of the Yukon River. The alluvial deposits of these valleys are generally about 20 feet thick, but are known to be as much as 100 feet thick locally (Prindle and Hess, $1906)$. In the larger valleys, the alluvial deposits, which are chiefly sand and gravel, are interbedded with and, along valley margins, overlapped by silt of coalescent alluvial fans formed by smaller streams. In general, the silt and gravel deposits bordering the stream are frozen, but local channels in these gravel deposits are unfrozen (Prindle and Hess, 1906).

Ground water occurs in unfrozen, coarse alluvium beneath the larger streams and in unfrozen channels beneath the valley bottom bordering some of the streams. Water circulates freely through these unfrozen zones during all seasons. Eakin (1913c) stated that the unfrozen zones are most numerous where the gravel is especially permeable. Icings on Minook Creek indicate the persistence of streamflow or underflow throughout much of the winter (Mertie, 1934). Both the surficial silt and underlying gravel on upper Hunter Creek are frozen; similar deposits, as much as 40 feet thick, in the Little Minook Creek valley are generally also frozen (Mertie, 1934), but reportedly contain local zones of water-bearing gravel (Ellsworth, 1910). Unfrozen water-bearing gravel is found locally beneath frozen silt bordering Little Minook Junior Creek, but the alluvium along Hoosier Creek and in the bed of Slate Creek generally is frozen (Mertie, 1934). However, ground water in local unfrozen zones in the alluvium along Hoosier and Ruby Creeks has hindered placer-mining operations. Underground mine workings on some creeks were flooded when abandoned water-filled shafts were intercepted by drifting. The water in those shafts had become partially frozen from the sides inward and from the top downward, but the water in the center had remained unfrozen for several years (Prindle and Hess, 1906).

\section{TOFTY-EUREKA-HOT SPRINGS MINING DISTRICT}

The Tofty-Eureka-Hot Springs district (fig. 5, $65^{\circ} \mathrm{N}$., $151^{\circ} 30^{\prime} \mathrm{W}$.) has been mined and prospected for placer gold and tin, but most of the older subsurface records are no longer available (Ellsworth, 1910; Eakin, 1913c, 1915b; Mertie, 1934; Thomas, 1957). Alluvial deposits, 50-170 feet thick, consist of thick surficial silt that covers basal gravel ranging in thickness from a few feet to 35 feet. In the upper parts of upland valleys, gravel is unfrozen to bedrock, but downstream the gravel is covered by a thick mantle of silt and depths to bedrock increase on the lower reaches of these streams. Almost all records of boreholes and shafts show that the frozen conditions extend into bedrock (Thomas, 1957). Maximum thickness of frozen ground is more than 130 feet. Only a few records are available of flooding of underground workings by ground water beneath the frozen layer; for example, a 50- to 60-foot shaft a quarter of a mile west of Tofty (fig. 2) was flooded by ground water (Eakin, 1915b). The only record of a deep water well is that of one drilled 200 feet in search of artesian water, apparently without success, because the attempt was suspended for lack of casing (Rickard, 1909).

Although the available information suggests that most of the alluvium is frozen, water may be available in unfrozen alluvium beneath upper courses of the creeks and in deep alluvium beneath the larger creeks, such as Omega Creek and Hutlinana Creek (Prindle and Hess, 1906), where unfrozen zones are common.

\section{FAIRBANKS MINING DISTRICT}

The upland north of the Chena and Tanana Rivers in the Fairbanks mining district ranges in altitude from about 800 to 3,000 feet above sea level (fig. 12). Hilltops and lower slopes near the Tanana River are largely mantled by the Fairbanks Loess, and the lower slopes of higher hills farther north are locally covered by loess (Péwé, 1948b, 1958a; Williams, 1959; Williams and others, 1959; Péwé and Rivard, 1961). In their headwater reaches, most small streams flow on beds of gravelly alluvium that is generally less than 50 feet thick. Downstream, where the gradient of the stream is lower, the gravelly alluvium is buried by, or intercalated with, thick deposits of silt in places contain- 
ing organic material. There, alluvium ranges from a few feet thick near the margins to a recorded maximum of 360 feet in the center. The streams flow in meandering courses across narrow flood plains composed of silt, sand, and, locally, fine gravel. The flood plains are bordered by coalescent alluvial fans of silt deposited by tributaries along the valley margins. In most valleys the thickness of the alluvium increases downstream, but in a few valleys, where stream capture or faulting has taken place, broad valley segments filled by thick alluvium are terminated downstream by narrow segments underlain by thin alluvium. The complex stratigraphy of the alluvial fills reflects a long history of erosion, deposition, and stream capture (Mertie, 1937; Tuck, 1940; Taber, 1943; Péwé, 1952, 1953, 1958a, b).

The distribution of frozen creek-valley alluvium is known from records of early-day prospect and mine shafts, from records of later prospect drilling, and from water wells. These records show that permafrost occurs from near the surface to depths of at least 360 feet in the middle and lower parts of the creek valleys (fig. 14), but that its thickness varies from place to place. Although the side of the valley having the greater insolation would be expected to have the thinnest permafrost (Muller, 1947), this relationship is not demonstrated consistently by the data. Generally the thickness of permafrost increases downvalley, but exceptions are common.

Ground water is abundant in unfrozen coarse sand and gravel. However, the overlying silt is relatively impermeable and does not yield significant quantities of water. The occurrence of water in the permeable alluvium depends on whether permafrost extends to the underlying bedrock. Where permafrost extends into bedrock, as in the Dome Creek valley (figs. 14 and 19), no water is obtained from the alluvium. But where alluvium lies below the base of permafrost, as in the Happy Creek area (figs. 14 and 19), the alluvium will yield water. Water is recharged to the alluvial aquifers and to subjacent bedrock aquifers through unfrozen zones on the upper slopes and on summits of the hills and through unfrozen alluvium beneath the upper reaches of the creeks (Cederstrom and Tibbitts, 1961 ; Cederstrom, 1963, p. 77, fig. 6).

From records of about 75 wells in the Isabella Creek valley, between the Steese Highway, McGrath Road, and Farmers Loop Road north of Fairbanks (Cederstrom and Tibbitts, 1961; Cederstrom, 1963), form lines have been sketched to show the approximate shape of the bedrock surface and the poten- tiometric surface (fig. 20). The data show that most of the bedrock valley is filled with silt, but that locally the silt is separated from the bedrock surface by gravel deposited in old stream courses. The maximum known thickness of the gravel is more than 72 feet, but few wells have been drilled in the central part of the valley where the thickest gravel is to be expected, and none have been drilled through the gravel. The gravel probably thickens downvalley to merge with lower units of the alluvial sand and gravel fill of the Tanana River valley, and the silt merges downvalley into alluvial-fan deposits of Isabella Creek that overlie and interfinger with sand and gravel in the Tanana River valley.

Ground water in the coarse alluvium beneath the Isabella Creek valley is confined by the base of permafrost and by overlying beds of relatively impermeable silt. The form lines (fig. 20) show that confined ground water moves from the hills toward the Isabella Creek valley and southward to the Tanana River valley. Flowing artesian wells are common in the lower parts of the valley along Isabella Creek. Difficulties in capping a flowing well (fig. 20, well A) (Jaillite, 1947) were caused by thawing of ground ice in the frozen silt surrounding the casing. Thawing by flowing ground water enlarged the opening surrounding the casing and formed cavernous zones in the silt at depth. Elsewhere, the confined water does not reach land surface but rises in wells into the permafrost zone where it becomes frozen, unless the wells are heated or pumped regularly. A search for suitable observation wells in the valley bottom showed that most of the abandoned wells are filled with ice. Records from December 1949 to April 1955 (Cederstrom and Tibbitts, 1961; Waller, 1963, p. 11-12) show that the potentiometric surface had declined 5.7 feet in the U.S. Geological Survey observation well located along the line between sections 13 and 24 south of McGrath Road. From April 1955 to April 1956 water level had recovered 2.5 feet of this decline, but the water in the well had become frozen at a depth of 11 feet by 1962 (R. M. Waller, written commun., 1964).

In other parts of the Fairbanks mining district, water wells and records of water level are sparse. The data available, however, show that conditions in many valleys are similar to those in the Isabella Creek valley. For example, ground water is found in unfrozen alluvium below permafrost in parts of Engineer Creek valley (fig. 14) (Ellsworth and Parker, 1911); the water flows at the surface in a shaft near Steese Highway (Taber, 1943). Most of 

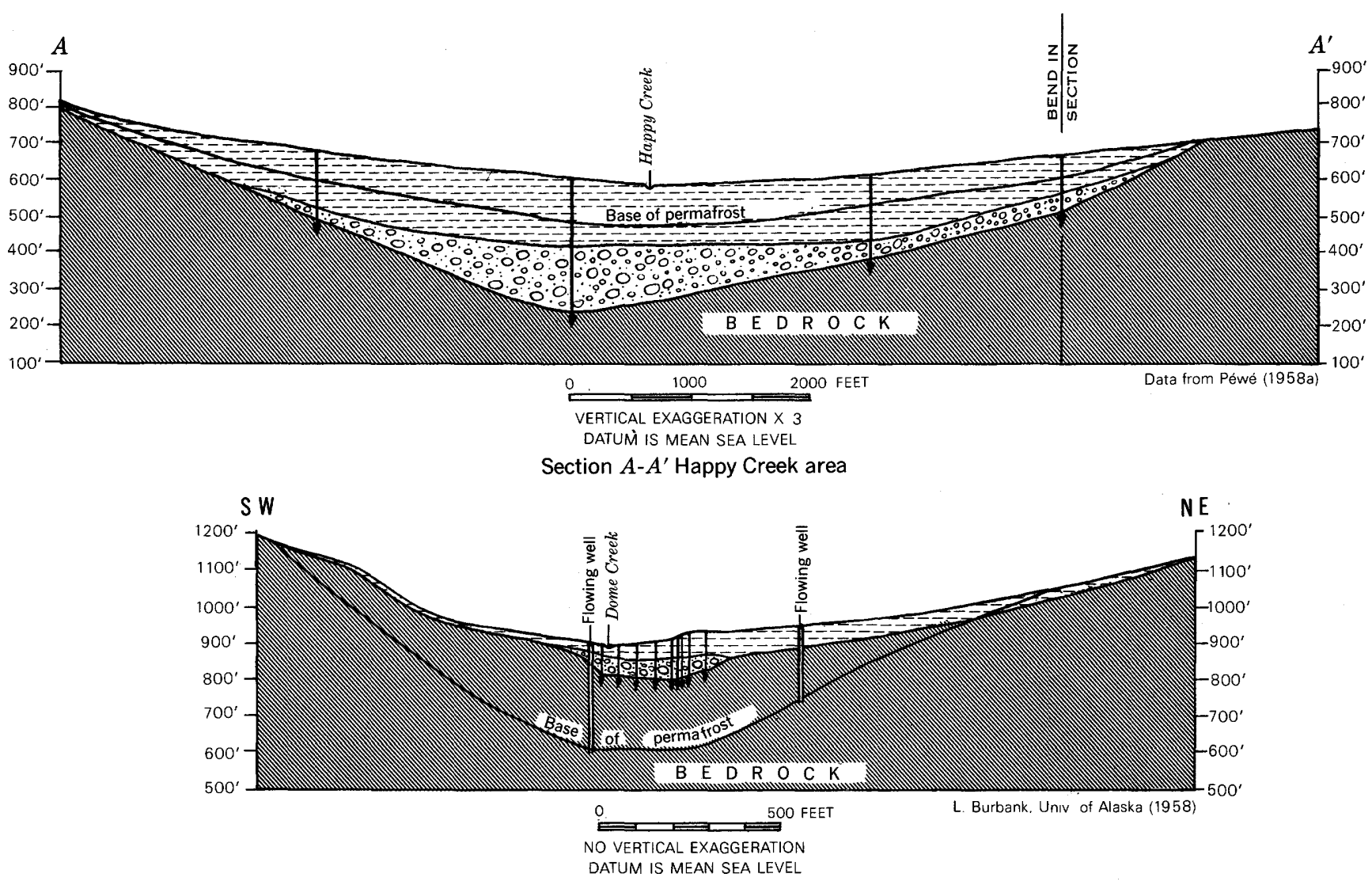

Cross section through Dome Creek Valley

\section{EXPLANATION}

Note: Trace of section $A-A^{\prime}$ shown in figure 14

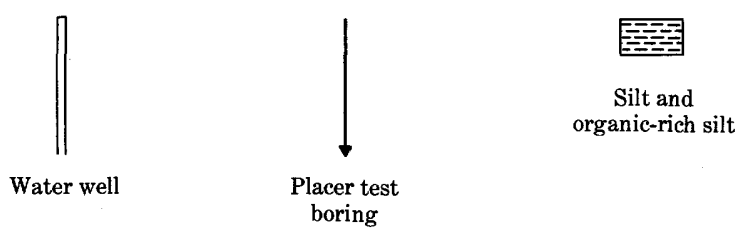

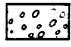

Gravel and sand
Bedrock, chiefly schist

Figure 19.-Permafrost depth through the Happy Creek area and the Dome Creek valley, Fairbanks mining district. 

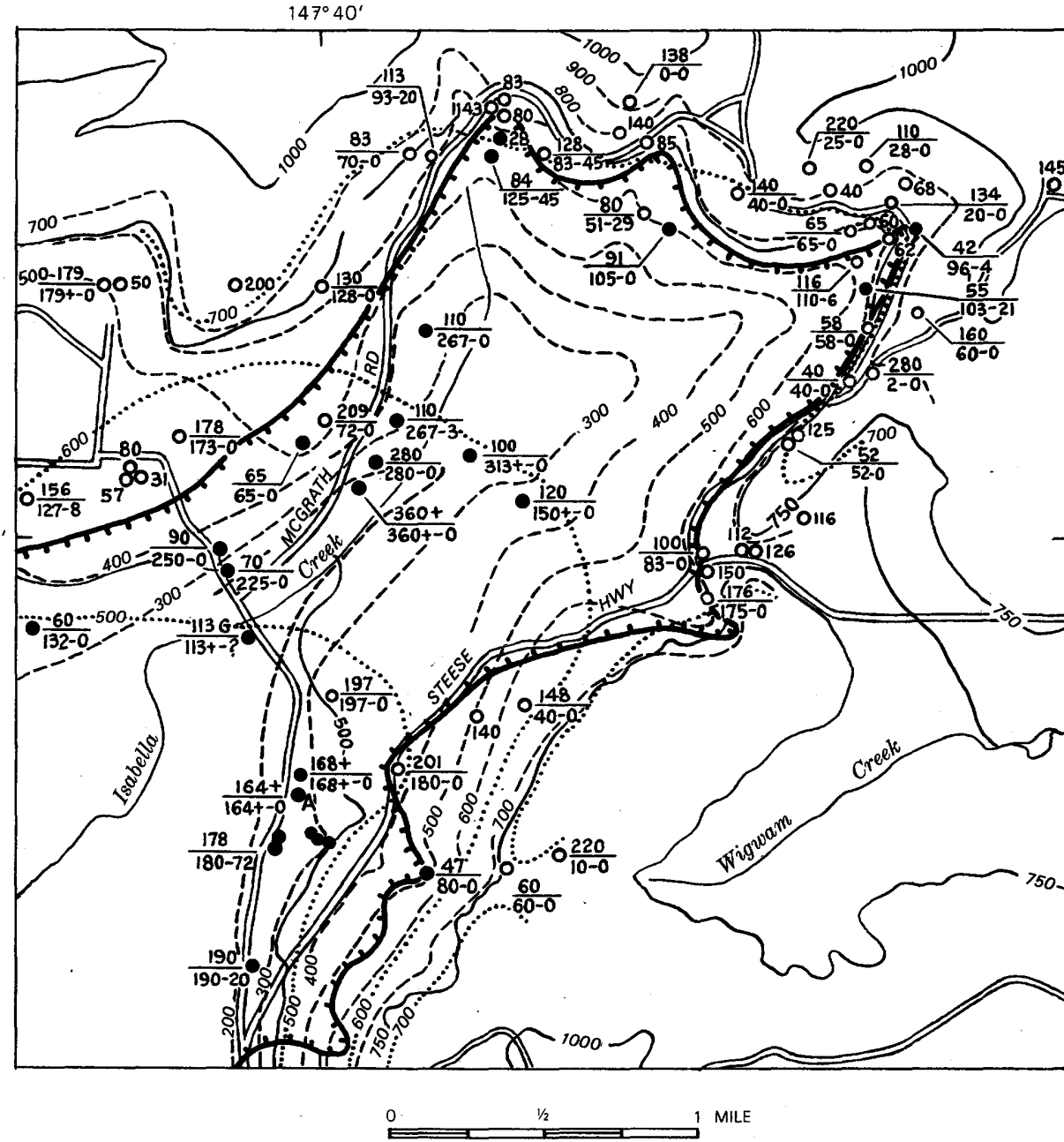

EXPLANATION

Upslope boundary of areas underlain by permafrost.

Ground surface elevation contour

Contour interval 250 feet; datum is mean sea level

Contour showing approximate elevation of bedrock surface Contour interval 100 fedt, datum is mean sea level

$$
\because \cdots \cdots \cdots \cdots
$$

Contour showing approximate elevation of potentiometric surface of water confined beneath silt and permafrost, and water table in wells drilled in unfrozen ground

Contour interval 100 feet; datum is mean sea level

$$
\begin{gathered}
\text { Well } \\
\text { Number is depth to base of frozen ground, in feet; log of hole not } \\
\text { available }
\end{gathered}
$$

Well
Number is depth of well in unfrozen ground, in feet; log of hole
not available
Well drilled in frozen ground
Upper number indicates depth of base of frozen ground, in feet;
lower numbers indicate log of hole, first number is thickness
of silt, second number is thickness of gravel penetrated before
reaching bedrock, in feet. Plus sign beside figure, for perma-
frost, silt, or gravel indicates failure to reach base of that
particular unit
, $\quad$ los
Well drilled in unfrozen ground
Upper number is total depth of hole, in feet below land surface,
lower numbers indicate log of hole, first number is thickness
of silt, second number is thickness of gravel penetrated before
well entered bedrock, in feet. Plus sign beside figure indicates
failure to reach base of that particular unit at total depth

FIGURE 20.-Hydrology of the Isabella Creek valley. 
the alluvium on Fairbanks Creek is frozen (Prindle, 1905), but on Cleary Creek (fig. 14) several shafts were dug through permafrost into water-bearing alluvium or bedrock (Prindle, 1905, 1908b, 1913b; Eakin, 1915a). On Wolf Creek, tributary to Cleary Creek, large flows of ground water were noted in shafts dug below an altitude of 1,500 feet. Water is confined in gravel below the frozen layer on Treasure Creek (Ellsworth, 1910). The alluvium on Goldstream Creek is frozen except in two places near the creek downstream from Happy station (fig. 14) where warming by the creek has kept the alluvium unfrozen (Péwé, 1958a; Péwé and Rivard, 1961).

The exceptionally thick silt and gravel extending below the base of permafrost in the Happy area (figs. 14 and 19) can be traced southwestward into the valleys of Ester and Cripple Creeks (fig. 14). Although the permafrost has a maximum recorded depth of 170 feet on lower Ester and Cripple Creeks, in only a few of 32 placer test holes does it extend to the base of the gravel (Péwé, 1958a; Péwé and Rivard, 1961). Ground water pumped to drain mine workings in this unfrozen gravel beneath permafrost was used for sluicing the placer gold (Prindle, 1913a; Prindle and Katz, 1909).

\section{YUKON-KUSKOKWIM REGION}

Placer mines in the Long-Poorman, Iditarod, and Innoko mining district between the Yukon and Kuskokwim Rivers (fig. 7) provide meager subsurface information on the distribution and thickness of permafrost and on the occurrence of ground water. The extent and thickness of permafrost in the Iditarod and Innoko districts, according to Maddren (1909, p. 240-241), depend on local variations in the texture of the alluvium, the drainage, and the quantity of ground and surface water. He found no uniformity in the distribution and thickness of permafrost, even within small areas, and stated that there is no way to predict where ground water in unfrozen alluvium may be intercepted by wells and shafts.

\section{LONG-POORMAN MINING DISTRICT}

The Long-Poorman district (fig. 7, $64^{\circ} 15^{\prime}$ N., $155^{\circ} 30^{\prime}$ W.) (Maddren, 1910a; Eakin, 1913a, 1914a, b; Mertie and Harrington, 1916, 1924; Brooks, 1922; Mertie, 1936) includes parts of the valleys of Long Creek, Sulatna River, and Poorman Creek. Unconsolidated deposits are generally composed of sand and gravel interbedded with silt, and, in many valleys, the coarse alluvium is covered by many feet of silt. These deposits are generally frozen to bedrock which is less than 75 feet deep on upper Long Creek, at least 125 feet deep on lower Long Creek, and at least 80 feet deep on upper Poorman Creek. Unfrozen, water-bearing gravel is found locally beneath permafrost under the flood plain and terraces bordering Long Creek, south of Long Creek (Mertie, 1936, p. 160-161), and in the valleys of upper Poorman Creek, upper Trail Creek, and a western tributary of Flint Creek. On Midnight and Greenstone Creeks, small eastern tributaries of Sulatna River, the alluvium becomes thicker downstream, but is frozen to bedrock; the unconsolidated deposits in the uppermost reaches of these and other small creeks are reported to be unfrozen. The thickest frozen ground known in the district is on Trail Creek, a western tributary of Sulatna River, where a shaft 185 feet deep failed to reach the base of the frozen alluvium.

Ground water, therefore, is found only in the thin unfrozen alluvial deposits of the uppermost reaches of small creeks, and in local areas beneath the middle and lower reaches of the larger creeks, where the alluvium is thicker than the permafrost. The water in the deep alluvial aquifers is probably confined by the base of frozen ground in these areas. Available data do not suggest a means of predicting the location of these local unfrozen zones.

\section{IDITAROD MINING DISTRICT}

Narrow gulches and valleys of small creeks tributary to the upper Iditarod River (fig. 7, near $62^{\circ} 30^{\prime}$ N., $158^{\circ}$ W.) are underlain by gravelly alluvium that is overlain by silt in many places. The silt and gravel are generally frozen, although unfrozen gravel is found beneath some creeks and in local areas bordering the creeks (Maddren, 1909). On Otter Creek the alluvium is about 12 feet thick and is unfrozen beneath the creek; the alluvium bordering the creek is mantled by frozen silt and is locally unfrozen (Maddren, 1910a, 1911; Brooks, 1915; Mertie, 1936). In summer the water seeps downslope through granite boulders near Flat to form Flat Creek, and downstream the gravelly alluvium of this creek is covered by frozen silt that thickens downvalley (Maddren, 1911). Alluvium on Willow Creek consists of 10-25 feet of silt that contains beds and lenses of gravel; much of this alluvium is unfrozen, and the gravel beds and lenses contain water (Maddren, 1911; Mertie and Harrington, 1916). Near the confluence of Chicken and Bonanza Creeks a 90-foot shaft dug to bedrock reportedly failed to pass through the base of frozen ground. 


\section{INNOKO MINING DISTRICT}

The small creeks of the upper Innoko River valley (fig. 7 , near $63^{\circ} \mathrm{N} ., 156^{\circ} \mathrm{W}$.) are underlain by as much as 30 feet of alluvium. Although the alluvium of many of the narrow valleys and gulches bordering these creeks is generally frozen, the alluvium of the wider valleys and of the Innoko River is locally unfrozen (Maddren, 1909). Alluvium in the valley of Little Creek is $10-30$ feet thick and has unfrozen water-bearing zones in both floodplain and terrace deposits (Maddren, 1911; Eakin, 1913b; Mertie, 1936). Spruce Creek flows on alluvium that contains much silt, and the deposits are frozen (Maddren, 1911). An unfrozen zone in the middle of the gravel paystreak in placer mines on Ophir Creek contains water (Mertie, 1936). The unfrozen, water-bearing gravel beneath Yankee Creek is less than 10 feet thick (Maddren, 1911), and on Ganes Creek the unfrozen gravel, 15 to 20 feet thick, contains water (Brooks, 1908; Eakin, 1913b; Mertie, 1936).

\section{Alaska RANGE}

Alluvium of river valleys within the Alaska Range has been used as a source of ground water in the railbelt between Healy and Windy (fig. 8) and along the Richardson and Glenn Highways. Along the railroad, frozen ground reaches a recorded maximum thickness of 215 feet in the mountains, but large supplies of water are obtained from an 80foot well in unfrozen alluvium of Nenana River 7 miles south of McKinley Park station and from galleries in the alluvium of Healy Creek (fig. 8). In contrast to these large streams, the alluvium beneath a small mountain creek having a steep gradient half a mile west of McKinley Park station was found to be dry in one hole drilled to the top of bedrock in February 1963. At that time the creek was flowing across the top of a thick icing in the streambed, and the ground water that was apparently stored in the creek alluvium had been diverted to the stream flowing on top of the icing or had drained downvalley. Water was found in terrace alluvium beneath 100 feet of frozen ground in a test boring 3 miles north of McKinley Park station (Wahrhaftig, 1958). Springs issuing from terrace gravel near Healy, Garner, Ferry, and Lignite show that those deposits are locally unfrozen and are potential aquifers (Cederstrom and others, 1950).

Two wells, 14 and 65 feet deep, in Paxson, at the junction of Denali and Richardson Highways, produce water from alluvium of the Gulkana River. No frozen ground was reported in these wells. North- ward on the Richardson Highway most wells at Camp Terry, 2 miles south of Rapids, failed to produce water from boulder till containing permeable gravel beds, but a well drilled at the edge of the Delta River penetrated till and produced water from subjacent alluvium. Static level of the water in this well is 56 feet below the surface of Delta River.

A 284-foot well on the alluvial fan of Porcupine Creek, tributary to the Slana River along the Glenn Highway, was drilled through 54 feet of alluvial-fan deposits into underlying glaciolacustrine(?) deposits. The ground is frozen to a depth of 73 feet, and water is pumped from gravel and sand in the interval 120-141 feet below surface.

Ground water has been noted in mine shafts dug in unfrozen alluvium beneath creeks in the Kantishna mining district (fig. 8, near $63^{\circ} 30^{\prime}$ N., $151^{\circ}$ W.), but alluvium of the terraces bordering the streams is reported as generally frozen (Capps, 1919). Prospect shafts in the Chisana area, between the Wrangell Mountains and the eastern extension of the Alaska Range (fig. 8, near $62^{\circ} \mathrm{N}$., $142^{\circ} \mathrm{W}$.), were dug in unfrozen alluvium beneath several creeks. In many of the creek valleys the alluvium is thin and is probably subject to winter freezing, but the deep, unfrozen alluvium beneath Chavolda, Chathenda, Notch, and other large creeks near Chisana is a potential source of year-round supplies of ground water (Brooks, 1914; Martin, 1919).

\section{KilbuCK Mountains}

In the Nyac mining district (fig. $7,61^{\circ}$ N., $160^{\circ}$ W.), the gravel beneath some of the small streams is unfrozen. Ground water has been noted in these unfrozen deposits on Bear Creek, near Nyac, and Marvel Creek (Maddren, 1915; Smith, 1942).

In the Goodnews Bay mining district (fig. 7, 59 ${ }^{\circ}$ N., $162^{\circ}$ W.) northeast of Platinum, permafrost is absent in alluvium in the valleys of Kowkow, Wattamuse, and Bear Creeks (Harrington, 1921) and in the deep alluvium of the Arolik River valley (Smith, 1939). Recent platinum dredging in the district showed that permafrost occurs as occasional lenses in gravel that is 15-60 feet thick (Mining Engineering, 1961, p. 1336).

\section{GLACIAL AND GLACIOLACUSTRINE DEPOSITS OF INTERIOR VALLEYS}

Glacial deposits, consisting largely of till, were laid down as the glaciers advanced from major mountain ranges into the lowlands within the limits shown in figure 2. During the retreat of the glaciers 
relatively permeable water-worked deposits were laid down as kames, eskers, and ice-channel deposits. Permeable beds and lenses of sand and gravel within the till and the recessional deposits are potential aquifers, but the finer grained water-laid deposits and unsorted till are barriers to the movement of ground water. In places where the glaciers advanced into proglacial lakes or into the sea, beds and lenses of clay, silt, gravel, sand, and stony clay or silt are associated with the till. The complex stratigraphy of glacial and glaciolacustrine deposits and the wide range in their porosity and permeability make difficult the evaluation of the role of permafrost as a barrier to ground-water movement in such terranes.

Because it is difficult to discuss glacial and glaciolacustrine deposits separately from alluvial deposits of the coastal lowlands, the glacial deposits in valleys of the southern Brooks Range and in the Tanana River valley have been discussed above under alluvial deposits. Glacial deposits in the coastal lowland near Nome and Kotzebue are discussed briefly in the section on coastal lowlands. The following section is restricted to ground water and permafrost in the glacial and glaciolacustrine deposits of the Copper River Lowland.

\section{COPPER RIVER LOWLAND}

The Copper River Lowland is bounded by the Alaska and Chugach Ranges and the Talkeetna and Wrangell Mountains (fig. 2). It is drained by the Susitna River that flows westward through the Talkeetna Mountains to Cook Inlet and by the Copper River which flows southward to the Gulf of Alaska through a glacier-bordered canyon in the Chugach Range. The peripheral areas of the lowland are underlain by till, ice-contact deposits, and outwash deposited during several episodes of glacial advance from the surrounding mountains into the lowland and during the subsequent glacial retreat. The deposits are locally interbedded with and overlapped by deposits of the series of proglacial lakes that occupied the central part of the lowland in Pleistocene time. The glaciolacustrine deposits are predominantly impermeable silt, clay, and stony silt and clay, but include beds and lenses of permeable, water-laid sand and gravel. After drainage of the last large proglacial lake through the Copper River canyon, the Copper River and its major tributaries cut canyons 200-550 feet deep into the glacial and glaciolacustrine deposits. The stratigraphy and geomorphology of these deposits have been studied by the U.S. Geological Survey since 1952 (Nichols,
1956, 1965; Ferrians and Schmoll, 1957; Ferrians and others, 1958; Ferrians, 1963). The writer's unpublished maps and notes based on geologic mapping 1952-57 also provide much information that is used freely in sections of this report on the Copper River Lowland.

Permafrost is widespread in the unconsolidated deposits of the central part of the lowland and is probably absent only under flood plains and low terraces of the major rivers and beneath large lakes. The ground is frozen from a few feet beneath the surface to a depth of 120-250 feet beneath the former lake bottom into which the rivers are incised (Nichols and Yehle, 1961a, p. 1065).

Potable water occurs in permeable unconsolidated deposits interbedded with impermeable glaciolacustrine and glacial deposits at several places in the Copper River Lowland. The aquifers are below the base of permafrost at Kenney Lake, Chitina, and Junction Inn at the northern junction of Glenn and Richardson Highways (D. R. Nichols, written commun., November 1964). The 205-foot well at Junction Inn was drilled through 155 feet of permafrost.

In the Glennallen-Gulkana airfield area (fig. 16), potable water, produced from permeable sand and gravel in wells 60-218 feet deep, is limited to the valleys of Moose and Dry Creeks (Nichols, 1956). Logs and water-level information are not available for the two fresh-water wells reportedly (Nichols, 1956; written commun., November 1964) drilled through permafrost in the valley of Dry Creek (fig. $\left.19, B-B^{\prime}\right)$. Permeable beds in wells $303,321,330$, and 443 at Gulkana airfield (fig. 16, $B-B^{\prime}$ ), between the reported base of frozen ground and the static level of saline water, are dry, probably because the potentiometric surface of the saline water has dropped in response to canyon cutting by the Copper River and the beds have not been recharged by fresh water. The static level of potable water confined beneath impermeable beds in wells along Moose Creek at Glennallen (fig. 16, $A-A^{\prime}$ ) has been measured during completion tests made at different seasons of the year. The one well that was measured at irregular intervals is pumped heavily. The different static levels of fresh water in each of these wells, therefore, reflect either seasonal or year-to-year changes in the position of the water level, or in the static level of several different aquifers. According to available drillers' logs, the base of frozen ground confines water in only two wells at Glennallen (fig. 16, $A-A^{\prime}$, well 75 and 218), and it 
is unknown whether permafrost or an impermeable bed of clay or silt acts as the confining layer in the wells.

The potable water in the valleys of Moose and Dry Creeks in the Glennallen-Gulkana airfield area is thought by Nichols $(1956$, p. 11) to be the result of downward seepage from the creeks to aquifers beneath the valleys. Alternative sources of recharge along the Moose Creek valley are the small intermittent streams that form alluvial fans north of the Glenn Highway at the edge of the valley (fig. 16). The stratigraphy of the glacial and glaciolacustrine deposits seems to be dominant in controlling the recharge, discharge, movement, and storage of ground water in the Glennallen-Gulkana airfield area. Permafrost apparently has little effect on hydrology near the Copper and Tazlina River. However, it may have a greater effect in sections of the lowland away from the incised stream valleys.

Potable water is discharged from springs along Mendeltna Creek about 15 miles southwest of Lake Louise in the western part of the lowland. The water probably originates in abandoned eastwardtrending outwash channels of the glacial prototype of Little Nelchina River. These channels drain snowmelt, precipitation, and many lakes. The water probably enters the ground through permeable, unfrozen outwash gravel and discharges along the banks and in the bed of Mendeltna Creek. Other known springs of fresh water are east of the Copper River (Nichols, written commun., November 1964). No detailed investigations of the springs have been made, and their relation to permafrost is unknown.

Saline ground water is discharged from springs, artesian wells, and boreholes in an area generally below an altitude of about 2,000 feet southeast, southwest, west, and north of Glennallen (fig. 8), and below 3,200 feet east of the Copper River (Cederstrom, 1952; Moffit, 1954; Nichols, 1956; Nichols and Yehle, 1961a, b; Grantz and others, 1962). The area of greatest salinity lies largely within the area covered by the last proglacial lake.

In the Glennallen-Gulkana airfield area (fig. 16) saline water occurs in wells at depths of about 180-310 feet below land surface (fig. 16, $A-A^{\prime}$, $\left.B-B^{\prime}\right)$, seeps from springs in bluffs bordering the Copper River, and discharges locally into flood-plain and low-terrace alluvium. The water apparently confined by impermeable glaciolacustrine sediments, has a potentiometric surface that slopes toward the Tazlina and Copper Rivers. Away from the canyons of Tazlina and Copper Rivers, the potentiometric surface is probably much nearer or above the land surface, as shown by the borehole 8 miles northwest of Glennallen from which saline water flowed (fig. 16, index map). The water away from the canyons may be partly confined by the base of the frozen layer. But, in the area near the rivers (fig. 16, $\left.A-A^{\prime}, B-B^{\prime}\right)$ the potentiometric surface of the saline water lies below the base of frozen ground as recorded by drillers, and the saline water is apparently confined by beds of till or glaciolacustrine deposits that lie between the saline aquifers and overlying potable-water aquifers (fig. 16, $A-A^{\prime}$, wells $175,182,192,205$, and 218). Separation of saline and potable-water aquifers by impermeable beds is also suggested by lack of noticeable mixing of saline and fresh water in pumping wells at Glennallen (fig. 16, $A-A^{\prime}$, wells $175,182,192,205$, and 218 ), even though the potable-water aquifers lie below the projected static level of the saline water. Slight upward leakage of saline water through the relatively impermeable beds separating the aquifers, or lateral leakage may account for the slightly higher mineral content of some of the fresh water and, therefore, the salinity may increase with more intensive pumping of the fresh-water aquifers.

The origin, distribution, and chemistry of the saline ground water and associated gas in the Copper River Lowland and the unusually high chloride content of some surface waters in the lowland have been discussed in detail by Nichols (1956), Nichols and Yehle (1961a, b), and Grantz and others (1962). Nichols and Yehle (1961a, p. 1080-1081) considered three possible sources of saline water, or combinations thereof: (1) Connate water associated with marine sediments, (2) water fed by volcanic emanations, and (3) meteoric water mixed with saline ground water formed by evaporation from glacial lakes and reconcentrated after drainage of the lakes by the growth of permafrost. They concluded that evidence is insufficient to demonstrate the origin of saline water, and stated (1961a, p. 1085-1086) that saline spring water and ground water are related chemically and that they could be derived, in part, from the three possible sources considered. The gas of springs east of the Copper River probably has a volcanic component and that west of the Copper River "probably originates from buried Cenozoic marsh or coal deposits, or from porous, non-petroliferous beds of preTertiary (Cretaceous?) age" (Nichols and Yehle, 1961a, p. 1086). 
Grantz, White, Whitehead, and Tagg (1962, p. 1990) concluded that the saline water originates in Upper Cretaceous or older marine sedimentary rocks inferred to lie beneath part of the lowland. Two exploratory oil wells drilled in the lowland (after publication of those papers) showed that this thesis is correct. One well, halfway between the southern end of Lake Louise and Ewan Lake, about 28 miles northwest of Glennallen, reportedly reached saline water in bedrock; the other well, south of the Glenn Highway 9 miles west of Glennallen, reached saline water in rocks of Cretaceous age (Arthur Grantz, oral commun., January 1965). Further, as much as $50 \mathrm{ppm}$ (parts per million) of chloride are present in streams draining fresh landslides in the Matanuska Formation of Early and Late Cretaceous age. This chloride concentration is much higher than that of surface streams draining crystalline rocks, and suggests that a small amount of saline ground water from the Cretaceous rocks contributes to the runoff of these creeks.

\section{COASTAL-LOWLAND DEPOSITS}

Coastal lowlands bordering the Arctic Ocean and the Chukchi and Bering Seas range in altitude from sea level at the coast to about 200 or 250 feet above sea level at their landward margin. Underlying the lowlands are marine, fluviatile, deltaic, and lacustrine deposits of Pleistocene and Holocene age. Glacial and glaciomarine sediments are present within the limits of Pleistocene glaciation (fig. 2). Most settlements in the coastal lowland are along rivers or on lakes, bars, spits, beaches, or deltas. The coastal lowlands are divided, for the purpose of describing ground water and permafrost, into the following: (1) Bars, spits, and beaches, (2) deltas of major rivers, (3) the Arctic Coastal Plain, (4) the Nome coastal plain, and (5) Bristol Bay and Cook Inlet lowlands.

\section{BARS, SPITS, AND BEACHES}

Much of the coastal plain bordering the Arctic Ocean is fringed with offshore bars and islands from the Alaska-Yukon boundary westward to Point Lay, from Point Hope southward to Cape Krusenstern, and westward from Cape Espenberg to Cape Prince of Wales (figs. 3-5). South of Cape Prince of Wales, the bars, spits, and beaches along the Bering Sea coastline are separated by rocky headlands. Bars and spits border the outer margin of the Yukon-Kuskokwim delta, but are less common along the shores of Bristol Bay.
BARROW

A beach extends northward along the shore of the Chukchi Sea past Barrow Village and Barrow to a spit that extends 5 miles into the Arctic Ocean to Point Barrow and recurves southeastward from the point (fig. 21). Nuwuk Lake near Point Barrow is 18 feet deep and occupies a depression between the beach ridges. The upper 6 feet of the lake contains fresh water derived from precipitation and snowmelt, but the fresh layer is frozen for all but a few months of the year. The lower layers of the lake are more saline than sea water (Mohr and others, 1961, p. 215), perhaps from concentration of salts by repeated freezing of the surface layers. A shaft about 100 feet from the ocean beach near Point Barrow was dug through frozen clay, gravel, and sand (Ray, 1885; Stefansson, 1910) (table 3). Salt water at a temperature of $-9.4^{\circ} \mathrm{C}$ seeped into the hole from the lower sand and fine gravel.

The base of permafrost near the beach at Barrow (fig. 21) is 667 feet below the land surface (Collins, 1961) (table 3). Permafrost temperature below the level of zero annual amplitude was about $-8^{\circ} \mathrm{C}$ in a hole 350 feet from the shore and was about $-4^{\circ} \mathrm{C}$ in a hole at the edge of the ocean (Brewer, 1958b, fig. 6). A hole was drilled 390 feet offshore to a depth of 120 feet through about 6 feet of sea ice and 12 feet of water. The temperature of the ocean-bottom sediments ranged from $-1^{\circ}$ to $-2^{\circ} \mathrm{C}$ (Brewer, 1958b, fig. 6). The driller's log of this hole indicated: no frozen material to a depth of 100 feet below the sea bottom; some possibility of frozen ground from 100 to 205 feet; and the possible existence of unfrozen layers from 205 to 326 feet, the bottom of the hole. Although the upper 120 feet has temperature below $0^{\circ} \mathrm{C}$ and is permafrost by definition, Brewer $(1958 \mathrm{~b}$, p. 25) stated that the materials are not frozen if they contain sea water and that they would be frozen if they contained fresh water.

Test borings and exploratory wells near the shore at Barrow showed that the beach gravel and underlying materials have a temperature below $0^{\circ} \mathrm{C}$ to a depth of several hundred feet, and that concentrated brine occurs at depths from 10 to 160 feet (Brewer, 1958b, p. 25). The brine, although below $0^{\circ} \mathrm{C}$, remains liquid because its freezing point is lower than that of the permafrost; by definition, the brine is part of the permafrost. The presence of brine within permafrost, the likelihood of saline water below permafrost, and the high permafrost table and deep penetration of winter frost seem to 


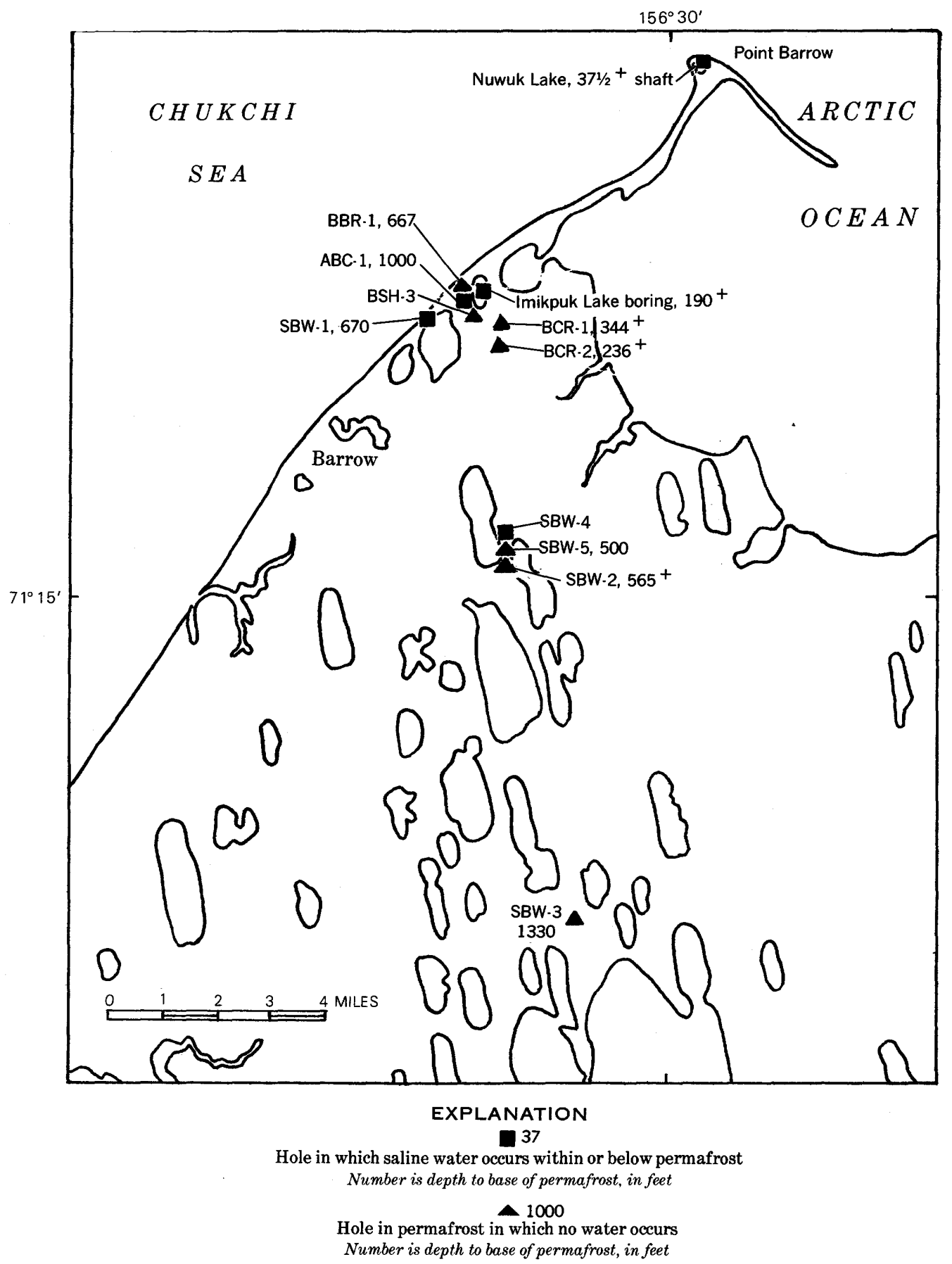

$A B C$-1-Identification number: $A B C$, Arcon Barrow Core Test BBR, Barrow Big Rig Test

BCR, Barrow Core Rig

BSH, Barrow Special Hole

SBW, South Barrow Test Well

FiguRE 21.-Location of test holes in the Barrow area. 
eliminate any possibility of finding a reliable, yearround source of fresh water beneath the beach and spit in the Barrow area. Water is obtained from nearby lakes and from a desalination plant.

\section{PoINT Lay}

A few shallow wells in sand and gravel at Point Lay (fig. 4) formerly provided fresh water in summer, but by 1947 the wells had become brackish. Water is hauled from lakes or from the Kokolik River on the mainland (Chapman and Sable, 1960, p. 60). No information is available on the thickness and extent of permafrost nor on the occurrence of subpermafrost ground water.

\section{PoInt Hope}

The Point Hope spit (fig. 3) consists of wellsorted, frozen sand and gravel. A well dug 4 feet to the top of permafrost southeast of the village provides a basin or sump in which snowmelt and precipitation filtering through the active layer can collect. The source of supply freezes in winter (Cederstrom, 1952; Waller, 1957b). No information is available on the thickness of permafrost nor on the possibilities for subpermafrost water.

\section{KOTZEBUE}

Kotzebue is on a recurved spit, separated from the northern end of Baldwin Peninsula by a shallow brackish-water lagoon (figs. 4 and 22). The lagoon, fed by small intermittent streams and connected to the sea at one end, freezes nearly to the bottom each winter. The largest of the streams, June Creek, supplies water in summer for use in the village and in Government installations.

Sand and gravel of the spit is from 4 to 20 feet thick, and lies on silt, sand, fine gravel, and black organic-rich silt and sand. These deposits are probably part of the sequence of marine and glacial deposits exposed in sea cliffs along Baldwin Peninsula (Hershey, 1909; Hopkins and others, 1962) and those penetrated between 19 and 325 feet in the U.S. Geological Survey test well on the spit (Cederstrom, 1952, 1961a). This well (fig. 22) was drilled through the following materials :

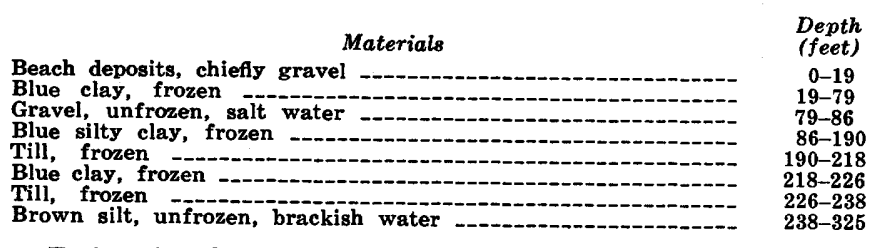

Brine in the liquid state, but probably below $0^{\circ} \mathrm{C}$, occurs in gravel from 79 to 86 feet. Brackish water beneath the base of frozen ground at 238 feet increases in salinity with depth (Cederstrom, 1961a). Because of the depressed freezing point of the brine and the brackish water, evaluation of the extent of permafrost in the test well is impossible without temperature measurements. Permafrost probably is continuous from a depth of 19-238 feet, and temperature below $0^{\circ} \mathrm{C}$ may extend below 238 feet. A well at the Federal Aviation Administration station (fig. 22) was drilled through similar materials, including unfrozen (but probably below $0^{\circ} \mathrm{C}$ ) sand and silt from 67 to 83 feet, and gravel containing brine from 83 to 85 feet. The well failed to reach the base of frozen ground at a depth of 95 feet. The failure of these two wells to produce potable water from permeable beds beneath the spit gravel and the indicated increase in salinity of water beneath the frozen layer seem to eliminate the possibility of obtaining potable water below the lower limit of frozen ground.

Potable suprapermafrost water in the spit gravel, 4-20 feet thick, and in underlying sand has been developed in several domestic and public-supply wells and has been reached in test borings (Cederstrom, 1952, p. 34; Lamphere and Page, 1956). The permafrost table which forms the lower limit of the aquifer generally parallels undulations in the land surface $\left(A-A^{\prime}\right.$, fig. 17). The high permafrost table beneath ridges in the surface of the spit prevents seaward flow of water in the aquifer and helps prevent contamination of the aquifer by sea water during high storm tides (Broadwell, 1945). Water is recharged into these deposits in summer from precipitation and snowmelt but in winter, when the ground is frozen and air temperature is continually below $0^{\circ} \mathrm{C}$, no recharge from the surface takes place.

Storage and movement of ground water within the suprapermafrost aquifer are affected by thickness of the aquifer, by depth and configuration of the permafrost table, and by rate and depth of penetration of winter freezing. Where the aquifer is thin, the ground water is wholly or partly subject to freezing in winter, and water is available only in summer. Where the gravel is thick, only the upper part of the aquifer freezes in winter. That part of the aquifer which lies between the base of seasonal frost and the permafrost table provides a small volume of unfrozen gravel in which water may be stored. Pumping causes persistent declines in water level during the winter and failure of many wells. Especially rapid decline in water level may be experienced locally when seasonal frost reaches the per- 


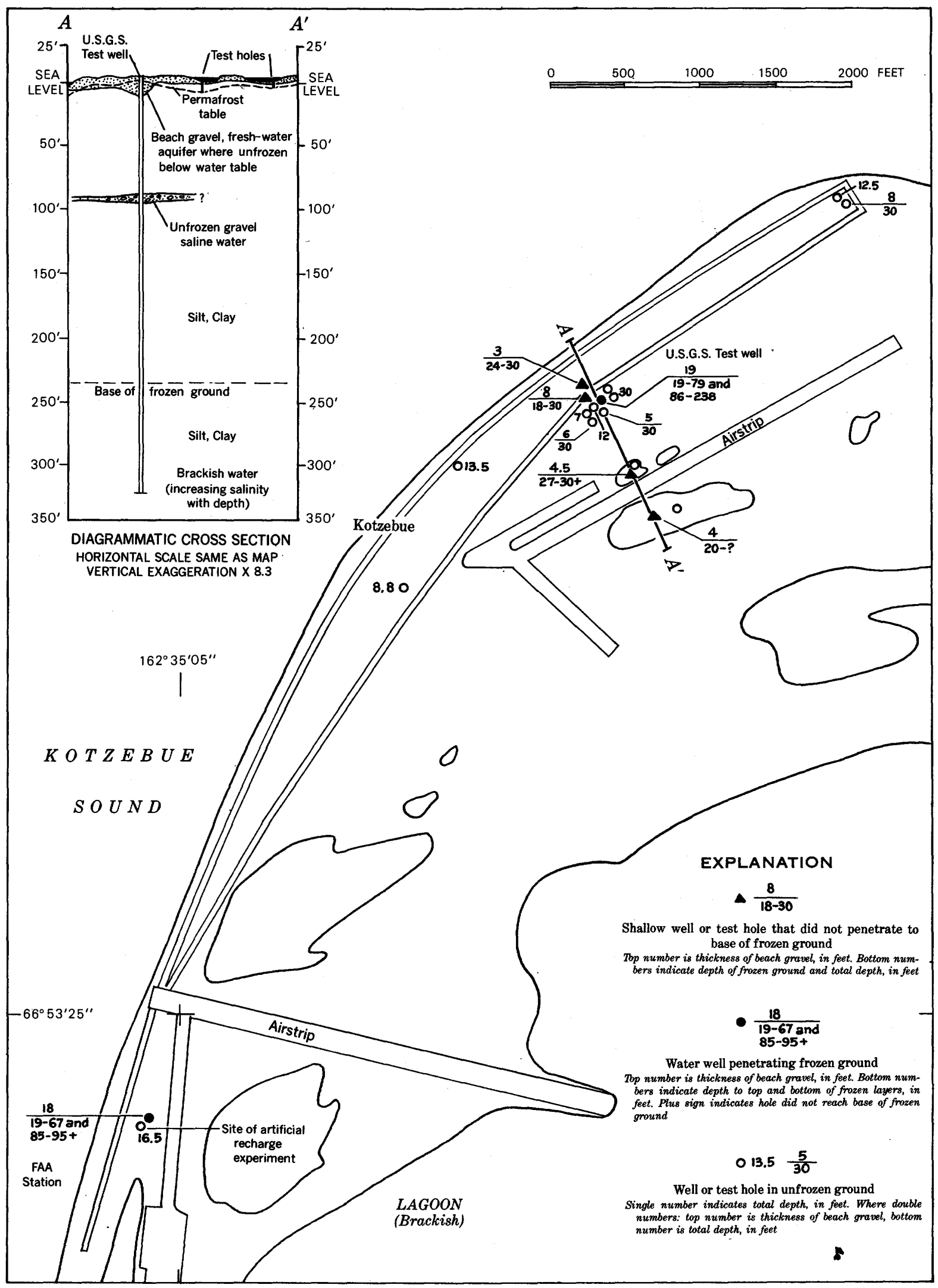

Figure 22.-Location of wells and test holes at Kotzebue. 
mafrost table and blocks lateral movement of water in the unfrozen aquifer. Equally sudden rise in water level in spring is apparently caused by snowmelt percolating through the unsaturated frozen gravel within the cone of depression of a well that was being pumped heavily in the fall. On the other hand, Cederstrom $(1952$, p. 35) attributed the rapid rise to a sudden release of water trapped between seasonal frost and permafrost as a permeable zone becomes unfrozen. Year-to-year differences in the rate of formation of seasonal frost, in the depth to which it penetrates, in snow cover and precipitation, and in long-term changes in the thermal regimen of permafrost affect the hydrology of the suprapermafrost aquifer at Kotzebue.

Experimental recharge of the shallow aquifer in a well near the beach in the Federal Aviation Administration area (fig. 17) failed to provide a perennial supply of ground water (Lamphere and Page, 1956). Water, recharged into the aquifer at a rate of $20 \mathrm{gpm}$ during the summer, apparently spread laterally in the thin aquifer. The water either became frozen the following winter or was prevented from moving to the pumping well by merging of the seasonal frost and permafrost. Most of the water recharged into the aquifer may have been discharged to the sea.

Test holes were drilled beneath shallow lakes on the spit (fig. 22, $A-A^{\prime}$ ) by U.S. Public Health Service (Lamphere and Page, 1956) in an unsuccessful attempt to obtain a satisfactory source of water from the spit deposits. As much as 20 feet of unfrozen sand and silt was found between the base of seasonal frost and the permafrost table beneath the lakes (fig. 22, $A-A^{\prime}$ ). However, the silt and sand within the unfrozen zone yielded little water.

\section{TELLFR}

Teller lies on a narrow spit on the Bering Sea coast of Seward Peninsula (fig. 3). It is separated from Grantley Harbor by a fresh-water lagoon that is kept at an altitude of 4 feet above sea level by a dam (Cederstrom, 1952, p. 34). Wells on the spit are about 20 feet deep, and water level is about 12 feet below land surface. Ground water apparently moves from the lagoon seaward through the spit gravel (Cederstrom, 1952, p. 34), and when the lagoon and village are flooded by high storm tides, saline water contaminates the wells.

\section{POINT SPENCER}

Point Spencer spit separates Port Clarence from the Bering Sea near the west end of Seward Penin- sula (figs. 3 and 23). Two wells were drilled through 34 and 36 feet of beach or spit gravel and sand. Beneath these deposits, the wells penetrated black muck and alternating beds of black clay, black silt, sand, and gravel, which extended to a depth greater than 298 feet (Black, 1958). The base of frozen gravel in the wells was 12 and 17 feet, and salt water in the underlying unfrozen deposits confined by the base of permafrost rose to within 5 and 9 feet of land surface.

In an investigation of the suprapermafrost water, Black (1958) found that the permafrost table was higher beneath beach ridges than beneath depressions and ponds. Ground water above permafrost was found in deposits of spit gravel that were subject to winter freezing. Development of year-round supplies of water required erection of snow fences to insulate the ground against penetration of seasonal frost and to increase the recharge from snowmelt in summer. The high permafrost table beneath beach ridges facing the sea and Port Clarence (fig. 23) acts as a barrier to contamination of the suprapermafrost water by salt water during high storm tides and retards the flow of suprapermafrost water to the sea. The frozen ground forms an impermeable boundary that separates the fresh water from underlying salt water beneath the spit.

\section{ShaKTOOLIK}

The village of Shaktoolik lies on a bar between the Bering Sea and a point on the Shaktoolik River 4 miles above its mouth (fig. 6). The bar gravel extends to a depth greater than 10 feet, and permafrost probably lies at a depth greater than 10 feet, if present (Waller, 1959b). Fresh water moves from the river through the bar gravel to the sea, but the role of permafrost in creating a barrier to ground-water flow is unknown. The school well, 19 feet deep, was abandoned when it produced salt water, but recently it has yielded fresh water (Waller, 1959b). Excessive pumping of the well or high storm tides probably made the well water saline.

\section{TANUNAK}

Tanunak village lies on a narrow spit across the mouth of the Tanunak River on the west coast of Nelson Island, along the outer fringe of the YukonKuskokwim delta (fig. 6). The spit is $\mathbf{1 0}$ feet above sea level and is composed of gravel. A 14-foot well on the river side of the spit produces fresh water, evidently recharged into the gravel from the river 
(Waller, 1958). That well and another, 36 feet deep, failed to reach permafrost.

\section{Gambell, St. Lawrence IsLand}

Gambell, on northwestern St. Lawrence Island (fig. 3) is on a gravel spit that separates a large fresh-water lake from the sea. The lake, about 10 feet deep, is 4 feet above sea level, and water apparently moves from the lake through permeable gravel of the spit to the sea. According to Waller (1959a), permafrost found locally in the spit gravel may act as a barrier that separates the lake water and the sea water.

\section{DELTAS OF MAJOR RIVERS}

Deltas of the Colville, Noatak, Kobuk, and Selawik Rivers and the compound delta of the Yukon and Kuskokwim Rivers form a large part of the coastal lowlands of northern and western Alaska (figs. 3-6). Subsurface data are available only from the Yukon-Kuskokwim delta.
Sediments of the Yukon-Kuskokwim delta consist of sand, silt, and thin beds of gravel. Organic material is common in the silt and sand. These deposits, of Quaternary age and perhaps older, are nearly 1,000 feet thick in an exploratory oil well drilled about 30 miles west-southwest of Bethel (T. L. Péwé, written commun., March 1963) and near Bethel the deposits are more than 650 feet thick. Organic material from a depth of about 600 feet in the well near Bethel has been dated (W-1287, Ives and others, 1964, p. 60 ) as older than 34,000 years by the radiometric method (Feulner and Schupp, 1964).

Permafrost is widespread in the upper part of the deltaic deposits. It extends from near the surface to a maximum known depth of 603 feet in the dissected terrace that forms the older part of the delta west of Bethel, in contrast to the absence of permafrost beneath the nearby Kuskokwim River (fig. 15). Westward, in the outer fringe of the delta, permafrost is thinner because of the more recent

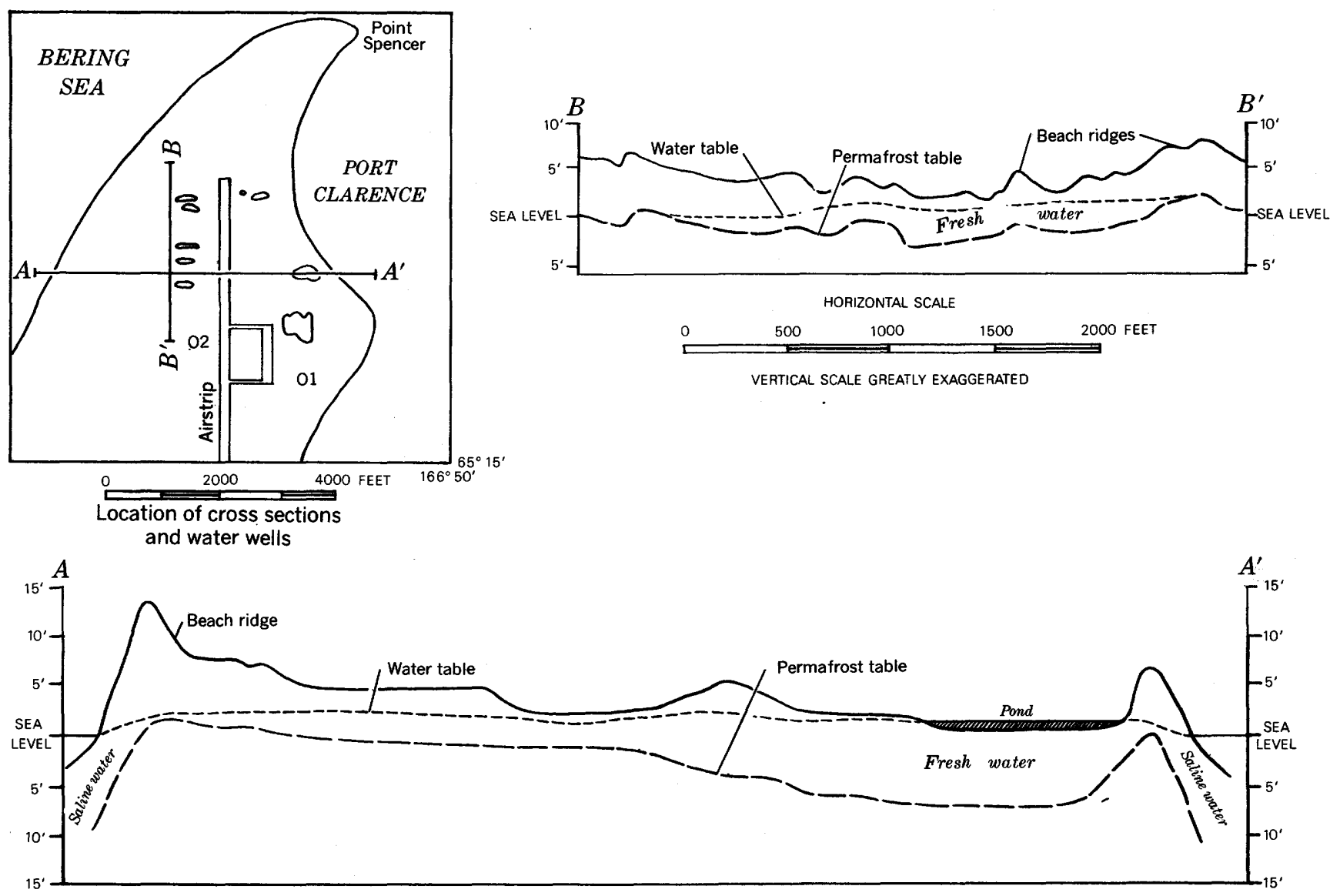

Figure 23.-Relation of permafrost table to topography and to ground-water conditions, Point Spencer spit, Seward Peninsula. 
age of the outer part of the delta or because of the greater thermal effect of numerous large lakes and sluggish rivers near the sea. The few records from the outer fringe of the delta (fig. 7) show that permafrost is generally less than 250 feet thick. However, a 159-foot well at Kotlik was reportedly drilled in unfrozen ground, but the salinity of the ground water may have depressed the freezing point of the water in the sediments sufficiently to keep them unfrozen, even though below $0^{\circ} \mathrm{C}$.

Ground water in deltaic sand and in thin beds of gravel is confined beneath permafrost. It rises in wells near Bethel (fig. 15) to a static level that is approximately that of the Kuskokwim River, and its level apparently fluctuates with tides and changes in stage of the river (Waller, 1957a). The absence of permafrost beneath the river and the similarity between fluctuations in water levels in wells drilled through permafrost and changes in river level suggest that the subpermafrost water in the deltaic deposits near Bethel is connected hydraulically to the Kuskokwim River (Waller, 1957a). The water below permafrost is potable at Bethel, Nunapitchuk, Kasigluk, and Sheldon Point, but is saline at Kotlik. Due to scarcity of well data, it is not yet possible to locate the fresh water-saline water interface in the deltaic deposits beneath the permafrost.

\section{ARCTIC COASTAL PLAIN}

The broad, lake-dotted, tundra-covered Arctic Coastal Plain extends along the south shore of the Arctic Ocean from the western end of the Brooks Range near Cape Lisburne to the Alaska-Yukon boundary (figs. 3-5). It is underlain by as much as 150 feet of unconsolidated silt, sand, and gravel of the Gubik Formation of Pleistocene age (Payne and others, 1952; Black, 1957, 1964; Coulter and others, 1960). The Gubik Formation includes deposits of interglacial marine transgressions, alluvium, and lake sediments. The sediments are covered locally by sand dunes (Black, 1951) and lie unconformably on siltstone and sandstone chiefly of Mesozoic age (Payne and others, 1952). The subsurface geology was investigated during exploration of Naval Petroleum Reserve No. 4 by a number of test wells and core tests (table 3 ). Geothermal studies of permafrost were made in some of these test holes and have been continued in selected holes (Lachenbruch, 1957a, b; Lachenbruch and Brewer, 1959, 1962; Lachenbruch and others, 1962). Geothermal data on individual wells have been summarized by Brewer (in Collins, 1961; in Robinson, 1964).
Permafrost in the Arctic Coastal Plain ranges in thickness from 500 to 1,330 feet (table 3), and its minimum temperature as measured in wells below the level of zero annual amplitude ranges from $-5.5^{\circ}$ to $-10.6^{\circ} \mathrm{C}$ (Brewer, 1958b, fig. 10) (fig. 9). Although the permafrost is continuous and thick, the large number of lakes and rivers and the proximity to the sea affect its thermal regimen and thickness, as shown in the earlier discussion of permafrost. Because of the prevalence of brackish or saline ground water in the Arctic Coastal Plain, the only reliable record of the lower limit of permafrost is that of temperature measurements (table 3 ), such as, for example, the measurement of the $0^{\circ} \mathrm{C}$ isogeotherm at a depth of 190 feet beneath Imikpuk Lake (Brewer, 1958a, p. 284). Drilling and seismic studies beneath saline Sinclair Lake (Lake Minga) near Cape Simpson (fig. 24) indicated little, if any, frozen ground. Theoretically, this lake, 61/2 miles long and $21 / 2$ miles wide, should be large enough to generate a zone temperature above $0^{\circ} \mathrm{C}$ that would perforate the permafrost. Data ${ }^{3}$ obtained before the hole had reached thermal equilibrium showed that if the ground water in bedrock were fresh, it would be frozen to a depth of at least 800 feet, where the temperature was $-0.7^{\circ} \mathrm{C}$. If the water in the bedrock were saline, like that of the lake, the minimum temperature of $-2.7^{\circ}$ at a depth of 480 feet would not have been low enough to freeze the ground water, and the bedrock would have been within the permafrost zone, by definition, although not cemented by ice.

Ground water beneath frozen ground in rocks of Mesozoic age is brackish to saline in most of the deep exploratory wells and core tests drilled in the coastal plain (table 3). Water in Square Lake test well 1 (30 miles northwest of Umiat) (fig. 4; table 3 ) is relatively fresh in comparison with ground water sampled in other wells. The origin of the brackish and saline water in bedrock is unknown, but it is probably either connate or inherited from one or more marine transgressions of the Pleistocene Epoch. The role of permafrost is to prevent downward migration of fresh water into bedrock, and in at least one well, Arcon core test 1 (fig. 21; table 3) to confine the saline water at the base of frozen ground. The temperature of the intrapermafrost brine in Barrow special hole 3 (table 3) was reported to be $-10^{\circ} \mathrm{C}$, and the brine occurred in several lenses at depths from 10 to 160 feet at Barrow (Brewer, 1958b, p. 25).

\footnotetext{
3 MacCarthy, G. R., undated, Minga velocity test well No. 1, U.S. Geol.
} 
TABLE 3.-Data on permafrost and ground

\begin{tabular}{|c|c|c|c|c|c|}
\hline $\begin{array}{l}\text { Name, type, } \\
\text { and loca- } \\
\text { tion of } \\
\text { well }\end{array}$ & $\begin{array}{l}\text { Total } \\
\text { depth } \\
\text { (feet) }\end{array}$ & $\begin{array}{l}\text { Depth to } \\
\text { base of } \\
\text { perma- } \\
\text { frost } \\
\text { (feet) }\end{array}$ & \multicolumn{2}{|c|}{$\begin{array}{l}\text { Temperature } \\
\text { of perma- } \\
\text { frost o } \\
\text { at depth } \\
\text { (feet) }\end{array}$} & $\begin{array}{l}\text { Ground-water occur- } \\
\text { rence and yield; } \\
\text { results of forma- } \\
\text { tion tests }\end{array}$ \\
\hline \multicolumn{6}{|l|}{$\begin{array}{l}\text { Barrow } \\
\text { area, } \\
\text { fig } 21:\end{array}$} \\
\hline $\begin{array}{l}\text { Shaft } \\
\text { near } \\
\text { Point } \\
\text { Barrow. }\end{array}$ & $371 / 2+$ & $371 / 2+$ & -- & -- & $\begin{array}{l}\text { Brine within perma- } \\
\text { frost at }-9.4 \mathrm{C} \text {. }\end{array}$ \\
\hline $\begin{array}{l}\text { Barrow } \\
\text { Special } \\
\text { hole } 3 .\end{array}$ & $125+$ & $125+$ & -- & -- & $\begin{array}{l}\text { Brine within perma- } \\
\text { frost at }-10 \mathrm{C} .\end{array}$ \\
\hline $\begin{array}{l}\text { Well, } \\
\text { Barrow } \\
\text { water } \\
\text { system } \\
\text { (not } \\
\text { located } \\
\text { on map. }\end{array}$ & 101 & -- & -- & -- & $\begin{array}{l}\text { Brackish or saline } \\
\text { water in mud under } \\
\text { fresh-water lake. }\end{array}$ \\
\hline $\begin{array}{l}\text { Boring, } \\
\text { Imikpuk } \\
\text { Lake. }\end{array}$ & 200 & Top at 190 & -- & -- & $\begin{array}{l}\text { Brackish or saline } \\
\text { water in sediments } \\
\text { under lake. }\end{array}$ \\
\hline $\begin{array}{l}\text { Arcon } \\
\text { core } \\
\text { test } 1\end{array}$ & 1,442 & $1,000 ?$ & -- & -- & $\begin{array}{l}\text { Water below perma- } \\
\text { frost rose to } 125 \\
\text { ft; could not be } \\
\text { lowered by bailing. }\end{array}$ \\
\hline $\begin{array}{l}\text { Big Rig } \\
\text { test } 1 .\end{array}$ & 685 & $667 ?$ & -- & -- & 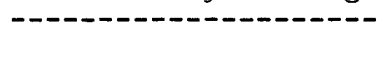 \\
\hline $\begin{array}{l}\text { South } \\
\text { Barrow } \\
\text { test } \\
\text { well } 1 .\end{array}$ & 3,553 & 670 & -7.5 & 90 & $\begin{array}{l}\text { Salt water entered } \\
\text { hole after it } \\
\text { reached total } \\
\text { depth. }\end{array}$ \\
\hline $\begin{array}{l}\text { South } \\
\text { Barrow } \\
\text { test } \\
\text { well } 2 \text {. }\end{array}$ & 2,505 & $565+$ & -- & -- & 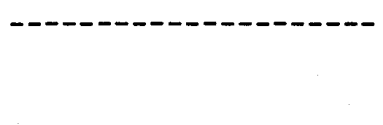 \\
\hline $\begin{array}{l}\text { South } \\
\text { Barrow } \\
\text { test } \\
\text { well } 3 \text {. }\end{array}$ & 2,900 & 1,330 & -9.0 & 60 & - - - - - \\
\hline $\begin{array}{l}\text { South } \\
\text { Barrow } \\
\text { test } \\
\text { well } 4 .\end{array}$ & 2,538 & -- & -- & -- & $\begin{array}{l}\text { Salt spray occurring } \\
\text { with gas from } \\
2,472-2,538 \mathrm{ft} .\end{array}$ \\
\hline $\begin{array}{l}\text { South } \\
\text { Barrow } \\
\text { test } \\
\text { well } 5 .\end{array}$ & 2,456 & $500 ?$ & -- & -- & - - - \\
\hline \multicolumn{6}{|l|}{$\begin{array}{l}\text { Cape simp- } \\
\text { son area, } \\
\text { fig } 24:\end{array}$} \\
\hline $\begin{array}{l}\text { Simpson } \\
\text { test } \\
\text { well } 1 .\end{array}$ & 7,002 & 1,000 & -- & -- & $\begin{array}{l}\text { Water content of } \\
\text { frozen cores from } \\
218-405 \text { ft unusu- } \\
\text { ally low for con- } \\
\text { nate water. Water } \\
\text { from } 6,153-7,002 \\
\text { ft. }\end{array}$ \\
\hline
\end{tabular}

\footnotetext{
${ }^{1}$ Analyses by U.S. Bur. Mines.
} 
water in the Arctic coastal plain

Quality of water constituents in milligrams per liter

\begin{tabular}{|c|c|c|c|c|c|c|c|c|c|}
\hline $\mathrm{Ca}$ & $\mathrm{Mg}$ & $\mathrm{Na}$ & $\mathrm{HCO}_{3}$ & $\mathrm{SO}_{4}$ & $\mathrm{Cl}$ & other & $\begin{array}{l}\text { Total } \\
\text { solids }\end{array}$ & $\begin{array}{l}\text { Salin- } \\
\text { ity }\end{array}$ & $\begin{array}{l}\text { Sources of in- } \\
\text { formation for } \\
\text { quality of } \\
\text { water }\end{array}$ \\
\hline
\end{tabular}

$\longrightarrow$

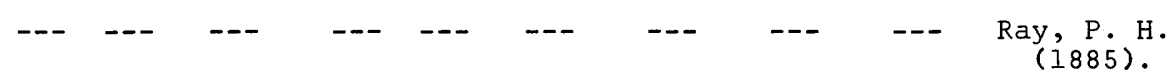

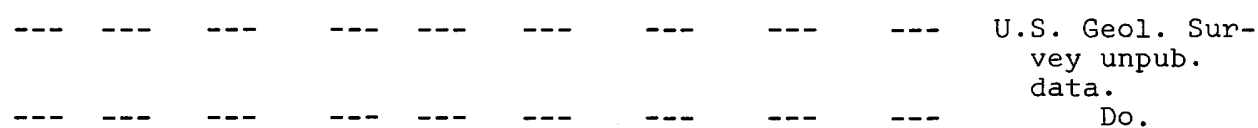

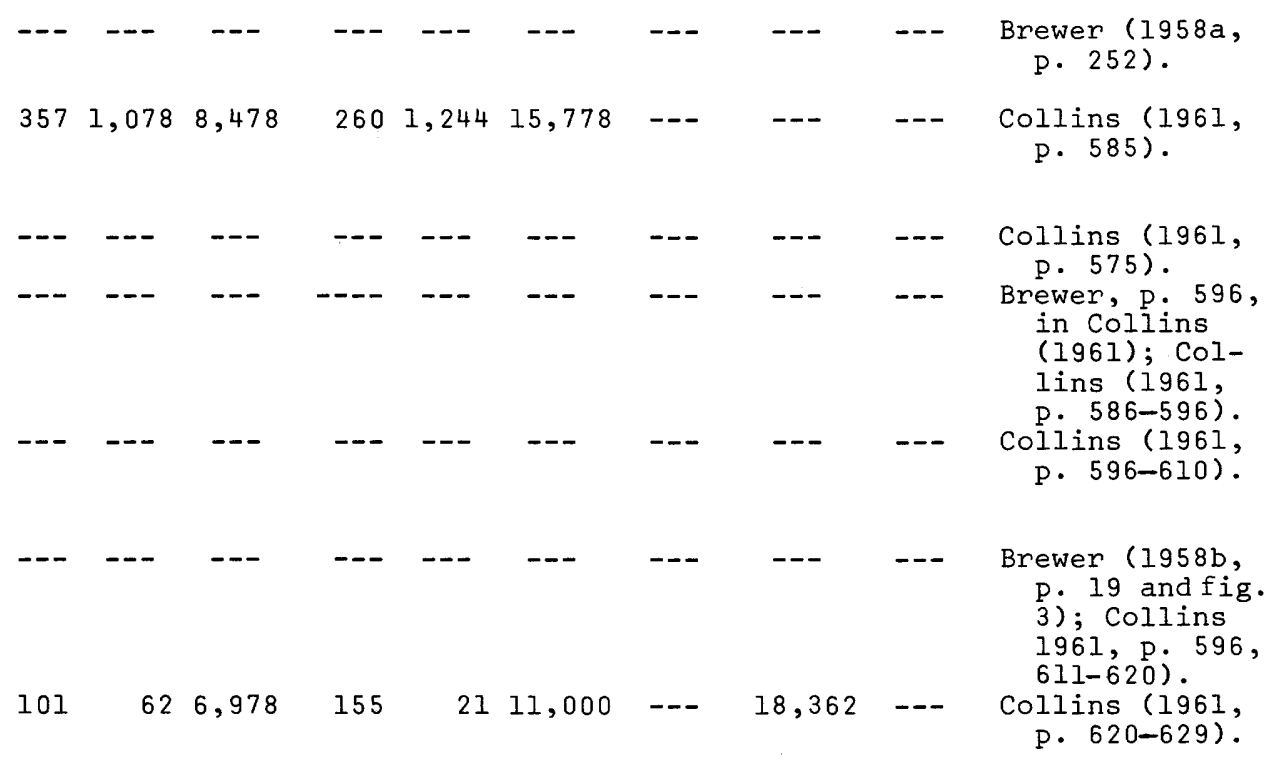

-- -- - - - - - - - - - - - - - -

p. 640-641).

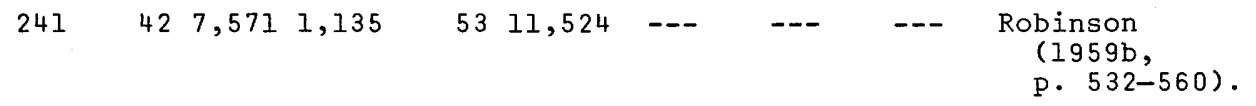


TABLE 3.-Data on permafrost and ground

\begin{tabular}{|c|c|c|c|c|c|}
\hline $\begin{array}{l}\text { Name, type, } \\
\text { and loca- } \\
\text { tion of } \\
\text { well }\end{array}$ & $\begin{array}{l}\text { Total } \\
\text { depth } \\
\text { (feet) }\end{array}$ & $\begin{array}{l}\text { Depth to } \\
\text { base of } \\
\text { perma- } \\
\text { frost } \\
\text { (feet) }\end{array}$ & \multicolumn{2}{|c|}{$\begin{array}{l}\text { Temperature } \\
\text { of perma- } \\
\text { frost }{ }^{\circ} \mathrm{C} \\
\text { at depth } \\
\text { (feet) }\end{array}$} & $\begin{array}{l}\text { Ground-water occur- } \\
\text { rence and yield; } \\
\text { results of forma- } \\
\text { tion tests }\end{array}$ \\
\hline \multicolumn{6}{|l|}{$\begin{array}{l}\text { Camp simp- } \\
\text { son area, } \\
\text { fig } 24-- \\
\text { Continued }\end{array}$} \\
\hline $\begin{array}{l}\text { North } \\
\text { Simpson } \\
\text { test } \\
\text { well } 1 .\end{array}$ & 3,774 & $500+$ & -- & -- & 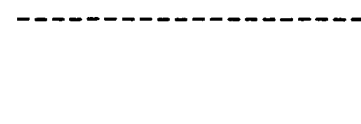 \\
\hline $\begin{array}{l}\text { Simpson } \\
\text { core } \\
\text { test } \\
13 .\end{array}$ & 1,438 & 1,050 & -9.87 & 120 & 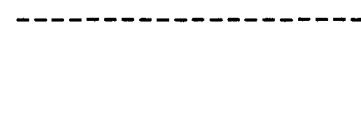 \\
\hline $\begin{array}{l}\text { Simpson } \\
\text { core } \\
\text { test } \\
21\end{array}$ & 1,500 & 820 & -9.90 & 100 & 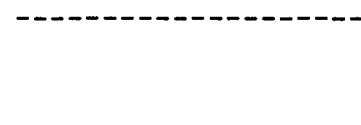 \\
\hline $\begin{array}{l}\text { Simpson } \\
\text { core } \\
\text { test } \\
28\end{array}$ & 2,505 & 910 & -9.84 & 90 & 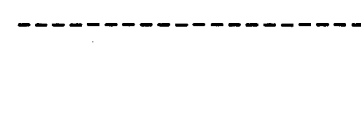 \\
\hline $\begin{array}{l}\text { Simpson } \\
\text { core } \\
\text { test } \\
29 .\end{array}$ & 700 & $\begin{array}{c}950 \\
\text { (calculated) }\end{array}$ & -9.82 & 90 & 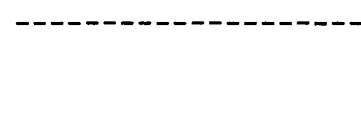 \\
\hline \multicolumn{6}{|l|}{$\begin{array}{l}\text { other } \\
\text { areas, } \\
\text { fig 4: }\end{array}$} \\
\hline $\begin{array}{l}\text { Fish } \\
\text { Creek } \\
\text { test } \\
\text { well } 1 .\end{array}$ & 7,020 & 600 & -- & -- & $\begin{array}{l}\text { Saline water having } \\
\text { temperature below } \\
0^{\circ} \mathrm{C} \text { may occur be- } \\
\text { low } 600 \mathrm{ft} \text {, the } \\
\text { lower limit of } \\
\text { frozen ground, ac- } \\
\text { cording to drill- } \\
\text { er's log. }\end{array}$ \\
\hline $\begin{array}{l}\text { Kaolak } \\
\text { test } \\
\text { well } 1 .\end{array}$ & 6,952 & $850-980$ & -- & -- & $\begin{array}{l}\text { The few sandstone } \\
\text { beds penetrated } \\
\text { are relatively im- } \\
\text { permeable, but } \\
\text { water bearing. }\end{array}$ \\
\hline $\begin{array}{l}\text { Skull } \\
\text { Cliff } \\
\text { core } \\
\text { test } 1 .\end{array}$ & 779 & $779+$ & -9.6 & $\begin{array}{r}100- \\
200\end{array}$ & 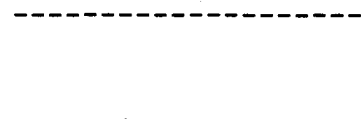 \\
\hline $\begin{array}{l}\text { Square } \\
\text { Lake } \\
\text { test } \\
\text { well } 1 .\end{array}$ & 3,987 & $713+$ & -- & -- & $\begin{array}{l}\text { Formation tests. } \\
\text { Drilling mud cut } \\
\text { by water: } \\
\text { 1,847-1,879. } \\
\text { Water recovered: } \\
\text { 1,646-1,675- } \\
\text { 3,033-3,067-- }\end{array}$ \\
\hline $\begin{array}{l}\text { East } \\
\text { Topa- } \\
\text { goruk } \\
\text { test } \\
\text { well } 1 .\end{array}$ & 3,589 & -- & -- & -- & $\begin{array}{l}\text { Brackish water cut } \\
\text { by gas at 2,216- } \\
2,256 \text {. }\end{array}$ \\
\hline $\begin{array}{l}\text { Topago- } \\
\text { ruk } \\
\text { test } \\
\text { well } 1 .\end{array}$ & 10,503 & 1,100 & -- & -- & 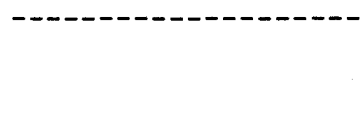 \\
\hline
\end{tabular}

\footnotetext{
${ }^{1}$ Analyses by U.S. Bur. Mines.
} 
water in the Arctic coastal plain-Continued

Quality of water constituents in milligrams per liter

Ca $\mathrm{Mg} \quad \mathrm{Na} \quad \mathrm{HCO}_{3} \mathrm{SO}_{4}$ Cl other Total Salin-Sources of insolids ity formation for quality of

\begin{tabular}{|c|c|c|c|c|c|c|c|c|}
\hline--- & --- & -- & --- & --- & --- & -- & --- & $\begin{array}{l}\text { Robinson } \\
\text { (1959b, } \\
\text { p. } 560-566) \text {. }\end{array}$ \\
\hline--- & --- & --- & --- & --- & -- & --- & --- & $\begin{array}{l}\text { Brewer, p. } 725, \\
\text { in Robinson } \\
\quad(1964) .\end{array}$ \\
\hline--- & --- & --- & --- & --- & -- & --- & --- & Do. \\
\hline--- & --- & --- & --- & --- & --- & --- & --- & $\begin{array}{l}\text { Brewer, p. } 726 \text {, } \\
\text { in Robinson } \\
(1964) .\end{array}$ \\
\hline--- & --- & --- & --- & --- & --- & --- & -- & Do. \\
\hline--- & 4,286 & --- & --- & 6,596 & --- & 11,231 & -- & $\begin{array}{l}\text { Robinson and } \\
\text { Collins (1959 } \\
\text { p. 501-520). }\end{array}$ \\
\hline--- & --- & --- & -- & --- & --- & --- & --- & $\begin{array}{l}\text { Collins (1958c, } \\
\text { p. 353-371); } \\
\text { Reed (1958, } \\
\text { p. } 146) .\end{array}$ \\
\hline-- & --- & --- & --- & --- & --- & --- & --- & $\begin{array}{l}\text { Collins (1961) } \\
\text { P. 575-582); } \\
\text { MacCarthy } \\
\text { (1962) }\end{array}$ \\
\hline-- & --- & -- & -- & 1,600 & --- & -- & --- & $\begin{array}{l}\text { Collins (1959, } \\
\text { p. 424-446). }\end{array}$ \\
\hline
\end{tabular}
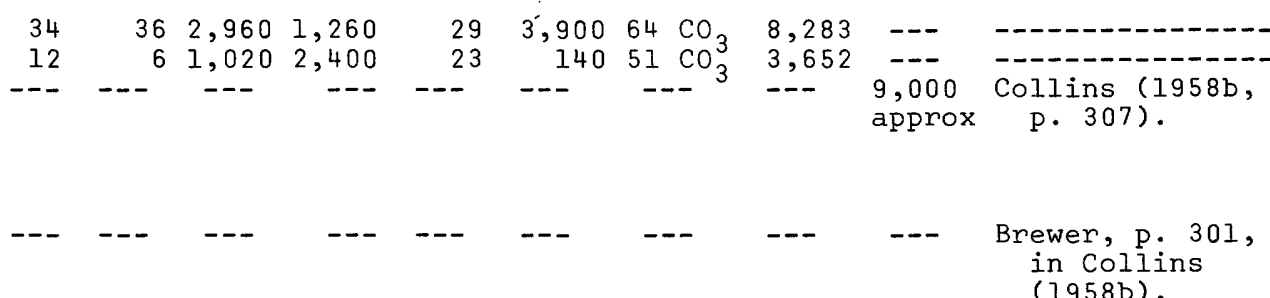

in Collins 


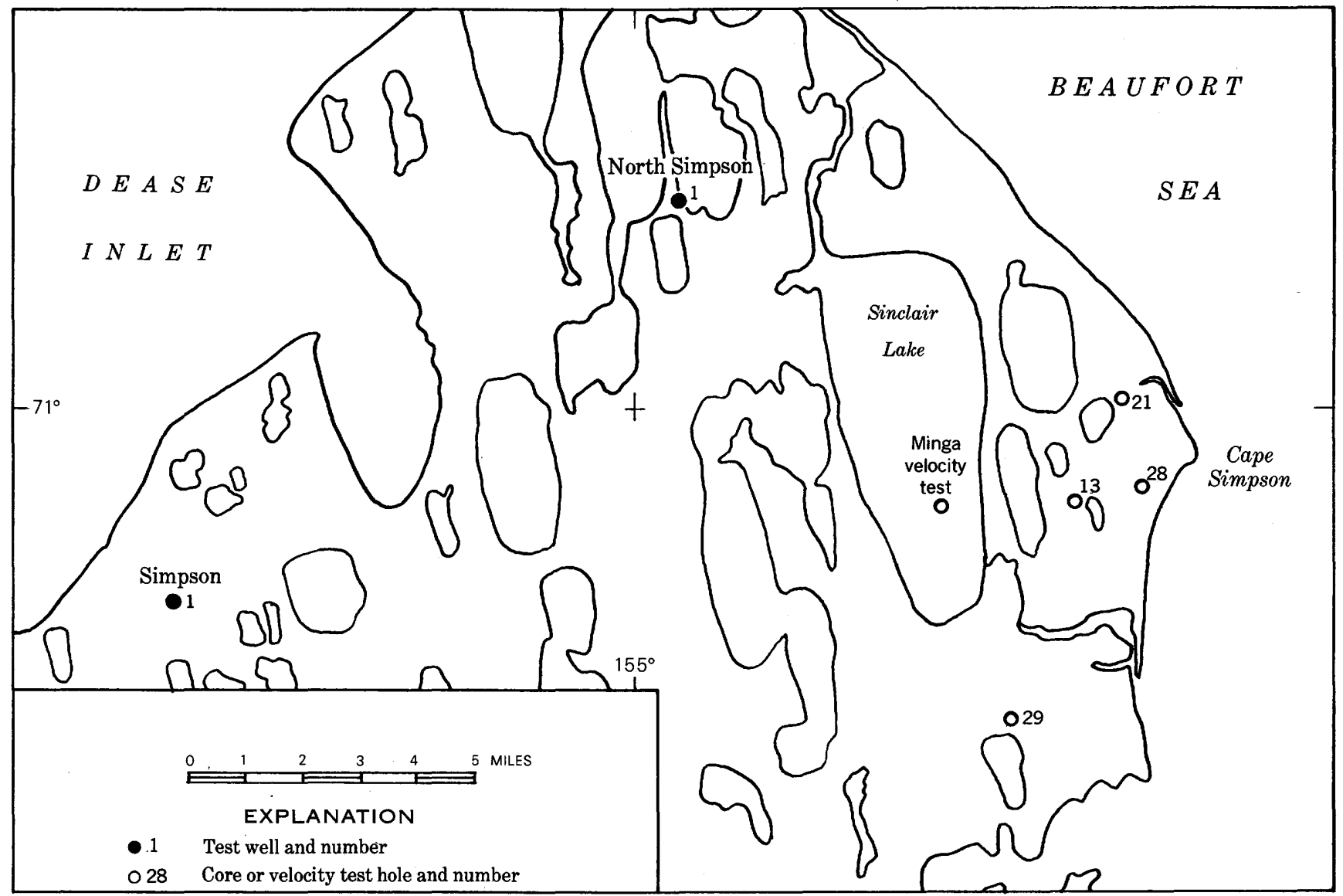

FIGURE 24.-Location of test wells and test holes, Cape Simpson area.

Suprapermafrost ground water in unfrozen coastal plain deposits and bedrock beneath surface water is available throughout the year if the permafrost table is below the maximum depth of winter freezing and the deposits have sufficient volume and permeability. Suprapermafrost ground water beneath lakes within 5 miles of the Arctic coast may be recharged from brackish or saline lakes, but lakes more than 5 miles from the coast are generally fresh (Brewer, $1958 \mathrm{~b}$, p. 26). Ground water in the sediments directly beneath fresh-water lakes is probably potable; the fresh ground water may be underlain by saline or brackish water. Whether fresh or saline, supplies are limited by the scarcity of unfrozen permeable unconsolidated deposits and bedrock and by the small volume available for storage beneath all but the largest lakes and rivers.

\section{COASTAL PLAIN AT NOME}

The stratigraphy of the coastal plain at Nome is complex (fig. 25) (Hopkins and others, 1960). The surficial deposits of the coastal plain are largely till of the Nome River Glaciation. This till overlies: (1) Beach and associated marine sediments of the Third and Intermediate Beaches, (2) till of the Iron Creek Glaciation, (3) marine sediments of the Fourth Beach, and (4) marine sediments of the Submarine Beach. The Nome River till is mantled locally by: (1) Marine sand and gravel and associated estuarine sandy silt of the Second Beach, (2) outwash and alluvial-fan gravel of the Salmon Lake Glaciation (Wisconsin), (3) peat, loess, and colluvium of Pleistocene and Holocene age, and (4) alluvium and beach deposits of Holocene age (fig. 25).

The ground is generally frozen from the surface into bedrock that lies at a depth of 40 to 80 feet (fig. 25, $A-A^{\prime}$ ). The maximum thickness of frozen ground observed in prospect and mine shafts is given as 90 feet (Moffit, 1905), greater than 100 feet (Hess, 1906), and greater than 120 feet (Brooks, 1906, p. 45). No relation was noted by Smith $(1909$, p. 271$)$ between the occurrence of unfrozen zones and the topography in the areas being mined then by underground methods. Taber 
(1943, p. 1510) and Hopkins (in Hopkins and others, 1955) reported that unfrozen zones are found along the base of the bedrock hills that border the coastal plain on the north (fig. 25) ; these unfrozen zones are places where water percolates from the hills into the coastal-plain deposits. Unfrozen ground in some of the buried beach deposits resting on bedrock is attributed to circulation of ground water and the unfrozen ground may lie between layers of frozen ground (Moffit, 1907, p. 136). However, Gibson (1914) noted that where deposits of the buried Third Beach were undisturbed, the ground was frozen from near the surface to bedrock; where the beach deposits had been reworked by streams before the Nome River Glaciation, the ground was unfrozen. Deposits beneath Snake River are unfrozen to a depth of at least 30 feet, well below the depth of seasonal freezing (Ste-
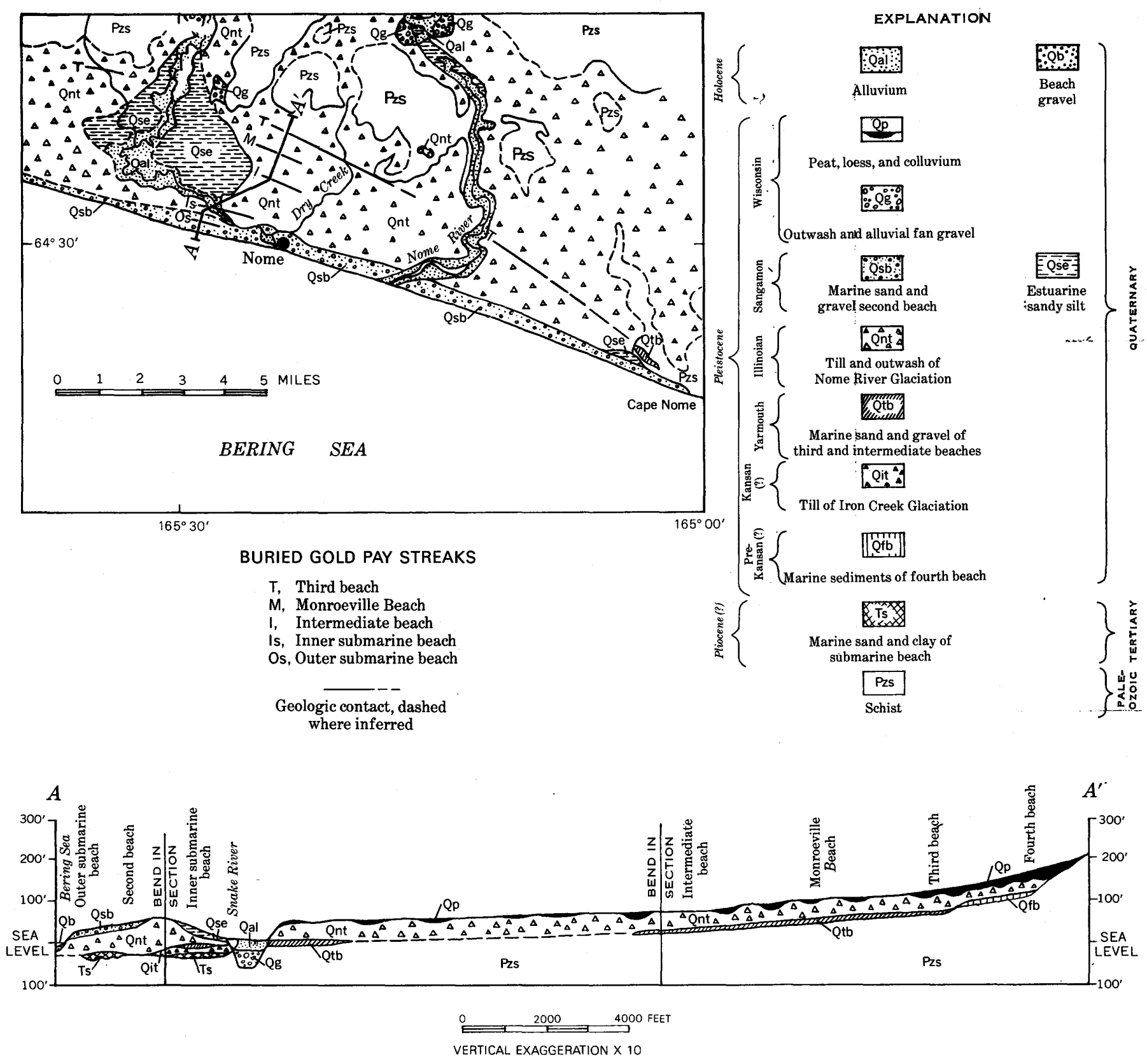

Figure 25.-Generalized geology of the coastal plain at Nome. 
fansson, 1910). Permafrost is still forming in the Nome area, because, since 1942, mine tailings have become frozen to bedrock 60 feet below land surface (Kellogg and Nygard, 1951; Sigafoos, 1951).

Water for Nome is obtained from wells and springs (Cederstrom, 1952, p. 33-34; Lohr, 1957; Waller and Mathur, 1962). Wells on the seaward edge of the coastal plain have produced brackish water, but springs along the hills north of the city and shafts in some of the buried beach deposits have yielded potable water. Wells in the city, which is built on deposits of the Second Beach (fig. 25), are from 8 to 70 feet deep (Waller and Mathur, 1962). The deepest well reached brackish water at an altitude of 5.5 feet above sea level. At the airport, constructed on placer tailings, wells 35-45 feet deep yield potable water, but at least one yields water having $3,600 \mathrm{mg} / 1$ chloride (Cederstrom, 1952 , p. 33). The main source of water is Moonlight Springs, near the base of the hills at the northern edge of the coastal plain; the flow from these springs is about $300 \mathrm{gpm}$ of water having a temperature of $2.7^{\circ} \mathrm{C}$. Subpermafrost artesian water is available from local unfrozen zones in the deposits of buried beaches. During drift mining of the beach deposits, a shaft on Bourbon Creek in the coastal plain north of Nome intercepted unfrozen gravel. Water under pressure flooded the shaft and adjacent workings (Gibson, 1914). The initial height of the column of water issuing from the headframe of the shaft was reported to be 70 feet above land surface (Mining and Scientific Press, 1909, p. 315). Permafrost reportedly deters the development of wells near the waterfront in the city. Available data on permafrost in city and inland wells are insufficient to map the distribution and thickness of permafrost and the brackish water-fresh water boundary. However Cederstrom (1952, p. 34) suggested that potable water may be available from permeable, unfrozen alluvium beneath the bed of Dry Creek.

\section{BRISTOL BAY AND COOK INLET LOWLANDS}

Unconsolidated deposits in the coastal lowland bordering Bristol Bay consist of till interbedded with sand, silt, and gravel of fluvial and marine origin. Away from the rivers, the deposits are frozen to a maximum reported depth of 175 feet, but permafrost occurs in only a quarter of about 600 wells and borings, most of which were drilled along the north shore of Kvichak Bay east of Nushagak (fig. 7). Most producing wells drilled through permafrost obtain water from sand and gravel that is interbedded with the glacial deposits.

The stratigraphy of the Cook Inlet lowland is similar to that of the Bristol Bay lowland, but includes glaciolacustrine deposits (Miller and Dobrovolny, 1959 ; Karlstrom, 1954). The deepest known permafrost in the lowland extends 33 feet below land surface near Anchorage. The permafrost is localized beneath muskegs, on shaded slopes, and in valleys; it is of such limited extent and thickness that it is rather insignificant, even locally, in controlling recharge, discharge, movement, and storage of ground water.

\section{BEDROCK OF UPLANDS AND MOUNTAINS DISTRIBUTION AND THICKNESS OF PERMAFROST}

Distribution of permafrost in mountain and upland bedrock is subject not only to the regional zonation of permafrost (fig. 1), but also to local variations caused by topographic, climatic, vegetative, hydrologic, and geologic differences. In the continuous-permafrost zone, the few wells drilled in the Arctic Foothills and near Cape Thompson show that permafrost is generally between 700 and 1,170 feet thick. In the discontinuous-permafrost zone, using data from both Canada and Alaska, two general categories of permafrost distribution are apparent: (1) High mountains and hills, generally more than 3,000 feet above sea level, in which permafrost decreases in thickness downslope and (2) lowerhills, generally below 3,000 feet in altitude, in which permafrost is thin or absent near the summit but increases in thickness downslope. The meager data on ground water in bedrock is summarized below for the continuous-and discontinuous-permafrost zones.

\section{CONTINUOUS-PERMAFROST ZONE} ARTIC FOOTNOTES

The Arctic Foothills, between the Brooks Range and the Arctic Coastal Plain (fig. 2), are composed of sandstone, shale, and siltstone of Mesozoic age (Payne, and others, 1952). The rocks are folded in a series of echelon east-west trending anticlines and synclines which are cut locally by faults. Some test wells were drilled through 750 to 1,055 feet of permafrost during exploration for oil in Naval Petroleum Reserve No. 4 (table 4 ; figs. 2 and 11). In other test wells, the depth to the base of permafrost was not determined. Recharge from the surface to the subpermafrost aquifers and discharge from the aquifers to the surface is prevented by permafrost and by impermeable boundaries within the bedrock. The data (table 4) show that only small quantities 
of brackish or saline water are available below the permafrost.

\section{BROOKS RANGE}

The Brooks Range is composed of rock units that trend east west. These units consist of: (1) Metasedimentary rocks of Paleozoic age in the southern part of the range, (2) sedimentary rocks of Paleozoic age in the central part, and (3) a belt of sedimentary rocks of Paleozoic age that thrust over sedimentary rocks of Mesozoic age in the northern part of the range (Payne and others, 1952).

Permafrost in the Brooks Range is known only from placer-mine shafts in unconsolidated deposits where it is more than 365 feet thick near the southern boundary of the continuous-permafrost zone and from test holes in the Cape Thompson area where it is 945-1,170 feet thick in siltstone of Mesozoic age (Lachenbruch and others, 1961, fig. 11). No records are available of the distribution of permafrost in bedrock nor of the existence of unfrozen zones that perforate permafrost.

Ground water in the eastern Brooks Range is known only from springs (fig. 5) that are associated with faults in limestone of the Lisburne Group of Mississippian and Pennsylvanian age or with faults that separate the limestone from other kinds of rocks (Waring, 1917, p. 95; Leffingwell, 1919, p. 58-59; Hopkins and others, 1955 p. 119; Spetzman, 1959 , p. 23; C. R. Lewis, 1962, and written commun., March 1963; M. D. Mangus, oral commun., 1964). The springs are perennial and form large icings that occupy segments of some major valleys of the Brooks Range east of $149^{\circ}$ west longitude. Large icings in valleys in which springs have not yet been reported show that springs may exist, especially if faults involving the limestone are near the upper end of the icings.

The largest known springs in the eastern Brooks Range (fig. 5) are the Shublik Springs which have a perennial flow of about $1,000 \mathrm{gpm}$ at a temperature reported as $6^{\circ} \mathrm{C}$ by Leffingwell (1919) and $11^{\circ} \mathrm{C}$ by Mangus (oral commun., 1964). The flow downstream from the springs was reported to be so great that the creek could not be crossed on foot (Leffingwell, 1919, p. 59). The Sadlerochit Springs have an estimated discharge of about $500 \mathrm{gpm}$ (C. R. Lewis, written commun., 1963) and a temperature of $11^{\circ} \mathrm{C}$ (M.D. Mangus, oral commun., 1964). Both springs are on reverse faults along which the limestone of the Lisburne Group is brought into contact with the Sadlerochit Formation of Permian and Triassic age (M. D. Mangus, oral commun.,
1964). Springs on the divide between Ignek and Tamayariak Creeks, along the north flank of the Shublik Mountains (fig. 5), issue from a highangle reverse fault in which the limestone is brought into contact with rocks of Cretaceous age (M. D. Mangus, oral commun., 1964). Springs on the Ivishak, Echooka, Sheenjek, and Canning Rivers (fig. 5), according to Mangus, also issue from faults involving the limestone. Although located at the toe of an alluvial fan, Tulugak Springs in Anaktuvuk Pass (central Brooks Range) (Spetzman, 1959, fig. 8), may originate in limestone exposed in the valley wall to the east or at its contact with other rocks.

Springs in the western Brooks Range issue from sea cliffs between Cape Thompson and the Igichuk Hills, 100 miles southeast (Waller, 1960a, b), and at Cape Lisburne (fig. 3). The principal spring is Kavrorak Spring, near Cape Seppings, which issues from the base of a thick, high limestone cliff of the Lisburne Group that is several tens of feet above sea level (Piper, 1961, p. 21). Other springs issue from limestone talus at the base of cliffs along lower Nasorak Creek near Cape Thompson (Piper, 1961 , p. 23). Springs in the Igichuk Hills have been sampled (Waller, 1960b), but those in the limestone cliffs at Cape Lisburne have not.

The discharge of Kavrorak Spring varies from 4 cfs $(1,800 \mathrm{gpm})$ in winter to $53 \mathrm{cfs}(24,000 \mathrm{gpm})$ in summer; the temperature varies from $4^{\circ}$ to $5^{\circ} \mathrm{C}$; and the concentration of dissolved solids, unlike most springs, varies directly with discharge (Waller, 1960a, b; 1961b). According to Waller, part of the water discharged from Kavrorak Spring and from those along Nasorak Creek may enter fractures and faults in the bedrock beneath unfrozen alluvium under the Kukpuk River and may be mixed with local water as it emerges from springs, after passing through or under permafrost for a distance of at least 3 miles. Piper (1961, p. 22) said that the variations in flow suggest a local, rather than distant, source and that if the conduit through which the water moved were a cavernous zone in the limestone that extended to such a remote area, the springs would have more uniform discharge. The variable content of dissolved solids is explained by mixing of the spring water with sea water, since the samples were taken from creeks crossing beach deposits, and not from the spring orifices in bedrock (Piper, 1961, p. 22).

Central Seward Peninsula, near the boundary between the discontinuous- and continuous-permafrost zones, is an area of mountains, uplands, lava plateaus, and alluvial valleys. Schist, gneiss, and 
TABLE 4.-Data on permafrost and ground water

\begin{tabular}{|c|c|c|c|c|}
\hline $\begin{array}{l}\text { Name, type } \\
\text { and location } \\
\text { of well }\end{array}$ & $\begin{array}{l}\text { Total } \\
\text { depth } \\
\text { (feet) }\end{array}$ & $\begin{array}{l}\text { Depth to } \\
\text { base of } \\
\text { permafrost } \\
\quad(\text { feet) }\end{array}$ & $\begin{array}{l}\text { Temperature } \\
\text { of perma- } \\
\text { frost o } \\
\text { at depth } \\
\text { (feet) }\end{array}$ & $\begin{array}{l}\text { Ground-water occurrence } \\
\text { and yield; results of } \\
\text { formation tests }\end{array}$ \\
\hline $\begin{array}{l}\text { Umiat area, } \\
\text { fig } 13:\end{array}$ & & & & $\cdot$ \\
\hline $\begin{array}{l}\text { Umiat test } \\
\text { well } 1 .\end{array}$ & 6,005 & 920 & ------ & $\begin{array}{l}\text { Drilling mud cut with } \\
\text { fresh water; yield } \\
\text { approx } 9 \text { gpm at } \\
\text { 1,693-1,816 ft. }\end{array}$ \\
\hline $\begin{array}{l}\text { Umiat test } \\
\text { well } 4 .\end{array}$ & 840 & 897 & $-6.20 \quad 100$ & --- - - - \\
\hline $\begin{array}{l}\text { Umiat test } \\
\text { well } 8 \text {. }\end{array}$ & 1,327 & $535+$ & $-\cdots--$ & 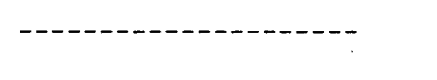 \\
\hline $\begin{array}{l}\text { Umiat test } \\
\text { well } 9 .\end{array}$ & 1,257 & 1,055 & -7.2 & 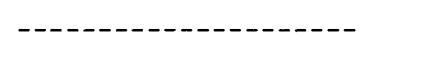 \\
\hline $\begin{array}{l}\text { Umiat test } \\
\text { well } 11 .\end{array}$ & 3,303 & $\begin{array}{r}770 \\
\text { approx }\end{array}$ & \multirow[t]{2}{*}{------} & $\begin{array}{l}\text { Brackish water recovered } \\
\text { in formation tests. } \\
950 \mathrm{ft} \text { water in test } \\
\text { at } 2,094.5-2,145 \mathrm{ft} .\end{array}$ \\
\hline & & & & $\begin{array}{l}1,027 \mathrm{ft} \text { recovered in } \\
\text { test at } 2,375-2,411 \\
\mathrm{ft} . \\
1,304 \mathrm{ft} \text { recovered in } \\
\text { test at } 2,447-2,461 \\
\mathrm{ft} \text {. } \\
1,944 \mathrm{ft} \text { recovered in } \\
\text { test at } 2,814-2,830 \\
\mathrm{ft} . \\
2,285 \mathrm{ft} \text { recovered in } \\
\text { test at } 2,832-2,850 \\
\text { ft. } \\
\text { (Driling mud salinity } \\
\text { was } 225 \text { to } 450 \mathrm{mg} / 1 \\
\text { in all tests.) }\end{array}$ \\
\hline $\begin{array}{l}\text { Other areas, } \\
\text { fig } 4:\end{array}$ & & & & \\
\hline $\begin{array}{l}\text { Grandstand } \\
\text { test } \\
\text { well } 1 .\end{array}$ & 3,939 & --- & ------ & $\begin{array}{l}\text { Sample largely drilling } \\
\text { mud from 865-899. }\end{array}$ \\
\hline $\begin{array}{l}\text { Gubik test } \\
\text { well } 2 \text {. }\end{array}$ & 4,620 & --- & $-\cdots---$ & $\begin{array}{l}\text { Formation test 1,928- } \\
\text { 1,984. } \\
\text { Test of gas sand } 3,781- \\
\text { 3,903 (Salinity drill- } \\
\text { ing mud, } 400 \mathrm{mg} / 1 . \text { ) }\end{array}$ \\
\hline $\begin{array}{l}\text { Knifeblade } \\
\text { test } \\
\text { well } 1 .\end{array}$ & 1,805 & 882 & $-\cdots--$ & $\begin{array}{l}\text { Water at base of perma- } \\
\text { frost; water rose to } \\
375 \mathrm{ft} \text {. } \\
\text { At } 1,250 \mathrm{ft} \mathrm{(rate} \mathrm{of} \\
\text { entry } 15-1 / 2 \mathrm{gpm} \text { ). } \\
\text { At } 1,373 \mathrm{ft} \text { (rate of } \\
\text { entry } 1 \mathrm{gpm} \text { ). }\end{array}$ \\
\hline $\begin{array}{l}\text { Knifeblade } \\
\text { test } \\
\text { well } 2 \mathrm{~A} .\end{array}$ & 1,805 & 758 & ----- & $\begin{array}{l}\text { Water at base of perma- } \\
\text { frost. } \\
\text { Water at } 1,805 \mathrm{ft}\end{array}$ \\
\hline $\begin{array}{l}\text { East Ouma- } \\
\text { lik test } \\
\text { well } 1 .\end{array}$ & 6,035 & $750+$ & $-\cdots--$ & 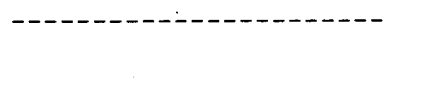 \\
\hline $\begin{array}{l}\text { Titaluk test } \\
\text { well l. }\end{array}$ & 4,020 & $800+$ & \multirow{2}{*}{-----} & - - - \\
\hline $\begin{array}{l}\text { Wolf Creek } \\
\text { test } \\
\text { well } 2\end{array}$ & 1,618 & $-\cdots$ & & $\begin{array}{l}\text { Fonftation test } 940-960 \mathrm{ft} \text {; } \\
\mathrm{ft} \text {; yield } 20 \mathrm{gph} .\end{array}$ \\
\hline
\end{tabular}

\footnotetext{
${ }^{1}$ Analyses by U.S. Bur. Mines.
} 
in the Arctic Foothills of the Brooks Range

\begin{tabular}{|c|c|c|c|c|c|c|c|c|c|}
\hline $\mathrm{Ca}$ & $\mathrm{Mg}$ & $\mathrm{Na}$ & $\mathrm{HCO}_{3}$ & $\mathrm{SO}_{4}$ & $\mathrm{Cl}$ & other & Total & Salinity & $\begin{array}{l}\text { Sources of in- } \\
\text { formation for } \\
\text { quality of } \\
\text { water }\end{array}$ \\
\hline--- & --- & --- & --- & -- & --- & ---- & ---- & ------ & $\begin{array}{l}\text { Collins (1958a, } \\
\text { p. } 95 \text { and 99). }\end{array}$ \\
\hline-- & --- & --- & --- & -- & -- & $-\cdots$ & ---- & ------ & $\begin{array}{l}\text { Brewer, p. 131- } \\
\text { l32 in Collins } \\
\text { (1958a). }\end{array}$ \\
\hline--- & --- & -- & -- & --- & --- & ---- & --- & ---- & $\begin{array}{c}\text { Collins (1958a, } \\
\text { p. 149-153). }\end{array}$ \\
\hline-- & --- & --- & --- & --- & --- & --- & --- & ----- & $\begin{array}{l}\text { Brewer, } \mathrm{p} \text {. 170- } \\
\quad 171 \text { in Collins } \\
\text { (1958a). }\end{array}$ \\
\hline 42 & 5 & --- & --- & 42 & --- & ---- & ---- & 4,290 & $\begin{array}{l}\text { Brewer, p: } 197, \\
\text { in Collins } \\
\text { (1958a); } \\
\text { Collins (1958a, } \\
\text { p. 193-194). }\end{array}$ \\
\hline 30 & 9 & 2,190 & 2,960 & 21 & 1,600 & $\mathrm{CO}_{3}$ & 6,906 & 1,550 & \\
\hline 8 & 3 & 2,030 & 3,120 & 28 & 865 & $\begin{array}{l}390 \\
\mathrm{CO}_{3}\end{array}$ & 6,434 & 2,723 & \\
\hline--- & --- & --- & --- & --- & --- & --- & --- & 3,340 & \\
\hline 14 & 4 & 2,190 & 2,240 & 19 & 1,950 & $\begin{array}{l}126 \\
. \mathrm{CO}_{3}\end{array}$ & 6,543 & 3,300 & \\
\hline
\end{tabular}

\begin{tabular}{|c|c|c|c|c|c|c|c|c|c|}
\hline 56 & 35 & 244 & -- & 17 & 446 & --- & -- & ----- & $\begin{array}{c}\text { Robinson (1958a, } \\
\text { p. } 317-336) .\end{array}$ \\
\hline-- & --- & -- & --- & --- & --- & --- & --- & 2,475 & $\begin{array}{l}\text { Robinson (1958b, } \\
\text { p. } 253-254) .\end{array}$ \\
\hline--- & -- & --- & --- & --- & --- & --- & --- & 7,755 & \\
\hline-- & --- & --- & --- & --- & --- & --- & --- & 5,000 & $\begin{array}{l}\text { Robinson (1959b, } \\
\text { p. } 397-416) .\end{array}$ \\
\hline--- & -- & -- & -- & -- & --- & $-\ldots$ & --- & 4,000 & \\
\hline-- & $-\ldots$ & --- & --- & --- & --- & --- & --- & 6,380 & \\
\hline--- & --- & --- & --- & -- & --- & --- & --- & 4,500 & Robinson (1959b, \\
\hline-- & --- & --- & --- & --- & --- & --- & ---- & $\begin{array}{l}4,000- \\
5,000\end{array}$ & p. $397-416)$ \\
\hline--- & --- & --- & -- & --- & --- & --- & --- & ------ & $\begin{array}{l}\text { Robinson (1956, } \\
\text { p. } 51-63) .\end{array}$ \\
\hline--- & --- & $-\cdots$ & --- & --- & --- & --- & --- & ---- & $\begin{array}{c}\text { Robinson (1959b, } \\
\text { P. 381-397). }\end{array}$ \\
\hline-- & --- & --- & -- & --- & 9,405 & ---- & --- & ----- & $\begin{array}{l}\text { Collins (1959, } \\
\text { p. 453-457). }\end{array}$ \\
\hline
\end{tabular}


metalimestone of Paleozoic age are intruded by stocks and smaller masses of granitic rocks of Mesozoic age (Hopkins, 1963, p. C1). The older rocks are overlain by the Kougarok Gravel of late Tertiary and Pleistocene(?) age and by volcanic rocks of late Cenozoic age (Hopkins, 1963). Glacial drift and eolian, lacustrine, and alluvial deposits of Pleistocene age mantle the older rocks.

Permafrost is present nearly everywhere in the central Seward Peninsula and reaches a maximum recorded thickness of 200 feet (Hopkins, in Hopkins and others, 1955, p. 121). Irregular local configuration of permafrost is shown by subterranean drainage of surface streams into the lava flows and metalimestone, and by springs that emerge from those rocks.

Ground-water hydrology in these deposits is complex and poorly understood. Hopkins (1963, p. C90-C93) summarized existing information on ground water in bedrock as follows. Springs issue from solution-enlarged joints in the metalimestone, especially at the downstream end of valleys crossing the metalimestone belt. At low flow some streams lose their entire discharge into the metalimestone, but regain surface flow at the point where the stream leaves the metalimestone and re-enters the schist belt. Surface water is recharged directly into large openings in the lava, or into blocky rubble in the surface of the younger volcanic flows and is discharged as springs. Some of the older flows, mantled by silt, have surface streams that terminate in thaw sinks (Hopkins, 1949), through which water percolates into the volcanic rocks. Ground water is discharged from the lava flows to the alluvial deposits in the valleys or by springs.

\section{DISCONTINUOUS-PERMAFROST ZONE}

Few data are available to show the relation between permafrost and ground water in upland and mountain bedrock of the discontinuous-permafrost zone. However, Cederstrom (1963) mentioned bedrock aquifers in the Fairbanks area. Elsewhere, isolated wells, groups of wells, and springs show that ground water is probably available in small quantities from bedrock aquifers beneath permafrost in most uplands and mountains.

YUKON-TANANA UPLAND NEAR FAIRBANKS

Bedrock of the upland near Fairbanks consists of schist and local beds of metamorphosed limestone that has been cut by stocks of granitic rocks. These rocks are overlain locally by continental sedimentary rocks and lava flows of Cenozoic age (Mertie,
1937). The bedrock is covered with unfrozen loess and weathered rock on the summits and upper slopes, and with frozen silt containing or overlying local channel deposits of sand and gravel on the lower slopes. Permafrost ranges in thickness from a few feet near its upper limit on the upper slopes to as much as 360 feet in some valleys. In many places permafrost extends into the bedrock.

Wells drilled in schist produce water from individual fractures and fracture zones containing abundant vein quartz and from quartzite members (Cederstrom, 1963, p. 32). Water is recharged to bedrock aquifers through unfrozen loess and weathered rock on hilltops and upper slopes, and from alluvial aquifers in the valleys and on lower slopes. The water table in bedrock near the summits of narrow ridges is as much as 490 feet deep, but flowing wells on some lower slopes are drilled through unfrozen silt, frozen silt and gravel, or frozen bedrock into confined bedrock aquifers. Water levels in wells in bedrock are determined largely by the rock structure and the geometry of the fracture systems. Cederstrom (1963, p. 28, fig. 6) noted that the potentiometric surface of the confined aquifers in bedrock apparently flattens above the upper limit of permafrost on hillsides and that the water level in water-table wells in bedrock above the upper limit of permafrost is apparently related to the height to which permafrost extends upslope. However, flowing and nonflowing artesian wells in bedrock occur above the upper limit of permafrost.

ALASKA RANGE

Permafrost was not logged in four wells in schist at McKinley Park station (figs. 7, 8), but was present to a depth of about 190 feet in a well in schist at Wonder Lake in Mount McKinley National Park. Near Windy (fig. 8), south of McKinley Park station, large springs issue from a major fault separating graywacke and shale of Paleozoic age from rocks of Mesozoic age (Rutledge and others, 1953). Near the head of Soda Creek in the Mentasta Mountains (fig. 8), in the eastern part of the Alaska Range, springs are found along a fault between lava flows and limestone of Permian age and shale of Mesozoic age (Moffit, 1941, p. 131. pl. 6A). Springs from limestone have been used as source of water for mining operations at White Mountain, near Nabesna. Scattered data show that permafrost occurs in the Alaska Range, but that numerous unfrozen zones are available for recharge and discharge of ground water. 
TALKEETNA MOUNTAINS

Scattered occurrences of permafrost have been noted (Capps, 1940) above an altitude of 3,000 feet in the western Talkeetna Mountains, particularly in the lode gold mines of the Willow district (Capps, 1914; Ray, 1954). Test borings recorded permafrost at the V-damsite on Susitna River in the northeastern Talkeetna Mountains (fig. 8). However, no data are available on the effect of permafrost on ground-water occurrence in this largely unpopulated region.

\section{CHUGACH-KENAI MOUNTAINS}

Frozen ground has not yet been reported in bedrock of the Chugach Range, but has been noted at high elevations in unconsolidated deposits near Girdwood (Smith, 1934) and at low elevations on slopes near Anchorage (Karlstrom, 1964). The only large construction project in bedrock of the Chugach Range has been the Eklutna dam and tunnel near Anchorage. The tunnel, driven from Glenn Highway 4 miles south to Eklutna Lake, produced very large flows of water from fractures and faults and reportedly did not pass through frozen rock.

Frozen ground has not been reported in drill holes and mining excavations in the Kenai Mountain valleys, but, as in the Chugach Range to the north, practically nothing is known about conditions in bedrock at the higher elevations. Mountain ranges in western Canada have isolated bodies of permafrost at high elevations; thus, similar bodies of permafrost may eventually be found in the Kenai Mountains, and perhaps also in the mountain ranges of Kodiak Island and southeastern Alaska.

WRANGELL MOUNTAINS

Frozen ground is reported to depths of 500-600 feet (Bateman and McLaughlin, 1920) in workings of the Bonanza copper mine near Kennicott, where underground air temperatures ranged from $0^{\circ} \mathrm{C}$ to $-1.1^{\circ} \mathrm{C}$. The mine is high on the steep slopes of a serrated 5,500-foot ridge. Elsewhere in the Kennicott mining district, frozen talus was reported at an elevation of 1,400 feet in the Kotsina River draingage (Moffit and Maddren, 1908), and frozen gravel was noted by Moffit (1912) in placer mine workings in the Chititu Creek basin.

OTHER UPLANDS OF INTERIOR ALASKA

Wells in the Yukon-Tanana Upland near Northway (fig. 8) either have been drilled in unfrozen unconsolidated deposits and bedrock or have developed water, chiefly from granitic rocks beneath per- mafrost. In the wells drilled through permafrost into bedrock, water was confined beneath the permafrost or had a static level or water table that was below the recorded base of frozen ground.

At Ruby (fig. 4) on the Yukon River, three wells about 70 feet deep produce water from unfrozen metamorphosed limestone, and, to the north at Indian Mountain, a deep hole drilled in unfrozen metavolcanic rocks produced copious supplies of water from a fracture zone.

ISOLATED HILLS AND UPLANDS IN THE COASTAL LOWLAAND OF WESTERN ALASKA

Scattered subsurface data available from hills within and bordering the Yukon-Kuskokwim delta show that water circulates locally through the bedrock and may be found beneath permafrost. A well at Cape Romanzof was reportedly drilled 162 feet in unfrozen blocky talus and bedrock beneath a cirque floor. In the St. Michael area, large freshwater springs issue from openings in volcanic flows on the mainland about 2 miles northeast of the town (fig. 6) (Dall, 1870; Cederstrom, 1952, p. 32). A well drilled in the village of St. Michael passed through 203 feet of frozen interbedded clay and lava and reached a saline aquifer in unfrozen sand between 203 and 247 feet.

\section{QUALITY OF WATER}

Ground water in the permafrost regions of Alaska is generally either of the calcium bicarbonate or of the sodium chloride type. Although no special study of the chemical quality of ground water has been undertaken in the present investigation, the quality in permafrost regions apparently depends on the same reactions between ground water and enclosing rocks that take place in temperate regions. The general restriction of groundwater circulation and recharge by permafrost may provide a longer time for chemical reactions to take place.

Calcium bicarbonate water and its local variant, sodium bicarbonate water, is common in alluvium and other unconsolidated deposits and in metamorphic rocks. In unconsolidated deposits that include lenses and beds of organic material or finely disseminated organic particles, the water may have objectionable concentrations of iron and manganese, high hardness, and a high degree of color. Flammable gas, chiefly methane, confined beneath the permafrost or within the sediments, is associated with ground water in unconsolidated deposits and with 
poorly consolidated sedimentary rocks that have a high organic content in some interior valleys and coastal lowlands.

Saline water, principally sodium chloride, is common in unconsolidated deposits near the coast and in marine sedimentary rocks of Mesozoic age beneath the Arctic Coastal Plain and the Arctic Foothills. Two types of water are recognized in the Copper River Lowland (Grantz and others, 1962, p. 1992): the $\mathrm{Na}-\mathrm{Ca}-\mathrm{Cl}$ waters chiefly west of the Copper River, and the $\mathrm{Na}-\mathrm{Cl}-\mathrm{HCO}_{3}$ waters of springs on the west slopes of Mount Drum, a late Cenozoic volcano. The $\mathrm{Na}-\mathrm{Cl}-\mathrm{HCO}_{3}$ water was probably formed by modification of the $\mathrm{Na}-\mathrm{Ca}-\mathrm{Cl}$ water by adding volcanic water, metamorphic water, or $\mathrm{CO}_{2}$ from volcanic or sedimentary rocks.

Seasonal changes occur in the concentration of the dissolved solids of ground water in shallow aquifers within and below the zone of seasonal freezing. These changes have been attributed to the lack of dilution by less mineralized surface water during winter and to the concentration of this water by freezing of the upper part of the aquifers during winter (Waller, 1962; Feulner and Schupp, 1963). The quality of subpermafrost water is normally stable throughout the year.

Bacterial pollution and contamination by fuel oil and animal wastes are most common in shallow wells that obtain water from aquifers above the permafrost, such as those at Kotzebue and Fairbanks. The few known cases of contamination of subpermafrost water were caused by carelessness in disposal of sewage and petroleum products near wells, or by improper well construction.

Temperature of ground water is an especially important factor in designing water systems. Temperature data are needed to determine whether regular pumping or artificial heating of wells is required to prevent freezing of the water rising under static head in the casing within the permafrost zone. Data are also needed to determine whether heating well water is necessary before distributing the water through mains buried in permafrost, through mains within the zone of seasonal freezing, or in surface lines exposed to cold air.

In the permafrost regions of Alaska, the temperature of potable well water ranges from $0^{\circ}$ to $4.5^{\circ} \mathrm{C}$. It averages $1.7^{\circ} \mathrm{C}$ at Fairbanks and $2.8^{\circ} \mathrm{C}$ at Anchorage, near the southern limit of permafrost. These figures are based on fewer than 150 measurements made without knowledge of: (1) The effect of pumping on the thermal regimen of the ground surrounding the casing, (2) the presence or absence of permafrost, (3) the duration of pumping before temperature measurement, (4) the variations in seasonal temperature in the upper 50 feet of the ground, (5) artificial heating of wells, and (6) errors in instruments. Despite the potential for error, the results seem consistent with the few controlled experiments to determine ground-water temperature.

Temperature measurements were made in 1945 by Black and Veatch, Consulting Engineers, Kansas City, in two tests wells south of Fairbanks (fig. 14). In well 1, the casing was perforated, the well was pumped at $1,000 \mathrm{gpm}$, and the temperature was measured opposite each of four successively lower zones in the unfrozen alluvium below 70 feet, the base of permafrost. The results are as follows :

\begin{tabular}{ccc}
\hline $\begin{array}{c}\text { Depth of aquifer } \\
\text { tested } \\
\text { (feet) }\end{array}$ & $\begin{array}{c}\text { Depth below base of } \\
\text { permafrost } \\
\text { (feet) }\end{array}$ & $\begin{array}{c}\text { Temperature } \\
{ }^{\circ} \mathrm{C}\end{array}$ \\
\hline $76-86$ & $6-16$ & 0.6 \\
$118-125$ & $48-55$ & 1.1 \\
$218-228$ & $148-158$ & 1.7 \\
290 & 220 & 2.8 \\
\hline
\end{tabular}

In nearby test well 2 , drilled entirely in unfrozen alluvium, ground-water temperature increased from $1.1^{\circ} \mathrm{C}$ at 65 feet to $2.2^{\circ} \mathrm{C}$ at $202-206$ feet. Similar tests at Fort Wainwright, by U.S. Army Engineer District Alaska, showed that at the base of permafrost, 82 feet below land surface, the water temperature in unfrozen alluvium was $0.3^{\circ} \mathrm{C}$, but that it was $1.3^{\circ} \mathrm{C}$ in the aquifer 170 to 205 feet deep. These tests show that ground-water temperature increases with depth, as would be expected, and that it is probably consistent with the geothermal gradient of the enclosing alluvium until the temperature field is disturbed by pumping.

The temperature tests near Fairbanks show that the difficulties caused by water freezing in well casings in permafrost can often be avoided by drilling wells deep enough below the base of permafrost to obtain warmer ground water from the lower part of the aquifer. Thus, the expense of heating wells artificially may be eliminated. In addition, the costs of predistribution heating of the water may be eliminated or reduced.

The temperature of ground water in aquifers, less than 50 feet below land surface, has a seasonal range that varies with proximity to sources of summer recharge by warm surface water and with the thickness of the zone of winter freezing. The amplitude of seasonal temperature variations diminishes with depth, and the variations are out of phase in time with air temperatures; for example, 
at Barrow the maximum ground temperature at a depth of 30 feet lags behind maximum air temperature by 5 months (Brewer, 1958b, p. 20-22, fig. 3).

Springs are classified as: hot springs $\left(37^{\circ}-100^{\circ} \mathrm{C}\right)$, warm and cool springs $\left(0^{\circ}-37^{\circ} \mathrm{C}\right)$, and saline springs (generally less than $30^{\circ} \mathrm{C}$ ). The hot springs are of local economic importance in supplying heat for buildings and in providing warm water for irrigation of gardens. Hot springs are limited to the area south of the Brooks Range. Known springs of the continuous-permafrost zone north of the Brooks Range range in temperature from $0^{\circ}$ to $11^{\circ} \mathrm{C}$.

\section{CONCLUSIONS}

The presence of permafrost creates impermeable barriers to the recharge, movement, and discharge of ground water and to the mingling of waters of different chemical characteristics. Its presence also limits the volume of unconsolidated deposits and bedrock in which water can be stored. In some coastal environments, however, permafrost barriers protect suprapermafrost aquifers from sea-water intrusion.

The effect of permafrost upon ground-water occurrence depends on its local configuration. Its configuration depends largely on local differences in mean annual ground-surface temperature caused by topographic, vegetative, climatic, geologic, and hydrologic conditions and their variation over the last hundreds or thousands of years. The relation between configuration of permafrost and present ground-surface temperature is further complicated by the existence of relict permafrost that is out of thermal equilibrium with present ground-surface temperature. Much of the relict permafrost may have been inherited from the colder climate of Wisconsin time. The local configuration of permafrost, therefore, is largely dependent on the present, and to some extent on past thermal regimens, rather than on geologic environment, and generally does not coincide with geologic or landform boundaries. However, permafrost is commonly thicker beneath alluvial landforms of Wisconsin or older Pleistocene age than beneath those of Holocene age. An imperfect correspondence of local permafrost zones to landforms is noted in flood plains and low terraces of major valleys where landform development followed thaw of preexisting permafrost by a migrating river.

Application of the general principles stated above to geologic and hydrologic studies of ground-water resources may be an aid in locating sites where water may be present in unfrozen zones above permafrost, where permafrost may be thin, or where water may be recharged or discharged through unfrozen zones that perforate the permafrost. These principles have further application to problems involving creation of aquifers by thawing the frozen ground, such as was done in the alluvium of Selin Creek near Cape Lisburne.

The present study of ground water in permafrost regions, lacking quantitative hydrologic and geothermal data, has been based on the geologic approach, with emphasis on the qualitative effect of local differences in topography, vegetation, climate, geology, and hydrology on the distribution of permafrost. This study shows that the traditional geologic approach, although basic to understanding the distribution, lithology, and structure of rocks and their hydrologic characteristics, does not provide detailed information on the local configuration of permafrost which depends to such a large extent on the thermal regimen. Outlined below are some additional investigations that will increase the amount of basic data and will perhaps increase knowledge of the principles of ground-water occurrence in permafrost regions.

Basic data.-In order to further knowledge of the regional zonation and local configuration of permafrost and occurrence of ground water, an intense effort is required: (1) To collect records of subsurface materials the extent to which they are frozen, and their hydrologic properties, (2) to obtain chemical analyses of ground water, and (3) to measure ground and ground-water temperature and waterlevel fluctuations at significant wells and springs.

Hydrogeologic mapping.-Studies are needed of selected areas in which surface and subsurface geologic mapping, hydrologic methods, and geophysical techniques are combined to describe the lithology, structure, and hydrologic properties of unconsolidated deposits and bedrock, and the configuration of permafrost. The resistivity method may be employed to supplement existing subsurface data, and the seismic-refraction method may be used to determine the configuration of permafrost, particularly beneath bodies of surface water. Results of quantitative aquifer tests should be considered in terms of impermeable boundaries imposed by permafrost as well as those related to lithology and structure of the rocks. Studies should include temperature and chemistry of the water. Special attention should be given to hydrology of springs, icings, and pingos, and to the hydrology of suprapermafrost water and the avenues of recharge and dis- 
charge of subpermafrost water through unfrozen zones that perforate the permafrost. The chemistry of ground ice that cements perennially frozen ground and the study of unfrozen brines within permafrost are important. The effect of permafrost on the base flow of rivers should also be considered in analysis of streamflow records.

Geothermal investigations.-Quantitative aspects of the thermal regimen that influences the configuration of permafrost and basic thermal relations between moving ground water and permafrost can be resolved only by geothermal investigations. The studies already begun in the continuous-permafrost zone of northern Alaska have contributed immeasurably to knowledge of the basic principles of heat flow in the ground and to an understanding of the formation, stability, and degradation of permafrost and its relation to the environment. Geothermal studies need to be expanded into the discontinuouspermafrost zone, preferably in areas where detailed hydrogeologic mapping has been done or is in progress. Quantitative data are needed to calculate the thermal effect of rivers, lakes, glaciers, the ocean, and vegetation on ground-surface temperature. The graphical methods developed by Lachenbruch (1957b) and W. G. Brown (1963) can be extended to studying the thermal effects of surface-water bodies in creating an unfrozen zone above or through the permafrost. Measurements of ground temperature at the surface and to depth and measurements of thermal conductivity of earth materials are needed to determine the history of permafrost and the degree to which its thickness reflects present ground-surface temperature.

\section{REFERENCES}

Annersten, Lennart, 1963, Ground temperature measurements in the Schefferville area, P. Q. (summ.), in Canadian Conference on Permafrost, 1st, Ottawa 1962, Proc.: Natl. Research Council Canada Associate Comm. Soil and Snow Mechanics Tech. Memo. 76, p. 215-217.

Baranov, I. IA., 1958, Map of USSR showing distribution of permafrost thickness and temperature, in TSytovich, N. A., 1958, Osnovaniia i fundamenty na merzlykh gruntakh (Bases and foundations of frozen ground): Moscow, Akad. Nauk SSSR Izdatel'stvo, p. 14, fig. 2.

1959, Geograficheskoe rasprostranenie sezonnopromerzaiushchikh pochv i mnogoletnemerzlykh gornykh porod (Geographical distribution of seasonally frozen ground and permafrost), in Osnovy geokriologii (General geocryology) : Moscow, Akad. Nauk SSSR, pt. I, chap. 7, p. 19.3-219. Translation by A. Nruklik, Natl. Research Council Canada Tech. Translation TT-1121, 85 p.

Barnes, D. F., 1961, Gravity low at Minto Flats, Alaska, in Short papers in the geologic and hydrologic sciences: U.S. Geol. Survey Prof. Paper 424-D, p. D254-D257.
-1965, Geophysical methods for delineating permafrost: Internat. Conf. on Permafrost, Lafayette, Ind., 1963, Proc., p. 349-355.

Barnes, D. F., and MacCarthy, G. R., 1956, Tests of geophysical prospecting techniques in areas of sporadic permafrost in interior Alaska [abs.] in Alaska Sci. Conf., 7th, Juneau, 1956, Proc: Sci. Alaska 1956, p. 41.

1964, Preliminary report on tests of the application of geophysical methods to Arctic ground-water problems: U.S. Geol. Survey open-file report, $37 \mathrm{p}$.

Bateman, A. M., and McLaughlin, D. H., 1920, Geology of the ore deposits of Kennecott, Alaska: Econ. Geology, v. 15, no. 1, p. 1-80.

Benninghoff, W. S., 1965, Relationships between vegetation and frost in soils: Internat. Conf. on Permafrost, Lafayette, Ind., 1963, Proc., p. 9-13.

Black, R. F., 1946, Permafrost investigations at Point Spencer, Alaska: U.S. Geol. Survey Permafrost Program Prog. Rept. 2, 29 p., pub. by Engineer Intelligence Div., Office, Chief of Engineers, U.S. Army.

1950, Permafrost, in Trask, P. D., Applied sedimentation: New York, John Wiley and Sons, chap. 14, p. 247-275.

1951, Eolian deposits of Alaska: Arctic, v. 4, no. 2, p. 89-111.

1954, Permafrost-a review: Geol. Soc. America Bull., v. 65 , p. $839-856$.

1957, Some problems in engineering geology caused by permafrost in the Arctic Coastal Plain, northern Alaska: Arctic, v. 10, no. 4, p. 230-240.

1958, Permafrost, water-supply, and engineering geology of Point Spencer spit, Seward Peninsula, Alaska: Arctic, v. 11, no. 2, p. 102-116.

1964, Gubik Formation of Quaternary age in northern Alaska: U.S. Geol. Survey Prof. Paper 302-C, p. 59-91.

Black, R. F., and Barksdale, W. L., 1948, Terrain and permafrost, Umiat area, Alaska: U.S. Geol. Survey, Permafrost Program Prog. Rept. 5, 23 p., pub. by Eng. Intelligence Div., Office, Chief of Engineers, U.S. Army.

Brandon, L. V., 1965, Evidences of ground-water flow in permafrost regions: Internat. Conf. on Permafrost, Lafayette, Ind., 1963, Proc., p. 176-177.

Bratsev, L. A., 1940, Vechnaia merzlota $\mathrm{v}$ zarubezhnykh stranakh (Permafrost in foreign countries): Akad. Nauk SSSR, Inst. Merzolotovedeniia Trudy, v. 5.

Brewer, M. C., 1958a, Some results of geothermal investigations of permafrost in northern Alaska: Am. Geophys. Union Trans., v. 39, no. 1, p. 19-26.

1958b, The thermal regime of an Arctic lake: Am. Geophys. Union Trans., v. 39, no. 2, p. 278-284.

Broadwell, J. A., 1945, How CAA engineers meet construction problems north of the Arctic Circle: Pacific Builder and Engineer, v. 51, no. 4, p. 55-56.

Brooks, A. H., 1906, The geography and geology of Alaska, a summary of existing knowledge: U.S. Geol. Survey Prof. Paper 45, 327 p.

1907, The Circle precinct, Alaska: U.S. Geol. Survey Bull. 314-K, p. 187-204.

1908, The mining industry in 1907 [Alaska]: U.S. Geol. Survey Bull. 345-A, p. 30-53.

1909 , The mining industry in 1908 [Alaska]: U.S. Geol. Survey Bull. 379-A, p. 21-62. 
1914, The Chisana placer district [Alaska]: U.S. Geol. Survey Bull. 592-I, p. 309-320.

1915, The Alaskan mining industry in 1914: U.S. Geol. Survey Bull. 622-A, p. 15-68.

1922, The Alaskan mining industry in 1920: U.S. Geol. Survey Bull. 722-A, p. 7-74.

Brown, R. J. E., 1960, The distribution of permafrost and its relation to air temperature in Canada and the U.S.S.R.: Arctic, v. 13, no. 3, p. 163-177.

ed., 1963, Canadian Conference on Permafrost, 1st, Ottawa, 1962, Proc.: Natl. Research Council Canada Associate Comm. Soil and Snow Mechanics Tech. Memo. $76,231 \mathrm{p}$.

-1965a, Influence of vegetation on permafrost: Internat. Conf. on Permafrost, Lafayette, Ind., 1963, Proc., p. 20-25.

-1965b, Relation between mean annual air and ground temperatures in the permafrost region of Canada: Internat. Conf. on Permafrost, Lafayette, Ind., 1963, Proc., p. 241-247.

Brown, W. G., 1963, Simple graphical methods for estimating the location of permafrost under shallow lakes and rivers, in Canadian Conference on Permafrost, 1st, Ottawa 1962, Proc.: Natl. Research Council Canada Associate Comm. Soil and Snow Mechanics Tech. Memo. 76, p. 226-231.

Bulmasov, A. P., 1957, Oblast' i usloviia primeneniia geofizicheskikh metodov razvedki $\mathrm{v}$ raionakh mnogoletnei merzloty (The area of applicability and conditions governing the use of geophysical survey methods in permafrost areas), in Materialy po podzemnym vodam Vostochnoi Sibiri: Vostochno-Sibirskii Filial, Akad. Nauk SSSR Irkutsk, p. 157-163.

Capps, S. R., 1911, Mineral resources of the Bonnifield region [Alaska]: U.S. Geol. Survey Bull. 480-H, p. 218-235.

1912, The Bonnifield region, Alaska: U.S. Geol. Survey Bull. 501, 64 p.

1914, Gold lodes and placers of the Willow Creek district [Alaska]: U.S. Geol. Survey Bull. 592-H, p. 245-272.

1919, The Kantishna region, Alaska: U.S. Geol. Survey Bull. 687, 118 p.

1940, Geology of the Alaska Railroad region: U.S. Geol. Survey Bull. 907, 201 p.

Carlson, Harry, 1952, Calculation of depth of thaw in frozen ground, in Frost action in soils, a symposium: Natl. Acad. Sci., Natl. Research Council Pub. 213; Highway Research Board Spec. Rept. 2, p. 192-223.

Cathcart, S. H., 1920, Mining in northwestern Alaska: U.S. Geol. Survey Bull. 712-G, p. 185-198.

Cederstrom, D. J., 1952, Summary of ground-water development in Alaska, 1950: U.S. Geol. Survey Circ. 169, 37 p. 1961a, Origin of a salt-water lens in permafrost at Kotzebue, Alaska: Geol. Soc. America Bull., v. 72, p. 1427-1432.

-1961b, Ground-water hydrology in Alaska, in Geology of the Arctic, v. 2: Toronto, Ontario, Univ. Toronto Press, p. 1014-1019.

1963, Ground-water resources of the Fairbanks area, Alaska: U.S. Geol. Survey Water-Supply Paper 1590, $84 \mathrm{p}$.
Cederstrom, D. J., Johnston, P. M., and Subitzky, Seymour, 1953, Occurrence and development of ground water in permafrost regions: U.S. Geol. Survey Circ. 275, 30 p.

Cederstrom, D. J., and Péwé, T. L., 1961, Ground-water data, Fairbanks area, Alaska: Alaska Dept. Health and Welfare Hydrol. Data Rept. 9, 28 p.

Cederstrom, D. J., and Tibbitts, G. C., Jr., 1961, Jet drilling in the Fairbanks area, Alaska: U.S. Geol. Survey Water-Supply Paper 1539-B, p. B1-B28.

Cederstrom, D. J., Wahrhaftig, Clyde, and Barnes, F. F., 1950, Ground water in the vicinities of Healy and Homer, Alaska: U.S. Geol. Survey open-file report, 4 p.

Chadwick, R. H. W., 1960, Copper deposits of the Ruby Creek area, Ambler River quadrangle, Alaska: Alaska Section, Am. Inst. Min. Engineers, 5th, College, April 1960.

Chapman, R. M., and Sable, E. G., 1960, Geology of the Utukok-Corwin region, northwestern Alaska: U.S. Geol. Survey Prof. Paper 303-C, p. 47-167.

Chekotillo, A. M., 1940, Naledi i bor'ba s nimi (Icings and countermeasures): Gushosdor NKVD, Moscow, M. I. Sumgin (ed.), Instituta Merzlotovedeniia im. V. A. Obrucheva, 136 p., Translation, in St. Anthony Falls Hydraulic Lab., Minnesota Univ., Investigation of airfield drainage, Arctic and Subarctic regions: U.S. Army, Corps of Engineers, St. Paul district, pt. 2, 1949, p. 99-148.

Collins, F. R., 1958a, Test wells, Umiat area, Alaska, with Micropaleontological study of the Umiat field, northern Alaska, by $\mathrm{H}$. R. Bergquist, and sections on Temperature measurement studies by $\mathrm{M}$. C. Brewer, and Core analyses, Umiat test well 9, by G. L. Gates: U.S. Geol. Survey Prof. Paper 305-B, p. 71-206.

1958b, Test wells, Topagoruk area, Alaska, with micropaleonotological study of the Topagoruk test wells, northern Alaska, by H. R. Bergquist: U.S. Geol. Survey Prof. Paper 305-D, p. 265-316.

-1958c, Test wells, Meade and Kaolak areas, Alaska, with Micropaleontology of Meade test well 1 and Kaolak test well 1, northern Alaska, by H. R. Bergquist: U.S. Geol. Survey Prof. Paper 305-F, p. 341-376.

-1959, Test wells, Square Lake and Wolf Creek areas, Alaska, with Micropaleontology of Square Lake test well 1 and Wolf Creek test wells, northern Alaska, by H. R. Bergquist: U.S. Geol. Survey Prof. Paper 305-H, p. 423-484.

-1961 , Core tests and test wells, Barrow area, Alaska, with a section on Temperature measurement studies, by M. C. Brewer: U.S. Geol. Survey Prof. Paper 305-K, p. 569-644.

Coulter, H. W., Hussey, K. M., and O'Sullivan, J. B., 1960, Radiocarbon dates relating to the Gubik formation northern Alaska, in Short papers in the geological sciences: U.S. Geol. Survey Prof. Paper 400-B, p. B350-B351.

Coulter, H. W., and others, 1965, Map showing extent of glaciations in Alaska: U.S. Geol. Survey Misc. Geol. Inv. Map I-415.

Crowley, F. A., and Hanson, R. E., 1956, Seismic measurements in permafrost areas of interior Alaska [abs.], in 
Alaskan Sci. Conf., 7th, Juneau 1956, Proc: Sci. Alaska 1956, p. 54.

Dall, W. H., 1870, Alaska and its resources: Boston, Lee, and Shepard, $627 \mathrm{p}$.

Eakin, H. M., 1912, The Rampart and Hot Springs regions [Alaska]: U.S. Geol. Survey Bull. 520-I, p. 271-286.

-1913a, Gold placers of the Ruby district [Alaska]: U.S. Geol. Survey Bull. 542-G, p. 279-292.

$1913 \mathrm{~b}$, Gold placers of the Innoko-Iditarod region [Alaska]: U.S. Geol. Survey Bull. 542-G, p. 293-303.

1913c, A geologic reconnaissance of a part of the Rampart quadrangle, Alaska: U.S. Geol. Survey Bull. $535,38 \mathrm{p}$.

1914a, The Iditarod-Ruby region, Alaska: U.S. Geol. Survey Bull. 578, 45 p.

1914b, Placer mining in the Ruby district [Alaska]: U.S. Geol. Survey Bull. 592-J, p. 363-369.

1915a, Mining in the Fairbanks district [Alaska]:

U.S. Geol. Survey Bull. 622-G, p. 229-238.

1915b, Mining in the Hot Springs district [Alaska]: U.S. Geol. Survey Bull. 622-G, p. 239-245.

Ellsworth, C. E., 1910, Placer mining in the Yukon-Tanana region [Alaska]: U.S. Geol. Survey Bull. 442-F, p. 230-245.

Ellsworth, C. E., and Davenport, R. W., 1913, Placer mining in the Yukon-Tanana region [Alaska]: U.S. Geol. Survey Bull. 542-F, p. 203-222.

Ellsworth, C. E. and Parker, G. L., 1911, Placer mining in the Yukon-Tanana region [Alaska]: U.S. Geol. Survey Bull. 480-G, p. 153-172.

Engineering and Mining Journal, 1915, Koyukuk placer mining district [Alaska]: Eng. Mining Jour., v. 99, p. 1021-1023.

Fernald, A. T., 1959, Geomorphology of the Upper Kuskokwim region, Alaska: U.S. Geol. Survey Bull. 1071-G, p. 191-279.

Ferrians, O. J., Jr., 1963, Glaciolacustrine diamicton deposits in the Copper River Basin, Alaska, in Short papers in geology and hydrology: U.S. Geol. Survey Prof. Paper 475-C, p. C120-C125.

-1965, Permafrost map of Alaska: U.S. Geol. Survey Misc. Geol. Inv. Map I-445.

Ferrians, O. J., Jr., Nichols, D. R., and Schmoll, H. R., 1958, Pleistocene volcanic mudflow in the Copper River Basin, Alaska [abs.]: Geol. Soc. America Bull., v. 69, no. 12, p. 1563.

Ferrians, O. J., Jr., and Schmoll, H. R., 1957, Extensive proglacial lake of Wisconsin age in the Copper River Basin, Alaska [abs.]: Geol. Soc. America Bull., v. 68, no. 12 , p. 1726 .

Feulner, A. J., 1960, Data on Wells at Ladd Air Force Base, Alaska: Alaska Dept. Health and Welfare Hydrol. Data Rept. 13, $16 \mathrm{p}$.

Feulner, A. J., and Schupp, R. G., 1963, Seasonal changes in western Alaska, in Short papers in geology and hydrology: U.S. Geol. Survey Prof. Paper 475-B, p. B189B191.

1964, Temperature and chemical quality of water from a well drilled through permafrost near Bethel, Alaska, Geological Survey research 1964: U.S. Geol. Survey Prof. Paper 501-D, p. D144-D148.
Feulner, A. J., and Williams, J. R., 1967, Development of a ground-water supply at Cape Lisburne, Alaska, by modification of the thermal regime of permafrost in Geological Survey research 1967: U.S. Geol. Survey Prof. Paper 575-B, p. B199-B202.

Fisher, J. E., 1953, the cold ice tunnel on the Silbesattel, Monte Rosa: Preliminary report: Jour. Glaciology, v. 2, no. 13 , p. 195-196.

Frost, R. E., McLerran, J. H., and Leightly, R. D., 1965, Photointerpretation in the Arctic and Sub-Arctic: Internat. Conf. on Permafrost, Lafayette, Ind., 1963, Proc. p. 343-348.

Gibson, Arthur, 1914, Thawing frozen ground for placer mining: Mining and Sci. Press, v. 108, p. 143-145.

Grantz, Arthur, White, D. E., Whitehead, H. C., and Tagg A. R., 1962, Saline springs, Copper River Lowland, Alaska: Am. Assoc. Petroleum Geologists Bull., v. 46, no. 11, p. 1990-2002.

Harrington, G. L., 1921, Mineral resources of the Goodnews Bay region [Alaska]: U.S. Geol. Survey Bull. 714-E, p. 207-228.

Hennion, Frank, 1955, Frost and permafrost definitions: Natl. Research Council, Highway Research Board Bull. 11, p. 107-110.

Hershey, O. H., 1909, The ancient Kobuk glacier of Alaska: Jour. Geology, v. 17, p. 83-91.

Hess, F. L., 1906, The York tin region [Alaska]: U.S. Geol. Survey Bull. 284, p. 145-157.

Holmes, G. W., Hopkins, D. M., and Foster, H. L. 1965 Distribution and age of pingos of interior Alaska: Internat. Conf. on Permafrost, Lafayette, Ind., 1963, Proc., p. 88-93.

Hopkins, D. M., 1949, Thaw lakes and thaw sinks in the Imuruk Lake area, Seward Peninsula, Alaska: Jour. Geology, v. 57, no. 2, p. 119-131.

1963 , Geology of the Imuruk Lake area, Seward Peninsula, Alaska: U.S. Geol. Survey Bull. 1141-C, p. C1-C101.

Hopkins, D. M., Karlstrom, T. N. V., and others, 1955, Permafrost and ground water in Alaska: U.S. Geol. Survey Prof. Paper 264-F, p. 113-146.

Hopkins, D. M., MacNeil, F. S., and Leopold, E. B., 1960, The coastal plain at Nome, Alaska-A late Cenozoic type section for the Bering Strait region: Internat. Geol. Cong., 21st, Copenhagen, 1960, Rept., pt. 4, p. $46-57$.

Hopkins, D. M., McCulloch, D. S., and Janda R. J. 1962, Pleistocene stratigraphy and structure of Baldwin Peninsula, Kotzebue Sound, Alaska [abs.] in Alaskan Sci. Conf., 12th, College 1961, Proc.: Sci. Alaska 1961, p. 150-151.

Ives, P. C., Levin, Betsy, Robinson R. D., and Rubin, Meyer, Jour. Glaciology, v. 3, no. 28, p. 789-790.

Ives, P. C., Levin, Betsy, Robinson R. D. and Rubin Meyer 1964, U.S. Geological Survey radiocarbon dates VII: Radiocarbon, v. 6, p. 37-76.

Jaillite, W. M., 1947, Permafrost research area: Mil. Engineer, v. 39, p. 375-379.

Jenness, J. L., 1949, Permafrost in Canada: Arctic, v. 2, p. 13-27.

Joesting, H. R., 1941, Magnetometer and direct-current resistivity studies in Alaska: Am. Inst. Mining Metall. Engineers Trans., v. 164, p. 66-87. 
1954, Geophysical exploration in Alaska: Arctic, v. 7, p. $165-175$.

Johnston, G. H., and Brown, R. J. E., 1961, Effect of a lake on distribution of permafrost in the Mackenzie River Delta: Nature, v. 192 , no. 4799 , p. 251-252.

1963, Effect of a lake on distribution of permafrost in the Mackenzie River Delta (summ.) in Canadian Conference on Permafrost, 1st, Ottawa 1962, Proc.: Natl. Research Council Canada Associate Comm. Soil and Snow Mechanics Tech. Memo. 76, p. 218-225, repr. in Arctic, v. 17, no. 3, p. 162-175, [1964].

Kachadoorian, Reuben, 1960, Engineering and surficial geology of the Nenana-Rex area, Alaska: U.S. Geol. Survey Misc. Geol. Inv. Map I-307.

Karlstrom, T. N. V., 1964, Quaternary geology of the Kenai Lowland and glacial history of the Cook Inlet region, Alaska: U.S. Geol. Survey Prof. Paper 443, 69 p.

Karlstrom, T. N. V., and others, 1964, Surficial geology of Alaska: U.S. Geol. Survey Misc. Geol. Inv. Map I-357.

Kellogg, C. E., and Nygard, I. J., 1951, Exploratory study of the principal soil groups of Alaska: U.S. Dept. Agriculture, Agr. Mon. 7, $138 \mathrm{p}$.

Kotzebue, Otto von, 1821 , A voyage of discovery into the South Sea and Bering's Straits in the years 1815-18, v. 1; translated from the German by H. E. Lloyd: London, Longman, Hurst, Rees, Orme and Brown, 3 v.

Lachenbruch, A. H., 1957a, Thermal effects of the ocean on permafrost: Geol. Soc. America Bull., v. 68, p. 1515-1530.

1957b, Three-dimensional heat conduction in permafrost beneath heated buildings: U.S. Geol. Survey Bull. 1052-B, p. 51-69.

1959, Periodic heat flow in a stratified medium with application to permafrost problems: U.S. Geol. Survey Bull. 1083-A, p. 1-36.

1960, Preliminary interpretation of geothermal data from Ogotoruk Creek, Alaska, in Kachadoorian, Reuben, and others, 1960 Supplementary report on geologic investigations in support of Phase II, Project Chariot in the vicinity of Cape Thompson, northwestern Alaska, p. 7-23: U.S. Geol. Survey open-file report (TEI-764), $30 \mathrm{p}$.

Lachenbruch, A. H., and Brewer, M. C., 1959, Dissipation of the temperature effect of drilling a well in Arctic Alaska: U.S. Geol. Survey Bull. 1083-C, p. 73-109.

1962, Geothermal evidence for recent climatic change near Barrow, Alaska [abs.] in Alaskan Sci. Conf., 12th, College 1961, Proc.: Sci. Alaska 1961, p. 127.

Lachenbruch, A. H., Brewer, M. C., Greene, G. W., and Marshall B. V. 1962, Temperatures in permafrost in Temperature-itsmeasurement and control in science and industry: New York, Reinhold Pub. Corp., v. 3, pt. 1, p. 791-803.

Lachenbruch, A. H., Greene, G. W., and Marshall, B. V., 1960, Preliminary results of geothermal studies at Ogotoruk Creek, AEC Project Chariot Test Site, northwestern Alaska [abs.], in Alaskan Sci. Conf., 11th, Anchorage 1960, Proc.: Sci. Alaska 1960, p. 167.

1961, Interim report on geothermal studies, Ogotoruk Valley, northerwest Alaska, in Kachadoorian, Reuben, and others, 1961, Geologic investigations in support of Project Chariot, Phase III, in the vicinity of Cape
Thompson, northwestern Alaska-Preliminary report, p. 66-79: U.S. Geol. Survey open-file report (TEI-779), $104 \mathrm{p}$.

Lamphere, E. M., and Page, W. B., 1956, Final report on water supply for proposed ANHS hospital at Kotzebue, Alaska: Arctic Health Research Center, Anchorage, unpub. rept., $48 \mathrm{p}$.

Leffingwell, E. deK., 1919, The Canning River region, northern Alaska: U.S. Geol. Survey Prof. Paper 109, 251 p.

Lewis, C. R., 1962, Icing mound on Sadlerochit River, Alaska: Arctic, v. 15, no. 2, p. 145-150.

Lliboutry, Louis, 1957, Studia kropedologiczne w Andach srodkowe-chilijskich (Cryopedological studies in the Andes of central Chile): Biuletyn Periglacjalny, no. 5, p. 5-10.

Lohr, E. W., 1957, Chemical character of public water supplies of the larger cities in Alaska, Hawaii, and Puerto Rico 1954: U.S. Geol. Survey Water-Supply Paper 1460-A; p. 1-39.

MacCarthy, G. R., 1952, Geothermal investigations on the Arctic slope of Alaska: Am. Geophys. Union Trans., v. 33 , no. 4 , p. 589-593.

Mackay, J. R., 1965, Pingos in Canada: Internat. Conf. on Permafrost, Lafayette, Ind., 1963, Proc., p. 71-76.

Maddren, A. G., 1909, Gold placers of the Innoko district [Alaska]: U.S. Geol. Survey Bull. 379-E, p. 238-266. 1910a, The Innoko gold-placer district [Alaska]: U.S. Geol. Survey Bull. 410, 87 p.

1910b, The Koyukuk-Chandalar gold region [Alaska]: U.S. Geol. Survey Bull. 442-G, p. 284-315.

1911, Gold-placer mining developments in the InnokoIditarod region [Alaska]: U.S. Geol. Survey Bull. 480-I, p. 236-270.

1913, The Koyukuk-Chandalar region, Alaska: U.S. Geol. Survey Bull. 532, 119 p.

-1915, Gold placers of the Lower Kuskokwim, with a note on copper in the Russian Mountains [Alaska]: U.S. Geol. Survey Bull. 622-H, p. 292-360.

Maksimov, V. M., and Tolstikhin, N. I., 1940, On hydrogeological conditions in the vicinity of the town of Yakutsk: Acad. sci. URSS Comptes rendus (Doklady), v. 28, no. 1, p. 93-96, [English].

Martin, G. C., 1919, The Alaskan mining industry in 1917: U.S. Geol. Survey Bull. 692-A, p. 11-42.

Mathews, W. H., 1955, Permafrost and its occurrence in the southern Coast Mountains of British Columbia: Canadian Alpine Jour., v. 38, p. 94-98.

Meinzer, O. E., 1923, Outline of ground-water hydrology, with definitions: U.S. Geol. Survey Water-Supply Paper 494, $71 \mathrm{p}$.

Meister, L. A., 1955, O nedostatkakh klassifikatsii podzemnykh mnogoletnemerzlykh gornykh porod (Shortcomings in the classification of ground water in permafrost) : Akad. Nauk SSSR, Inst. Merzlotovedeniia, Materialy $\mathbf{k}$ osnovam ucheniia o merzlykh zonakh zemnoi kory, no. 2 , p. 59-64.

Mertie, J. B., Jr., 1930, Mining in the Fortymile district [Alaska]: U.S. Geol. Survey Bull. 813-C, p. 125-142.

1934, Mineral deposits of the Rampart and Hot Springs districts [Alaska]: U.S. Geol. Survey Bull. 844-D, p. 163-226.

1936, Mineral deposits of the Ruby-Kuskokwim region, 
Alaska: U.S. Geol. Survey Bull. 864-C, p. 115-245. 1937, The Yukon-Tanana region, Alaska: U.S. Geol. Survey Bull. 872, 276 p.

Mertie, J. B., Jr., and Harrington, G. L., 1916, Mineral resources of the Ruby-Kuskokwim region [Alaska]: U.S. Geol. Survey Bull. 642-H, p. 223-266.

-1924, The Ruby-Kuskokwim region, Alaska: U.S. Geol. Survey Bull. 754, 129 p.

Middendorf, A. Th. von, 1848, Geotermische Beobachtungen (Geothermal observations), in Reise in den äussersten Norden und Osten Sibiriens: Kaiserl. Akad, der Wissensch., St. Petersburg, v. 1, pt. 1, p. 83-184.

-1867, Übersicht der Natur Nord- und Ost-Sibiriens (Natural history of northern and eastern Siberia), in Reise in den äussersten Norden und Osten Sibiriens, v. 4, pt. 1, $783 \mathrm{p}$.

Miller, R. D., and Dobrovolny, Ernest, 1959, Surficial geology of Anchorage and vicinity, Alaska: U.S. Geol. Survey Bull. 1093, 127 p.

Mining and Scientific Press, 1909, Nome, Alaska-Artificial freezing of flooded mines, etc.: Mining and Sci. Press, v. 99, p. 315.

Mining Engineering, 1961, Alaska regional report: Mining Eng., v. 13, no. 12, p. 1315-1356.

Misener, A. D., 1955, Heat flow and depth of permafrost at Resolute Bay, Cornwallis Island, N. W. T., Canada: Am. Geophys. Union Trans., v. 36, no. 6, p. 1055-1060.

Moffit, F. H., 1905, The Fairhaven gold placers, Seward Peninsula, Alaska: U.S. Geol. Survey Bull. 247, 83 p.

-1907 , The Nome region, Alaska: U.S. Geol. Survey Bull. 314-G, p. 126-145.

1912, The Chitina copper district [Alaska]: U.S. Geol. Survey Bull. 520-C, p. 105-107.

1927, Mineral industry of Alaska in 1925: U.S. Geol. Survey Bull. 792-A, p. 1-39.

1941, Geology of the upper Tetling River district, Alaska: U.S. Geol. Survey Bull. 917-B, p. 115-157.

1954, Geology of the eastern part of the Alaska Range and adjacent area: U.S. Geol. Survey Bull. 989-D, p. 68-218.

Moffit, F. H., and Capps, S. R., 1911, Geology and mineral resources of the Nizina District, Alaska: U.S. Geol. Survey Bull. 448, 108 p.

Moffit, F. H., and Maddren, A. G., 1908, The mineral resources of the Kotsina and Chitina Valleys, Copper River region [Alaska]: U.S. Geol. Survey Bull. 345-C, p. $127-175$.

Mohr, J. L., and others, 1961, The marine nature of Nuwuk Lake and small ponds of the peninsula of Point Barrow, Alaska: Arctic, v. 14, no. 4, p. 211-223.

Moore, E. W., 1949, A summary of available data on quality of Arctic waters: Natl. Research Council, Div. Med. Sci., Rept. to Subcomm. on Water Supply of Comm. on Sanitary Eng. and Environment, $14 \mathrm{p}$.

1950, Summary of additional data on Alaskan waters: Natl. Research Council, Div. Med. Sci., Rept. to Subcomm. on Water Supply of Comm. on Sanitary Eng. and Environment, 25 p.

Mordvinov, A. I., 1940, Rel'ef i vechnaia merzlota levobereg'ia srednego techeniia $r$. Byssy i prilegaiushchikh predgorii zapadnogo sklona Turanskogo Khrebta (Relief and permafrost of the left bank of the Byssa River and of the adjacent foothill zone of the western slope of the Turan Range): Akad. Nauk SSSR, Kom. vechnoi merzlota, Trudy, v. 9, p. 50-134.

Müller, Fritz, 1959, Beobachtungen über pingos: Medd. om Grønland, v. 153, no. 3, 127 p. (Observations on pingos: translated, 1963, by D. A. Sinclair, Natl. Research Council of Canada, Tech. Translation TT-1073, 117 p.)

Muller, S. W., 1947, Permafrost or perennially frozen ground and related engineering problems: Ann Arbor, Mich., Edwards Brothers, 231 p.

Nichols, D. R., 1956, Permafrost and ground-water conditions in the Glennallen area, Alaska: U.S. Geol. Survey open-file report, $14 \mathrm{p}$.

-1965, Permafrost in the Holocene Epoch: Internat. Conf. on Permafrost, Lafayette, Ind., 1963, Proc., p. 172-175.

Nichols, D. R., and Yehle, L. A., 1961a, Mud volcanoes in the Copper River Basin Alaska, in Geology of the Arctic, v. 2: Toronto, Ontario. Toronto Univ. Press, p. 1063-1087.

$-1961 b$, Analyses of gas and water from two mineral springs in the Copper River Basin, Alaska, in Short papers in the geologic and hydrologic sciences: U.S. Geol. Survey Prof. Paper 424-D, p. D191-D194.

Nikiforoff, C. C., 1928, The perpetually frozen subsoil of Siberia: Soil Sci., v. 26, p. 61-77.

Payne, T. G., and others, 1952, Geology of the Arctic slope of Alaska: U.S. Geol. Survey Oil and Gas Inv. Map OM-126.

Petrov, V. G., 1930, Naledi na Amurskogo-IAkutskoi magristrali (Icings on the Amur-Yakutsk highway): Leningrad, Akad. Nauk SSSR i Nauchn.-issled avtomobil'nodorozhnogo Inst., $177 \mathrm{p}$.

-1934, Opyt opredeleniia sily davleniia gruntovykh vod $\mathrm{v}$ nalediahk (An attempt at determining the pressure of ground water in icing mounds): Akad. Nauk SSSR, Kom. izuch. vechnoi merzloty, Trudy, v. 3, p. 59-72.

Petrovskii, A. A., and Dostovalov, B. M., 1947, Volnomernyi metod $\mathrm{v}$ primenenii $\mathrm{k}$ izucheniiu verkhniago sloia pochvy (Application of the wave-length method to the study of the upper layers of the ground): Akad. Nauk SSSR, Institut Merzlotovedeniia, Trudy, v. 5, p. 161-174.

Péwé, T. L., 1947, Permafrost and geomorphology in the lower Yukon Valley, Alaska [abs.]: Geol. Soc. America Bull., v. 58, p. 1257.

1948a, Terrain and permafrost, Galena area [Alaska]: U.S. Geol. Survey, Permafrost Program Prog. Rept. 7, 52 p., pub. by Engineer Intelligence Div., Office, Chief of Engineers, U.S. Army.

1948b, Permafrost investigations, Fairbanks area, Alaska: U.S. Geol. Survey, Permafrost Program Prelim, Rept., 16 p., pub. by Engineer Intelligence Div., Office, Chief of Engineers, U.S. Army, Sept.

1952, Permafrost investigations in the Fairbanks area, Alaska [abs.] in Alaskan Sci. Conf., 3d, Mount McKinley Natl. Park 1952, Proc.: Sci. Alaska 1952, p. 169.

1953, Brief review of Pleistocene events and climatic changes in Alaska: U.S. Geol. Survey open-file report, $14 \mathrm{p}$.

1958a, Geology of the Fairbanks (D-2) quadrangle, Alaska: U.S. Geol. Survey Geol. Quad. Map GQ-110. 
-1958b, Permafrost and its effect on life in the north: Oregon State Coll. Biol. Colloquium, 18th, Corvallis, Proc., p. 12-15.

1965, Ice wedges in Alaska-Classification, distribution, and climatic significance: Internat. Conf. on Permafrost, Lafayette, Ind., 1963, Proc., p. 76-81.

Péwé, T. L., and Holmes, G. W., 1964, Geology of the Mount Hayes D-4 quadrangle, Alaska: U.S. Geol. Survey Misc. Geol. Inv. Map I-394.

Péwé, T. L., and Rivard, N. R., 1961, Geologic map and section of the Fairbanks D-3 quadrangle, Alaska: U.S. Geol. Survey Misc. Geol. Inv. Map I-340.

Pinkow, Hans-Heinz, 1943, Erdolvorkommen in den arktischen Regionen der Sowjet Union (Occurrence of oil in the Arctic regions of the Soviet Union) : Zeitschr. prakt. Geologie, v. 51, no. 12, p. 132-136.

Piper, A. M., 1961, Potential effects of Project Chariot on local water supplies: U.S. Geol. Survey open-file report (TEI-810), $76 \mathrm{p}$.

Porsild, A. E., 1938, Earth mounds in unglaciated arctic northwestern America: Geog. Rev., v. 28, p. 46-58.

Prindle, L. M., 1905, The gold placers of the Fortymile, Birch Creek, and Fairbanks regions, Alaska: U.S. Geol. Survey Bull. 251, 39 p.

1908a, The Fortymile gold placer district [Alaska]: U.S. Geol. Survey Bull. 345-D, p. 187-197.

1908b, The Fairbanks and Rampart quadrangles, Yukon-Tanana region, Alaska, with a section on the Rampart placers by F. L. Hess, and a paper on the water supply of the Fairbanks region by C. C. Covert: U.S. Geol. Survey Bull. 337, 102 p.

1913a, A geologic reconnaissance of the Circle quadrangle, Alaska: U.S. Geol. Survey Bull. 538, 82 p.

-1913b, A geologic reconnaissance of the Fairbanks quadrangle, Alaska, with a detailed description of the Fairbanks district, by L. M. Prindle and F. J. Katz, and an account of lode mining near Fairbanks, by $P$. $S$. Smith: U.S. Geol. Survey Bull. 525, 220 p.

Prindle, L. M., and Hess, F. L., 1906, The Rampart gold placer region, Alaska: U.S. Geol. Survey Bull. 280, 54 p.

Prindle, L. M., and Katz, F. J., 1909, The Fairbanks goldplacer region [Alaska]: U.S. Geol. Survey Bull. 379-E, p. 181-200.

Purington, C. W., 1905, Methods and costs of gravel and placer mining in Alaska: U.S. Geol. Survey Bull. 263, $273 \mathrm{p}$.

Ray, L. L., 1952, Perennially frozen ground, an environmental factor in Alaska: Internat. Geog. Cong., 17th, and 8th Gen. Assembly, Washington, D. C., 1952, Proc., p. 260-264.

Ray, P. H., 1885, Report of the International Polar Expedition to Point Barrow, Alaska: Washington, U.S. Govt. Printing Office, $695 \mathrm{p}$.

Ray, R. G., 1954, Geology and ore deposits of the Willow Creek mining district, Alaska: U.S. Geol. Survey Bull. 1004, 86 p.

Reed, J. C., 1958, Exploration of Naval Petroleum Reserve No. 4 and adjacent areas, northern Alaska, 1944-53; part 1, History of the exploration: U.S. Geol. Survey Prof. Paper 301, 192 p.

Richardson, John, 1841, On the frozen soil of North America: Edinburgh New Philos. Jour., v. 30, p. 110-123.
1854, The zoology of the voyage of the HMS Herald under Captain Henry Kellett, during the years of 1845-51: London.

Rickard, T. A., 1909, Drilling in alluvial ground in Alaska: Mining and Sci. Press, v. 99, p. 558-559.

Robinson, F. M., 1956, Core tests and test wells, Oumalik area, Alaska, with Paleontology of test wells and core tests in the Oumalik area, Alaska, by H. R. Bergquist: U.S. Geol. Survey Prof. Paper 305-A, p. 1-70.

1958a, Test well, Grandstand area, Alaska, with Micropaleontologic study of Grandstand test well 1, northern Alaska, by H. R. Bergquist: U.S. Geol. Survey Prof. Paper 305-E, p. 317-339.

1958b, Test wells Gubik area, Alaska, with Micropaleontologic study of the Gubik test wells, northern Alaska, by H. R. Bergquist: U.S. Geol. Survey Prof. Paper 305-C, p. 207-264.

1959a, Test wells, Titaluk and Knifeblade areas, Alaska, with Micropaleontologic study of test wells in the Titaluk and Knifeblade areas, northern Alaska, by H. R. Bergquist: U.S. Geol. Survey Prof. Paper 305-G, p. $377-422$.

-1959b, Test wells, Simpson area, Alaska, with a section on Core analyses, by S. T. Yuster: U.S. Geol. Survey Prof. Paper 305-J, p. 523-568.

1964, Core tests, Simpson area, Alaska, with a section on Temperature measurement studies, by M. C. Brewer : U.S. Geol. Survey Prof. Paper 305-L, p. 645-730.

Robinson, F. M., and Collins, F. R., 1959, Core test, Sentinel Hill area and test well Fish Creek area, Alaska: U.S. Geol. Survey Prof. Paper 305-I, p. 485-521.

Roethlisberger, Hans, 1961, Seismic refraction soundings in permafrost near Thule, Greenland, in Geology of the Arctic, v. 2: Toronto, Ontario, Univ. Toronto Press. p. 970-980.

Rutledge, F. A., Thorne, R. L., Kerns, W. H., and Mulligan, J. J. 1953, Preliminary report: Nonmetallic deposits accessible to the Alaska Railroad as possible sources of raw material for the construction industry: U.S. Bur. Mines Rept. Inv. 4932, $129 \mathrm{p}$.

Shumskii, P. A., 1959, Sovetskie gliatsiologicheskie issledovaniia $\mathrm{v}$ Antarktide (Soviet glaciological investigations in Antarctica) : Seism. i gliatsiol. issled. v. Period MGG, Sbornik Statei, no. 2, p. 77-83.

Shvetsov, P. F., 1951, $\mathrm{K}$ opredeleniiu nekotorykh poniatti $\mathrm{v}$ merzlotovedenii (Definitions of some terms in permafrostology) : Akad. Nauk SSSR, Izv. Ser. geog., no. 5, p. 83-87.

Sigafoos, R. S., 1951, Soil instability in tundra vegetation: Ohio Jour. Sci., v. 51, no. 6, p. 281-298.

Slaughter, M. J., 1961, Surface-water discharge of Ogotoruk Creek near Cape Thompson, Alaska, in Kachadoorian, Reuben, and others, 1961, Geologic investigations in support of Project Chariot, Phase III, in the vicinity of Cape Thompson, northwestern Alaska-preliminary report, p. 102-104: U.S. Geol. Survey open-file report (TEI-779), $104 \mathrm{p}$.

Smith, P. S., 1909, Recent developments in southern Seward Peninsula [Alaska]: U.S. Geol. Survey Bull. 379-F, p. 267-301.

1913, The Noatak-Kobuk region, Alaska: U.S. Geol. Survey Bull. 536, 160 p. 
1934, Mineral industry of Alaska in 1931: U.S. Geol. Survey Bull. 844-A, p. 1-82.

1939, Areal geology of Alaska: U.S. Geol. Survey Prof. Paper 192, 100 p.

1942, Mineral industry of Alaska in 1940: U.S. Geol. Survey Bull. 933-A, p. 1-102.

Smith, P. S., and Eakin, H. M., 1911, The Shungnak region, Kobuk Valley [Alaska]: U.S. Geol. Survey Bull. 480-J, p. 271-305.

Spetzman, L. A., 1959, Vegetation of the Arctic Slope of Alaska: U.S. Geol. Survey Prof. Paper 302-B, p. 19-58.

Stefansson, Vilhjalmur, 1910, Underground ice in northern Alaska: Am. Geog. Soc. Bull., v. 42, p. 337-345.

Streiff-Becker, R., 1953, Extrusion flow in glaciers: Jour. Glaciology, v. 2, no. 13, p. 181-182.

Sturgis, S. D., Jr., 1953, Arctic engineering know-how gets acid test at Thule: Civil Eng. v. 23, no. 9, p. 585-589.

Sumgin, M. I., and others, 1940, Obshchee merzlotovedenie (General permafrostology): Moscow-Leningrad, Akad. Nauk SSSR, 340 p.

Taber, Stephen, 1943, Perennially frozen ground in Alaska: its origin and history: Geol. Soc. America Bull., v. 54, p. 1433-1548.

Terzaghi, Karl, 1952, Permafrost: Boston Soc. Civil Engineers Jour., v. 39, no. 1, p. 1-50.

Theis, C. V., 1944, Thermal processes related to the formation of permafrost: U.S. Geol. Survey open-file report, $36 \mathrm{p}$.

Thomas, B. I., 1957, Tin-bearing placer deposits near Tofty, Hot Springs district, central Alaska: U.S. Bur. Mines Rept. Inv. 5373, 56 p.

Tien, Chi, 1960, Temperature distribution of an idealized ice cap: U.S. Army Corps of Engineers, Snow Ice and Permafrost Research Establishment, Research Rept. 64, 8 p.

Tolstikhin, N. I., 1941, Podzemnye vody merzloi zony litosfery (Ground water of the frozen zone of the lithosphere) : Moscow-Leningrad, Gosgeolizdat, 201 p.

Tolstikhin, N. I., Vel'mina, N. A., and Efimov, A. I., 1963, Gidrogeologiia oblasti mnogoletnemerzlykh porod Sovetskogo soiuza (The hydrogeology in the permafrost zones of the U.S.S.R.), in TSytovich, N. A. (ed.), Doklady na mezhdunarodnoi konferentsii po merzlotovedeniiu (Reports in the International Conference on Permafrost): Moscow, Acad. Nauk SSSR, Instl. Merzlotovedeniia im. V. A. Obrucheva, p. 158-166.

Tuck, Ralph, 1940, Origin of the muck-silt deposits at Fairbanks, Alaska: Geol. Soc. America Bull., v. 51, p. 1295-1310.

Tulina, L. N., 1936, O lesnoi rastitel'nosti Anadyrskogo Kraia i yeye vzaimootnoshenii s tundroi (Forest vegetation of the Anadyr region and its correlation with the tundra): Leningrad, Arctic Inst. Trans., v. 40, p. 1-212 (partial translation by Marcella Woerheide, U.S. Geol. Survey).

U.S. Geological Survey, 1958, Quantity and quality of surface waters of Alaska, October 1950 to September 1953: U.S. Geol. Survey Water-Supply Paper 1466, 243 p.

1963a, Surface water records of Alaska, 1961: U.S. Geol. Survey, Water Resources Div., 131 p.

1963b, Surface water records of Alaska, 1962: U.S. Geol. Survey, Water Resources Div., 138 p. 1963c, Permafrost, in Summary of investigations: U.S. Geol. Survey Prof. Paper 475-A, p. A173-A174.

Wahrhaftig, Clyde, 1958, Quaternary geology of the Nenana River valley and adjacent parts of the Alaska Range: U.S. Geol. Survey Prof. Paper 293-A, p. 1-68.

Wallace, R. E., 1946, Terrain analysis in the vicinity of Northway, Alaska with special reference to permafrost: U.S. Geol. Survey Permafrost Program, Prog. Rept. 3, 34 p., pub. by Engineer Intelligence Div., Office, Chief of Engineers, U.S. Army.

1948, Cave-in lakes in the Nebesna, Chisana, and Tanana River valleys, eastern Alaska: Jour. Geology, v. 56, p. 171-181.

Waller, R. M., 1957a, Ground water and permafrost at Bethel, Alaska: Alaska Dept. Health and Welfare Hydrol. Data Rept. 2, 11 p.

1957b, Ground-water reconnaissance of six Eskimo villages in the Kobuk-Noatak area, Alaska: Alaska Dept. Health and Welfare Hydrol. Data Rept. 4, 8 p.

1957c, Riverbank erosion and ground-water conditions at Beaver, Alaska: U.S. Geol. Survey open-file report, 6 p.

1958, Ground-water reconnaissance in five Eskimo villages in the lower Kuskokwim-Yukon River area, Alaska: Alaska Dept. Health and Welfare Hydrol. Data Rept. 5, 11 p.

1959a, Water-resources reconnaissance of Gambell and Savoonga villages, St. Lawrence Island, Alaska: Alaska Dept. Health and Welfare Hydrol. Data Rept. 6, 14 p.

$-1959 \mathrm{~b}$, Ground-water reconnaissance of Koyuk and Shaktolik villages, Alaska: Alaska Dept. Health and Welfare Hydrol. Data Rept. 7, 10 p.

$-1960 \mathrm{a}$, Ground-water conditions in the vicinity of Project Chariot, Ogotoruk Creek, northwestern Alaska, in Kachadoorian, Reuben, and others, 1960, Geologic investigations in support of Project Chariot in the vicinity of Cape Thompson, northwestern Alaska-Preliminary report p. 72-75: Atomic Energy Commission, Tech. Inf. Service, TEI-753, 94 p.

$1960 \mathrm{~b}$, Winter ground-water investigations in the vicinity of Cape Thompson, Alaska, in Kachadoorian, Reuben, and others, 1960, Supplemental report on geologic investigations in support of Phase II, Project Chariot in the vicinity of Cape Thompson, northwestern Alaska, p. 29-30: U.S. Geol. Survey open-file report (TEI-764), $30 \mathrm{p}$.

-1961a, Summary of ground-water conditions in Alaska as they affect private water supplies: Alaska Dept. Health and Welfare Hydrol. Data Rept. 11, 3 p.

$-1961 \mathrm{~b}$, Ground-water investigations in support of Project Chariot, Phase III-summer 1960, in Kachadoorian, Reuben, and others, 1961, Geologic investigations in support of Project Chariot, Phase III, in the vicinity of Cape Thompson, northwestern Alaska-Preliminary report, p. 87-101: U.S. Geol. Survey open-file report (TEI-779), $104 \mathrm{p}$.

1962, Winter hydrology of a small Arctic stream (abs.) in Alaskan Sci. Conf., 12th, College 1961, Proc.: Sci. Alaska 1961, p. 134-136.

1963, Alaska: U.S. Geol. Survey Water-Supply Paper 1760, p. 3-12. 
1966, Ground-water hydrology: reprint from Environment of the Cape Thompson Region, Alaska, chap. 7, p. 115-124, Atomic Energy Commission, Div. of Tech. Inf.

Waller, R. M., Feulner, A. J., and Tisdel, F. E., 1962 Ground-water movement in the Fort Greely area, Alaska (abs.), in Alaskan Sci. Conf., 12th, College 1961, Proc.: Sci. Alaska 1961, p. 133-134.

Waller, R. M., and Mathur, S. P., 1962, Data on water supplies at Nome, Alaska: Alaska Dept. Health and Welfare Hydrol. Data Rept. 17, 12 p.

Waller, R. M., and Selkregg, L. F., 1962, Data on wells and springs along the Glenn Highway (State 1), Alaska: Alaska Dept. Health and Welfare Hydrol. Data Rept. $15,23 \mathrm{p}$.

Waller, R. M., and Tolen, D. A., 1962a, Data on wells along the Alaska Highway (State 2), Alaska: Alaska Dept. Health and Welfare Hydrol. Data Rept. 18, 26 p.

1962b, Data on wells and springs along the Richardson Highway (State 4), Alaska: Alaska Dept. Health and Welfare Hydrol. Data Rept. 16, 30 p.

Waring, G. A., 1917, Mineral springs of Alaska, with a chapter on the chemical character of some surface waters of Alaska, by R. B. Dole and A. A. Chambers: U.S. Geol. Survey Water-Supply Paper 418, 118 p.

Werenskiold, W., 1922, Frozen earth in Spitsbergen: Geofys. Publikationer, v. 2, no. 10, 10 p.

1953, The extent of frozen ground under the sea bottom and glacier beds: Jour. Glaciology, v. 2, no. 13, p. 197-200.

Wernecke, Livingston, 1932, Glaciation, depth of frost, and ice veins of Keno Hill and vicinity, Yukon Territory [Canada] : Eng. Mining Jour., v. 133, no. 1, p. 38-43.

Williams, J. R., 1959, Geology of the western part of the Big Delta (D-6) quadrangle, Alaska: U.S. Geol. Survey Misc. Geol. Inv. Map I-297.

1960, Cenozoic sediments beneath the central Yukon Flats, Alaska, in Short papers in the geological sciences: U.S. Geol. Survey Prof. Paper 400-B, p. B329.

1962, Geologic reconnaissance of the Yukon Flats district, Alaska: U.S. Geol. Survey Bull. 1111-H, p. 289-331.

1965 , Ground water in permafrost regions; an annotated bibliography: U.S. Geol. Survey Water-Supply Paper 1792, $294 \mathrm{p}$.

1970 , a review of water resources in the Umiat area, northern Alaska: Geol. Survey Circ. 636. (In press).

Williams, J. R., Péwé, T. L., and Paige, R. A., 1959, Geology of the Fairbanks (D-1) quadrangle, Alaska: U.S. Geol. Survey Geol. Quad. Map GQ-124.

Williams, J. R., and Waller, R. M., 1965, Ground-water occurrence in permafrost regions of Alaska: Internat. Conf. on Permafrost, Lafayette, Ind., 1963, Proc., p. 159-164.

Zubov, N. N., 1959, Predel'naia tolshchina meterikovykh l'dov (Limiting thickness of continental ice) : Priroda, v. 48 , no. 3, p. 88-90. 
